
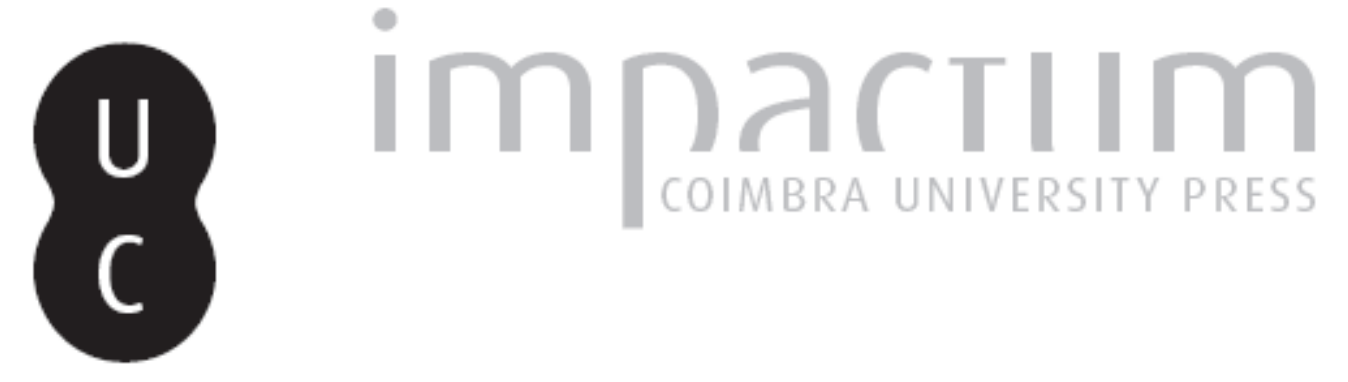

\title{
Peças glípticas de Conimbriga
}

\section{Autor(es): $\quad$ Cravinho, Graça}

Publicado por: Imprensa da Universidade de Coimbra

URL persistente:

URl:http://hdl.handle.net/10316.2/45361

DOI:

DOI:https://dx.doi.org/10.14195/1647-8657_40_5

Accessed : $\quad$ 26-Apr-2023 01:09:28

A navegação consulta e descarregamento dos títulos inseridos nas Bibliotecas Digitais UC Digitalis, UC Pombalina e UC Impactum, pressupõem a aceitação plena e sem reservas dos Termos e Condições de Uso destas Bibliotecas Digitais, disponíveis em https://digitalis.uc.pt/pt-pt/termos.

Conforme exposto nos referidos Termos e Condições de Uso, o descarregamento de títulos de acesso restrito requer uma licença válida de autorização devendo o utilizador aceder ao(s) documento(s) a partir de um endereço de IP da instituição detentora da supramencionada licença.

Ao utilizador é apenas permitido o descarregamento para uso pessoal, pelo que o emprego do(s) título(s) descarregado(s) para outro fim, designadamente comercial, carece de autorização do respetivo autor ou editor da obra.

Na medida em que todas as obras da UC Digitalis se encontram protegidas pelo Código do Direito de Autor e Direitos Conexos e demais legislação aplicável, toda a cópia, parcial ou total, deste documento, nos casos em que é legalmente admitida, deverá conter ou fazer-se acompanhar por este aviso. 
UNIVERSIDADE DE COIMBRA

FACULDADE DE LETRAS

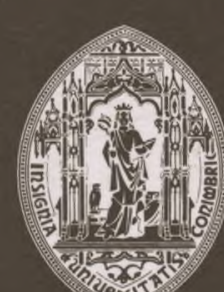

CONIMBRIGA

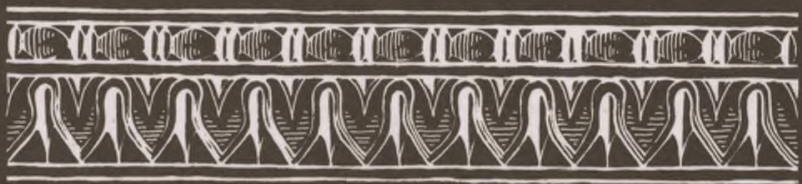

VOLUME XL - 2001 


\title{
Graça Cravinho
}

Mestre em História da Arte. Estudante de Doutoramento em Arqueologia e História da Antiguidade, na Universidade de Santiago de Compostela. Bolseira da Fundação para a Ciência e a Tecnologia, ao abrigo do Programa PRAXIS XXI

\author{
PEÇAS GLÍPTICAS DE CONIMBRIGA \\ "Conimbriga" XL (2001) p. 143-199
}

Resumo: Após uma primeira abordagem numa Tese de Mestrado em História da Arte, apresentada pela autora à Faculdade de Ciências Sociais e Humanas da Universidade Nova de Lisboa (sob a orientação do Professor Doutor Bairrão Oleiro, a cuja memória é dedicado o presente artigo) e num trabalho de investigação, apresentado pela autora à Universidade de Santiago de Compostela, no âmbito do Curso de Doutoramento (sob a orientação da Professora Doutora Raquel Casal Garcia, cujo apoio é de enaltecer), pretende-se fazer um estudo completo e actualizado das pedras de anel encontradas em Conimbriga. Por um lado, porque os anteriores, para além de sucintos e com algumas imprecisões, estão dispersos por várias publicações. Por outro, porque outras peças surgiram desde então: um anel inédito e três moldes de entalhes encontrados no Séc. XIX, recentemente oferecidos ao Museu de Conimbriga.

Abstract: Avec cet article, basé sur un mémoire de Maîtrise en Histoire de l'Art, que j'ai présenté à la Faculté de Sciences Sociales et Humaines de l'Universidade Nova de Lisboa (sous l'orientation du Professeur Docteur Bairrão Oleiro, à la mémoire de qui je dédie cette étude) et sur un travail de recherche, que j'ai présenté à l'Université de SaintJacques de Compostele, dans le cadre des Cours de Doctorat de cette Université-là (sous l'orientation de la Professeur Docteur Raquel Casal Garcia, que je remercie de son enseignement), on a prétendu 
faire une étude complète et actualisée des pierres de bagues gravées trouvées à Conimbriga. Les études antérieures sont, en effet, non seulement dispersées dans plusieurs publications, mais elles sont aussi succintes et susceptibles de quelques remarques. On a étudié, en outre, une pierre de bague inédite e trois moules d'intailles trouvées au $X^{X}{ }^{\text {eme }}$ Siècle, qui ont été offerts au Musée de Conimbriga.

Conimbriga, 40 (2001) 141-197 


\section{PEÇAS GLÍPTICAS DE CONIMBRIGA}

A Mário Cardozo se deve o primeiro estudo de síntese sobre peças glípticas romanas encontradas no actual territorio português ${ }^{1}$. Contudo, apesar do reduzido número que nele recolhia, mencionava já alguns entalhes de Conimbriga, provenientes de escavações antigas (n. ${ }^{\circ} \mathrm{s} 5,9,14,16$, 19 e 22 do Catálogo que se segue) ou de achados fortuitos (n. ${ }^{\circ} 10$ ). Alguns deles voltariam a ser referidos por Elsa Ávila de Sousa que, em 1969, lhes acrescentava mais três (n. ${ }^{\circ} \mathrm{s}$ 6, 7 e 8) ${ }^{2}$. Com as campanhas luso-francesas, novos exemplares seriam trazidos à luz do dia (n. ${ }^{\circ} \mathrm{s} 1,2$, $3,4,11,12,13,17$ e 21)3. Finalmente, junto e dentro de duas domus (a "Casa dos Esqueletos" e a "Casa de Cantaber", respectivamente), escavadas há várias dezenas de anos, apareceriam dois anéis com pedras gravadas (n. ${ }^{\circ} \mathrm{s} 20$ e 18). Mas, à falta de qualquer registo, está ainda por esclarecer como e quando foi encontrado o entalhe $n .^{\circ} 15$, a que talvez se refira já Elsa Ávila de Sousa, a propósito do n. ${ }^{\circ} 19$.

Não há também notícia do achado de joias valiosas na cidade e são raros os objectos em ouro e prata dela exumados. Mesmo assim, alguns dos entalhes encontrados (ou moldes que deles restam) revelam uma certa delicadeza de execução.

As suas formas não diferem muito das que vemos por todo o Império, em geral, e no nosso país, em particular, já que há uma clara predominância das pedras ovais e de faces planas. Apenas os $\mathrm{n} .{ }^{\circ} \mathrm{s} 3,8$, 22 (circulares) e 20 (rectangular) constituem excepção.

Quanto à sua natureza, o primeiro gráfico da fig. 1 mostra-nos a abundância de exemplares em pasta vítrea. Por razões de ordem

1 CARdozo, Mário, "Pedras de Anéis Romanos Encontradas em Portugal".

Revista de Guimarães, LXXII, n. ${ }^{\circ}$ s 1-2, p. 155-160. Guimarães, 1962.

${ }^{2}$ FrANÇA, Elsa Ávila, "Anéis, braceletes e brincos de Conimbriga". Conimbriga, VIII. Coimbra, 1969, p. 17-43.

${ }^{3}$ Alarcão, J.; Etienne, R.; Alarcão, A. e Ponte, S., Fouilles de Conimbriga, vol. VII, p. 133-139. Paris, 1979.

Conimbriga, 40 (2001) 141-197 
económica? De facto, ela poderá ser um reflexo da existência de uma população de parcos recursos, que recorria às imitações para também sentir o prazer de usar joias adornadas com gemas. Mas, não podemos nunca esquecer que, por vezes, o seu uso está intimamente ligado a questões de moda, como aconteceu nas épocas de César e de Augusto. Estão nesse caso os n. $^{\circ} \mathrm{s} 1,2,3,4$ e 7, de cronologia mais recuada. Mas, talvez os dados pudessem ser ligeiramente diferentes se tivesse ficado registada a natureza de três entalhes, encontrados no século XIX, e hoje apenas conhecidos pela doação recente, ao Museu, dos seus moldes em lacre (n. ${ }^{\circ} \mathrm{s} 23,24$ e 25) e de um outro, publicado por Mário Cardozo, de que apenas resta a gravura que nos deixou (n. $\left.{ }^{\circ} 22\right)$.

Relativamente aos temas, e à semelhança também do restante país e Império, sobressaem os de carácter mitológico, como facilmente se depreende da análise do segundo gráfico da mesma figura. Entre as divindades, merecem especial destaque as três representações de Mercúrio ( $\mathrm{n} .^{\circ} \mathrm{s} 11,12$ e 23). Porquê? Porque nesta cidade o deus tenha sido objecto de um culto especial? Ou elas serão indício da sua actividade comercial? Ou fruto de mera casualidade de achado? $\mathrm{E}$ as pedras em que vemos Marte (n. ${ }^{\circ}$ 9), o herói ferido (n. ${ }^{\circ}$ 2) e o eventual Teseu (n’ 16), teriam pertencido a guerreiros? Já a de Athena Nikephoros (n. $\left.{ }^{\circ} 10\right)$ poderia ter sido usada por um guerreiro que, assim, quis perpetuar uma vitória ou por alguém mais votado às coisas do espírito e da Ciência. Por sua vez, a que tem gravado um Erote $\left(n .{ }^{\circ}\right)$ poderia ter pertencido a uma jovem, o gryllos (n. ${ }^{\circ}$ 8) a alguém supersticioso e a do molde com um atleta segurando a coroa de louros (n. $\left.{ }^{\circ} 25\right)$ a um atleta vencedor.

Se passarmos em revista os entalhes com motivos animalistas (n. ${ }^{\circ}$ s 5, 6, 17, 18 e 19), verificamos que predominam os de carácter bucólico. De realçar, a presença do cavalo - um dos animais mais comummente representado em gemas, no nosso território ${ }^{4}$. Talvez que nesse espírito de aurea mediocritas pudéssemos também incluir o exemplar que tem gravado Faustulus (n. $\left.{ }^{\circ} 4\right)$. Se bem que, em certos casos, essa representação tenha mais a ver com a necessidade de manter bem viva a lenda da fundação de Roma. Sobretudo, entre povos recém-conquistados...

${ }^{4}$ Não podemos esquecer, por um lado, que a Península Ibérica era uma das regiões produtoras de cavalos destinados a espectáculos circenses e, por outro, que era natural da Lusitânia um famoso auriga de Roma.

Conimbriga, 40 (2001) 141-197 
Mas, até que ponto a existência do peixe (n. ${ }^{\circ}$ 19) não poderá ser indício de cristianização da cidade?

Uma ajuda preciosa para o estabelecimento destas relações entre os temas gravados e os proprietários das gemas tem sido o estudo de corpos encontrados na região das termas suburbanas de Herculanum, perto da saída para o mar. Fugindo à erupção do Vesúvio, de 79 d. C., nos seus dedos figuravam ainda os anéis que, no momento, usavam ou queriam salvar 5 .

Por outro lado, haverá também alguma explicação para o achado de entalhes em zonas determinadas das cidades? ${ }^{6}$ É frequente o seu aparecimento em termas, sejam elas privadas ou públicas - ao que parece, um local privilegiado para os frequentadores perderem as pedras dos seus anéis, soltas por acção das águas... Curiosamente, em Conimbriga, duas provêm das Termas de Trajano — uma, com a representação de Mercúrio (n. $\left.{ }^{\circ} 11\right)$, foi encontrada perto do praefurnium do laconicum; outra, com a de Faustulus (n. ${ }^{\circ}$ ), numa canalização ${ }^{7}$.

Finalmente, sob o ponto de vista cronológico, verificamos que a maioria se situa entre os Séculos I e III d. C. Todavia, há a assinalar uma situação problemática: a do entalhe n. ${ }^{\circ} 11$, engastado num anel em prata com aro de secção em D. Datável, normalmente, de finais do Séc. II d. C., este tipo de anéis aparece já, em Conimbriga, em horizontes de Cláudio e de Trajano... ${ }^{8}$ Como explicar este facto? É um problema que se mantém em aberto.

Pequeninas obras de arte, estas peças glípticas são, na realidade, uma importante fonte para o estudo da Romanização da cidade. Tal como os monumentos, as casas, as inscrições, também elas nos falam da economia, das diferenças sociais, da cultura, do sentido estético e das crenças mágico-religiosas dos que a habitaram.

5 Vide, a propósito: GuIRAUD, H. (1996), Intailles et Camées romains, p. 173.

6 Sobre esta problemática, vide op. cit., p. 164-166.

7 Um entalhe com a representação de Mercúrio foi também encontrado num esgoto das termas de Augst (op. cit., p. 166).

8 Vide: Alarcão, A. M. e PONTE, S., 1984, p. 91. 


\section{CATÁlogo}

I - ENTALHES:

A - Período Augustano

19

Séc. I a. C.

Natureza: pasta vítrea; Cor: cor de mel, escurecida pela patine

Forma: oval alargada (engastado num fragmento de anel em bronze ${ }^{9}{ }^{10}$ )

Mesa: plana; Dimensões: $8 \mathrm{~mm}$ X $10 \mathrm{~mm}^{11}$

Estado de conservação: bom; Número de inventário: 67.18

Motivo:

\section{EROS SOBRE LEÃO}

Eros montando um leão, de perfil para a esquerda ${ }^{12}$. Com a longa cauda erguida, o leão levanta a pata dianteira direita e olha atentamente para uma serpente que se eleva na sua frente. Linha de solo. Na base do motivo, teria estado um modelo gravado pela "técnica de pontitas", de estilo etruscanizante.

\section{Paralelos: 13}

Ammaia (Aramenha), inédita

Salona, Middleton, S. H. (1991), p. 65-66, n. ${ }^{\circ} 79$ (segurando rédeas ou tocando flauta)

9 A catalogação dos entalhes, quer republicanos quer imperiais, é feita cronologicamente e pela seguinte ordem de tipos: divindades, heróis, figuras humanas, animais, objectos simbólicos, grylloi, inscrições e motivos não identificados. No final, é apresentado o estudo dos três moldes já citados.

10 Encontrado em 1967, no nível cláudio da construção da insula a norte das

Termas, durante as escavações luso-francesas.

11 As dimensões indicadas nos entalhes engastados em anéis correspondem à sua parte visível.

12 Na descrição das figuras, as expressões "voltado/a à esquerda" ou " à direita" têm a ver com o observador.

13 Nos paralelos, é primeiramente indicado o local de achado das peças, por ordem crescente de distância a partir da Lusitânia (primeiro na Europa e depois nos continentes africano e asiático). Se a sua proveniência for desconhecida, indica-se o seu paradeiro actual (museu ou coleç̧ão particular) ou aquele que é referido pela bibliografia que os cita. Caso não haja quaisquer elementos de localização (por não serem indicados na bibliografia ou não ter sido possível colhê-los), será posta uma interrogação antes da referência bibliográfica.

Conimbriga, 40 (2001) 141-197 
Gadara, HeNIG-Whiting (1987), p. 20, n. ${ }^{\circ} 179$ (empunhando coroa)

Haia, MAASKANT-KLEIBRINK, M. (1978), p. 368, n. ${ }^{\circ} 1160$ (empunhando chicote)

Florença, Furtwàngler, A. (1900), p. 159, est. LVII, n. ${ }^{\circ} 1$ (tocando $^{2}$ cítara).

Eros-Cupido, o deus do Amor (em particular, o erótico e romântico), de personalidade instável e uma força eternamente insatisfeita e inquieta, era na Mitologia Greco-Romana a força fundamental do Mundo, já que assegurava a continuidade das espécies e a coesão interna do Cosmos. Frequentemente representado com os olhos vendados (porque o amor é, muitas vezes, cego), tinha, como armas, dardos ou setas cujas pontas haviam recebido um tratamento mágico, produzindo, assim, ou um amor incontrolável ou um desinteresse invencível pela primeira pessoa que a sua vítima visse, depois de atingida.

Já no Século V a. C., era representado em brincos e anéis gregos. Em brincos continuaria, aliás, a ser frequente, no Sul de Itália, ao longo dos Séculos III e II a. C. Sob a influência dos poetas alexandrinos, porém, foi assumindo a forma de uma criança, geralmente alada, que ora brinca, ora se delicia a inflamar Psyche com a sua tocha ou a fazer sangrar corações com as suas flechas. E um vasto reportório, de origem helenística, que procura retratar a vida deste frágil deus, cujos poderes, contudo, homens e deuses temiam e que à própria mãe ${ }^{14}$ inspirava respeito. É que, por debaixo da sua figura inocente, escondia-se um deus poderoso, que podia desferir golpes cruéis.

$\mathrm{Na}$ Arte Romana, a sua representação remonta aos finais da República, tanto em pinturas murais e esculturas oficiais como na decoração de sarcófagos. Em Glíptica, viria mesmo a constituir um dos motivos mais frequentes. Inclusive no actual território português, a julgar pelo número de entalhes e camafeus, até à data, encontrados ${ }^{15}$ e que, tal como a inscrição do Sobrado e um exemplar escultórico, encontrado na villa de Cardílio, atestam o seu culto nesta região da Lusitânia. Sozinho, com outras divindades ou com animais (reais ou míticos), surge-nos numa variedade de poses e atributos (por vezes, mesmo, de outros deuses), caricatural ou jocoso, com elementos fantásticos ou da vida quotidiana. Aliás, essa infinidade de tipos não é senão, segundo Raquel Casal Garcia (1979, p. 1115-1116), uma forma de expressar a multiplicidade dos estados de alma do próprio Amor - ora ardente, ora brincalhão, ora triste, ora louco.

14 Afrodite-Vénus, segundo determinadas versões da mitologia.

15 Em dois desses exemplares (um na Biblioteca Nacional de Lisboa e outro na posse de um particular), Eros-Cupido queima Psyche com uma tocha acesa (CRAVINHO, G., 1997-1998, n. 7 e CrAVINHO, G., 2000, est. I, n. ${ }^{\circ}$ 1, respectivamente).

Conimbriga, 40 (2001) 141-197 
Bastante comum é a representação de Cupido montando animais, reais ou míticos ${ }^{16}$. Quando monta um leão, como no entalhe acima descrito, estamos perante um tema ligado ao thiasus dionisíaco, igualmente presente noutras formas de arte.

Mas, pode montar outros animais, como o cavalo - um motivo cuja popularidade é atestada pelo grande número de exemplares em que aparece gravado ${ }^{17}$. Assim o vemos numa pequena cornalina alaranjada $(9 \times 11$ x 2,2), de faces planas, polidas e com os bordos cortados para dentro, datável do Séc. I d. C. e proveniente de Coimbra ${ }^{18}$. Em certos casos, porém, Cupido apresenta atributos diversificados ou é ladeado por um segundo cavalo, cujas rédeas segura $^{19}$, ou acompanhado por um segundo Erote empunhando uma palma ${ }^{20}$ ou uma palma e uma $\operatorname{coroa}^{21}$ (o que o identifica como cavaleiro vencedor) ou caminhando à sua frente, segurando as rédeas do seu cavalo 22 .

Bastante frequente é, também, a sua representação montando a cabra ${ }^{23}$ (um tema que aparece já em denários de 85 a. C., cunhados por M. Fonteius ${ }^{24}$ ), o camelo $^{25}$, o carneiro $^{26}$ ou a pantera ${ }^{27}$ (uma outra variante com conotação dionisíaca).

16 Em muitos casos, monta o centauro, o hipocampo ou o capricórnio. Noutros, animais marinhos, como o golfinho - tema que deveria ter um significado funerário, já que Eros era tido como o condutor das almas para as ilhas dos Bem Aventurados. $\mathrm{O}$ que explica a sua frequente representação em sarcófagos, onde irá persistir mesmo no período cristão.

17 Sena Chiesa, G., 1966, n. ${ }^{\circ}$ 330; Krug, A., 1978, n. ${ }^{\circ}$ 6; Henig, M., 1974, n. ${ }^{\circ}$ 109-110; 126; 736; RichteR, G., 1971, n. ${ }^{\circ} 162$; MARShall, F. H., 1907, n. ${ }^{\circ} 371$, fig. 75; BoARDMAN, J., 1968, n. ${ }^{\circ}$ 61; MAASKANT-KLEIBRINK, M., 1978, n. ${ }^{\circ}$ 901; NeVerov, O., 1988, n. ${ }^{\circ}$ 49; SPIER, J., 1992, n. ${ }^{\circ}$ s 321 e 362; FurTWÀNGLER, A., 1900, est. XXXV, n. ${ }^{\circ} 28$.

18 Foi encontrada no pátio da Universidade, em escavações recentes, efectuadas sob a direç̧ão da Professora Doutora Helena Catarino que, muito gentilmente, facultou o seu estudo.

19 Middleton, S. H., 1991, n. ${ }^{\circ} 80$.

20 LIPPOLD, G., 1922, est. CXXIII, n. ${ }^{\circ} 2$.

21 MaAsKant-KleibrinK, M., 1978, n. ${ }^{\circ} 903$.

22 BERRY, B., 1969, n. ${ }^{\circ} 128$.

23 SPIER, J., 1992, n. ${ }^{\circ}$ 419; GuIRAUd, H., 1996, n. ${ }^{\circ}$ 5; Guiraud, H., 1988, n. ${ }^{\circ}$ S 336-337; Marshall, F. H., 1907, n. ${ }^{\circ}$ 513; Casal Garcia, R., 1991, n. ${ }^{\circ}$ s 50 e 264; ZWierlein-Diehl, E., 1991, n. ${ }^{\circ}$ 2540/40; IMHOOF-Blumer, F. e Keller, O., 1972, est. XVIII, n. ${ }^{\circ} 18$.

24 Citação de SPIER, J., 1992, p. 150.

25 Sena Chiesa, G., 1966, n. ${ }^{\circ}$ 329; Richter, G., 1971, n. ${ }^{\circ}$ 163; MAaskant-KleibrinK, M., 1978, n. ${ }^{\circ}$ 826; LipPOLD, G., 1922, est. XXVIII, n. ${ }^{\circ}$ 7; FurTWÀngLER, A., 1900, est. XLII, n. ${ }^{\circ} 49$.

Conimbriga, 40 (2001) 141-197 


\section{Bibliografía:}

Alarcão, J.; Etienne, R.; Alarcão, A. e Ponte, S., Fouilles de Conimbriga, vol. VII, p. 135 e 138, n. ${ }^{\circ}$ 185, est. XXXII, 185. Paris, 1979.

Natureza: pasta vítrea, imitando ágata de bandas; Cor: verde, azul e branco

Forma: oval (engastado num fragmento de anel em bronze ${ }^{29}$ )

Mesa: plana; Dimensões: $12,5 \mathrm{~mm}$ X $8 \mathrm{~mm}$

Estado de conservação: bom; Número de inventário: 69.379 Motivo.

\section{HERÓI FERIDO}

Guerreiro despido, voltado à direita, com o corpo ligeiramente a três quartos. Ostentando na cabeça um elmo e, enfiado no braço direito, um escudo oval com umbo central, apoia no solo o joelho direito. Não há linha de solo.

\section{Paralelos:}

Luni, Sena Chiesa, G. (1978), p. 51, est. I, n. ${ }^{\circ} 3$

Colónia, Krug, A. (1980), p. 183, est. 73, n. ${ }^{\circ} 57$

Brechin, FurtwÂngler, A. (1900), p. 125, est. XXV, n. ${ }^{\circ} 6$

Roma, RighetTi, R. (1955), p. 20, n. ${ }^{\circ} 35$

Cambridge, middleton, J. H. (1969), pi. II, n. ${ }^{\circ} 36$, Ap. XIII-XIV

Haia, MaAsKant-Kleibrink, M. (1978), p. 96, n. ${ }^{\circ} 62 ;$ p. 187, n. ${ }^{\circ} 404$

Berlim, Furtwângler, A. (1900), p. 114, est. XXIII, n. ${ }^{\circ} 30$

?, Reinach, S. (1895), est. 62, n. ${ }^{\circ}$ 58.4.

O tipo acima descrito, baseado no do kanapeus e inspirado, provavelmente, num episódio histórico ou lendário, tem na sua origem modelos gregos dos Séc. $\mathrm{V}^{30}$ e IV a. C. ${ }^{31}$, helenísticos e escaravelhos etruscos dos Séc. IV-III a. C. ${ }^{32}$.

26 ImHOOF-Blumer, F. e Keller, O., 1972, est. XVIII, n. ${ }^{\circ} 51$.

27 MaASKant-KleibrinK, M., 1978, n. ${ }^{\circ} 374$; KRUG, A., 1980, n. ${ }^{\circ} 133$.

28 Esta cronologia tem em conta o tipo de pasta vítrea (cf. MAIOLI, M. G., 1971, n. ${ }^{\circ} 25$ e Guiraud, H., 1988, n. ${ }^{\circ} 531$ e 817), muito popular na época de Augusto (cf. CASAL GARCIA, R., 1991, n. ${ }^{\circ}$ s 275 e 313 ).

29 Encontrado em 1969, nas Termas de Trajano, durante as escavações luso-francesas.

30 BOARDMAN, J., 1975, n. ${ }^{\circ} 9$.

31 NeVEROV, O., 1976, n. ${ }^{\circ} 45$.

32 Botrdman, J., 1968, n. ${ }^{\circ}$ 9; Middleton, S. H., 1991, n. ${ }^{\circ} 3$ - Ap. 
Com o herói apoiado no escudo (ou tendo-o ao ombro), empunhando lança ou espada e ostentando elmo, é um tipo que se insere no tema do "guerreiro ferido", bastante comum em gemas romanas de tradição etruscanizante e de que foram feitas numerosas réplicas, sobretudo em pasta vítrea. $\mathrm{Na}$ maior parte dos casos, o guerreiro, com um joelho em terra, olha em frente. Assim o vemos já em certos escaravelhos ${ }^{33}$ e assim aparece neste entalhe de Conimbriga. Noutros, porém, ele está de cabeça baixa, como que contorcendo-se com dores $^{34}$ (um motivo cujos antecedentes devemos também buscar em escaravelhos etrus $\cos ^{35}$ ) ou de cabeça erguida ${ }^{36}$ e apoiando-se no escudo, colocado ao alto, à sua frente ${ }^{37}$. Mais raramente, há na sua frente um vexillum, apoiado num pilar ao qual se encosta um segundo escudo ${ }^{38}$. Ou existe uma ave associada à cena ${ }^{39}$. Ou, com o manto pelas costas e resguardando-se com o escudo, tem na frente uma videira com cachos de uvas pendentes ${ }^{40}$.

Contudo, em certos exemplares, tem ambos os joelhos em terra (a postura típica do kanapeus)^. Noutros, agachado ou sentado, protege-se com o escudo $^{42}$, apoia-se nele ${ }^{43}$ ou está rodeado das suas armas ${ }^{44}$.

\section{Bibliografía:}

alarcão, J.; etienne, R.; Alarcão, A. e Ponte, S., Fouilles de Conimbriga, vol. VII, p. 135 e 138, n. ${ }^{\circ}$ 186, est. XXXII, 186. Paris, 1979.

Natureza: pasta vítrea imitando ágata de capas

Cor: castanho-escuro, na camada inferior, e verde-azulado, na superior

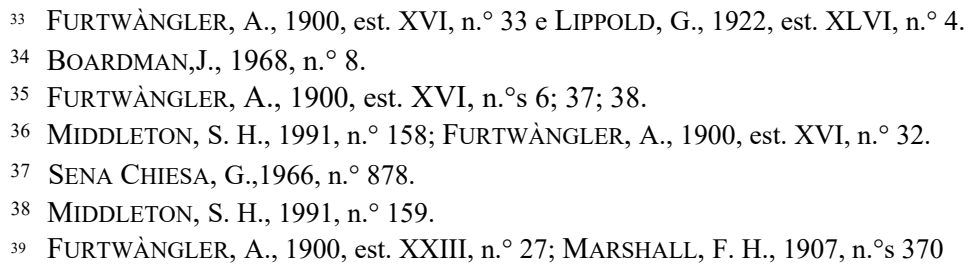
e 379 .

40 AstruC,M., 1954, n. $^{\circ} 39$.

ZAZOFF, P., 1965, n. ${ }^{\circ}$ 26; Guiraud, H., 1988, n. ${ }^{\circ}$ 469; Gauthier, M., 1977, p. 460, fig. 14 (interpretado como Aquiles); SENA ChIESA, G., 1966, n. ${ }^{\circ}$ 881; Middleton, S. H., 1991, n. ${ }^{\circ} 3-$ Ap.

42 RiCHTER, G., 1956, n. ${ }^{\circ} 440$.

43 Astruc, M., 1954, n. ${ }^{\circ}$ 50; Gramatopol, M., 1974, n. ${ }^{\circ} 473$.

44 Sena Chiesa, G., 1966, n. ${ }^{\circ} 880$. 
Forma: circular (engastado num fragmento de anel em prata ${ }^{45}$ ); Mesa: plana, sem sobressair do anel

Dimensões: $10 \mathrm{~mm}$ de diâmetro; Estado de conservação: com muita patine

Número de inventário: 64.113

Motivo:

\section{CASAL AFRONTADO}

Busto feminino, de perfil à esquerda, com penteado à moda de Octávia. Na sua frente, um busto masculino (Octávio? Marco António?).

\section{Paralelos:}

Haia, MaAsKant-Kleibrink, M. (1978), p. 371, n. $^{\circ} 1169$

Munique, Vollenweider, M.-L. (1972), p. 99, est. 154, n. ${ }^{\circ} 9$

Berlim, Vollenweider, M.-L. (1972), p. 99 , est. 154 , n. ${ }^{\circ} 15$

S. Petersburgo, Neverov, O. (1976), p. 70, n. ${ }^{\circ} 99$ (interpretado como Octávia e Octávio).

Tema comum em anéis ${ }^{46}$, moedas ${ }^{47}$ e gemas, a representação de um casal afrontado deveria simbolizar a harmonia do casal que, por vezes, parece mesmo beijar-se. Frequente, sobretudo, nos finais da República e inícios do Império, viria a constituir um motivo muito popular em Glíptica no Século II d. C. - altura em que se destacam as representações de Faustina Júnior e Marco Aurélio. E manter-se-ia sob o Cristianismo, como se depreende de um entalhe mais tardio em que, entre o casal, está gravado um cristograma ${ }^{48}$.

\section{Bibliografía:}

alarcão, J.; etienne, R.; alarcão, A. e ponte, S., Fouilles de Conimbriga, vol. VII, p. 135 e 138, n. ${ }^{\circ}$ 188, est. XXXII, 188. Paris, 1979.

45 Encontrado em 1964, nas escavações luso-francesas, no nível de construção da insula a oeste do forum. Datado de meados do Séc. I d. C., nele apareceu também uma moeda do Séc. I a. C. (denário de M. Acilius, de 49 a. C.).

46 Marshall, F. H., 1907, n. ${ }^{\circ} 1479$.

47 Cf. VOLlenweIDER, M.-L., 1972, p. 98-99, est. 153, n. ${ }^{\circ} 10$ e est. 154 , n. ${ }^{\circ}$ s 1 -7: dupondios cunhados em 37 a. C. (de Marco António e Calpurnius Bibulus), com a representação de Marco Antonio e Octávia; em 37-36 a. C. (de Marco Antonio e L. Sempronius Atratinus); em 37-36 a. C. (dupondios e tripondios de Marco Antonio e $M$. Oppius Capito); e em 36-35 a. C.

48NeVErov, O., 1976, n. ${ }^{\circ} 144$ (do Séc. IV d. C.).

Conimbriga, 40 (2001) 141-197 
Natureza: cornalina; Cor: alaranjada, com uma incrustação negra no lado esquerdo

Forma: oval; Faces: planas, com os bordos cortados para dentro

Dimensões: $8 \mathrm{~mm}$ X 10,5 mm X 2,2 mm; Estado de conservação: bom Número de inventário: 69.382

Motivo:

\section{CENA PASTORIL}

Pastor ajoelhado, de perfil para a esquerda, sob uma árvore cujos ramos acompanham o contorno da pedra. Ostentando chapéu e apenas com uma pele de animal sobre as costas, do tipo Faustulus, ordenha uma cabra que para si volta a cabeça. Atrás, inclinado, o pedum. Linha de solo.

\section{Paralelos:}

Italica, LOPEZ DE LA ORden, M. D. (1989), p. 253, n. ${ }^{\circ} 21$, est. II, n. ${ }^{\circ} 21$; LOPEZ DE LA ORden, M. D., (s. d.), p. 156, n. ${ }^{\circ} 151$, est. XIV, n. ${ }^{\circ} 151$

Béthune, Guiraud, H. (1988), p. 159, est. XLII, n. ${ }^{\circ} 609$

Aquileia, Sena ChiesA, G. (1966), p. 292, est. XL, n. 789

Magna Grécia (sic), Marshall, F. H. (1907), p. 74, n. ${ }^{\circ} 416$

Bath, Henig, M. (1974), p. 72, n. ${ }^{\circ} 503$

Cesareia, Hamburger, A. (1968), p. 36, est. VII, n. ${ }^{\circ} 148$

Gadara, Henig, M. e Whiting, M. (1987), p. 30, n. ${ }^{\circ} 294$

Madrid, CASAl Garcia, R. (1991), p. 160, n. 362

Haia, MaAsKant-KLeibrinK, M. (1978), p. 313, n. ${ }^{\circ} 925$

Viena, ZWeirlein-Diehl, E. (1991), p. 59, est. $11, \quad$ n. ${ }^{\circ} \mathrm{s} 1668 ; 1670$

Kassel, Zazoff, P. (1965), p. 63-64, n. ${ }^{\circ}$ 31, est. 10,n. ${ }^{\circ} 31$

Paris, Imhoof-Blumer, L. e Keller, O. (1972), p. 112, n. ${ }^{\circ} 10$, est. XVIII, n. ${ }^{\circ} 10$

Tunis, Hautecoeur, M. L. (1910), p. 345, n. ${ }^{\circ} 100$.

A representação artística de cenas pastoris (derivada da iconografia helenística e tema de pinturas de natureza paisagística, desde a segunda metade do Séc. I a. C. até à época de Augusto) se, por um lado, teria como objectivo a valorização da vida simples e repousante dos ambientes rurais (a aurea mediocritas) por outro, pretendería simbolizar Faustulus, o pastor que recolheu Romulo e Remo. Contudo, em Glíptica, ela predomina entre os Séculos II e I a. C. e na primeira metade do Séc. I d. C., o que nos faz pensar num terceiro ${ }^{49}$

${ }^{49}$ Encontrado em 1969, nas escavações luso-francesas, numa canalização das Termas de Trajano.

Conimbriga, 40 (2001) 141-197 
objectivo, agora de natureza política: a transmissão da ideia de felicidade tranquila trazida pelo governo de Augusto. Tal como o aparecimento de Faustulus, nos cunhos monetários de Vespasiano, seria uma forma de propaganda política pela alusão clara ao seu programa agrícola para a Itália.

De entre todas as cenas pastoris, a mais frequente em gemas (tal como em moedas, mosaicos e sarcófagos, tanto pagãos como cristãos), é a do pastor ordenhando uma cabra - seja ele Faustulus, um Erote, um Sátiro, um homem ou uma jovem ${ }^{50}$. E isso porque permaneceu durante muito tempo no reportório glíptico, não só pela importância que a cabra tinha na vida quotidiana de então (sobretudo, pelo leite) mas também pela sua associação à lenda da fundação de Roma.

O esquema mais popular talvez seja exactamente o que vemos neste entalhe. Mas, noutras variantes, Faustulus aparece sentado numa rocha ${ }^{51}$ (motivo também patente numa moeda de Vespasiano ${ }^{52}$ ) ou acompanhado de uma segunda cabra (deitada no solo ou trepando a uma árvore) e, em certos casos, ainda um cão ${ }^{53}$ ou três crias correndo ${ }^{54}$. Mais raramente, porém, a árvore não é representada e há uma duplicação da cena, num segundo plano ${ }^{55}$.

\section{Bibliografia:}

Alarcão, J.; Etienne, R.; Alarcão, A. e Ponte, S., Fouilles de Conimbriga, vol. VII, p. 135 e 139, n. ${ }^{\circ}$ 194, est. LIX, 4. Paris, 1979.

Natureza: ágata de capas concêntricas; Cor: castanho-âmbar, com veio intermédio azul

Forma: oval, com os bordos rectos desde a base até ao veio azulado

Faces: superior muito convexa e base plana; Dimensões: $9 \mathrm{~mm}$ X 11,5 $\mathrm{mm}$ X $4 \mathrm{~mm}$

Estado de conservação: bom; Número de inventário: A 426

so SENA ChiEsA, G., 1966, n..$^{\circ} 793$.

51 Richter, G., 1956, n. ${ }^{\circ}$ 451; MAASKANT-KLEIBRINK, M., 1978, n. ${ }^{\circ} 925$.

52 Citação de SENA ChIESA (1966, p. 292).

53 Richter, G., 1956, n. ${ }^{\circ}$ 450; SENA CHIESA, G., 1966, n. ${ }^{\circ} 788$; MAASKANTKLEIBRINK, M., 1978, n. ${ }^{\circ} 658$.

54 HENIG, M., 1975, n. $^{\circ} 200$.

55 ZWIERLEIN-DIEHL, E., 1991, n. ${ }^{\circ} 1667$.

56 Encontrado em escavações antigas, antes da criação do Museu de Conimbriga, onde deu entrada em Junho de 1962, fez parte do acervo do Museu Nacional Machado de Castro.

Conimbriga, 40 (2001) 141-197 


\section{Motivo:}

\section{CAVALO A GALOPE}

Cavalo correndo a galope, para a esquerda. Sob as patas traseiras, uma linha de solo.

\section{Paralelos:}

Corunha, Casal Garcia, R., 1977 (1979), p. 1116, n. ${ }^{\circ} 8$

Nages-et-Solorgues, Guiraud, H. (1988), p. 166, n. ${ }^{\circ} 669$

Bari, тамма, G. (1991), p. 34, n. ${ }^{\circ} 19$

$\boldsymbol{L} \boldsymbol{u n i}$, Sena Chiesa, G. (1978), p. 114, est. XVIII, n. ${ }^{\circ} 123$

Viena, Zwierlein-Diehl, E. (1991), p. 93, n. ${ }^{\circ} 1847$

Paris, imhoof-Blumer, F. e Keller, O. (1972), p. 101, est. XVI, n. ${ }^{\circ} 41$

Bucareste, gramatopol, M. (1974), p. 78, est. XXV, n. ${ }^{\circ} 508$.

Animal divino em certas regiões, como a Gália (por ser atributo de Epona), fundamental na guerra e na vida quotidiana de $\operatorname{Roma}^{57}$ e na própria construção do Império, o cavalo foi um dos motivos iconográficos mais difundidos, quer em gemas quer noutras formas artísticas - em sarcófagos, relevos (como nas colunas de Trajano e Marco Aurélio), estátuas equestres (como a de Marco Aurélio, no Capitólio), cabeças em bronze (caso das de M. Nonius Balbus e seu filho, provenientes de Herculano), mosaicos ${ }^{58}$, Arcos de Triunfo ${ }^{59}$ e gemas.

Algumas das peças glípticas que o retratam são bastante curiosas ${ }^{60}$. Contudo, o tipo em que é representado correndo a galope (presente já em moedas sicilianas e sarcófagos lícios, e muito comum em gemas greco-per$\operatorname{sas}^{61}$ e do Séc. V a. C. ${ }^{62}$ ) viria a ser um dos mais populares, sobretudo a partir do Séc. I a. C. Em certos exemplares, o cavalo parece mesmo ter-se liberto do cavaleiro que o montava, como o sugere uma rédea solta, esvoaçando ${ }^{63}$,

57 No campo de batalha e na confecção de elmos e cordas (para as máquinas de guerra), no primeiro caso. No segundo, como animal de tiro e montaria, auxiliar de caça e dos trabalhos agrícolas, para além da sua participação em cortejos triunfais, corridas e espectáculos aquáticos. Apenas em casos de fome extrema, era usado na alimentação.

58 Dos inúmeros exemplares conhecidos, destaquem-se os de Conimbriga, Piazza Armerina, Argélia, Tunísia e de Utica e Djemila, na Numidia.

59 A título de exemplo, citem-se os Arcos de Tito e de Constantino, em Roma, e o de Septimio Severo, em Leptis Magna, em que puxam quadrigas.

60 Middleton, S. H., 1991, n. ${ }^{\circ}$ 10; Guiraud, H., 1988, n. ${ }^{\circ} 661$; MARSHALl, F. H., 1907, n. ${ }^{\circ}$ s 382 e 1193; ZWIERLEIN-DIEHL, E., 1991, n. ${ }^{\circ}$ s 1836-1837.

61 MaAsKANT-KLEIBRINK, M., 1978, n. ${ }^{\circ} 18$.

62 NeVErov, O., 1976, n. ${ }^{\circ} 22$.

63 Krug, A., 1980, n. ${ }^{\circ} 409$; MAASKANT-KLEIBrinK, M., 1978, n. ${ }^{\circ} 410$; SENA 
ou há mesmo uma figura humana estendida sob as suas patas e segurando ainda a rédea (de certo, o cavaleiro tombado durante o galope) ${ }^{64}$.

Porém, noutros exemplares, o cavalo tem associados outros elementos: uma serpente sobre o dorso ${ }^{65}$ ou, mais frequentemente, uma coroa ${ }^{66}$ ou uma palma (presa na boca ou pousada nas costas) ${ }^{67}$. Nestes dois últimos casos, estamos perante um cavalo vencedor, assim imortalizado pelo seu dono. Motivo também comum em mosaicos (como, em Portugal, o "Mosaico dos Cavalos", na villa de Torre de Palma), em gemas irá ser muito frequente nos finais do Séc. II d. C. e no Séc. Ill d. C.

\section{Bibliografia:}

CARdozo, Mário. "Pedras de anéis romanos encontradas em Portugal". Revista de Guimarães, LXXII, n. ${ }^{\circ} \mathrm{s} 1$ e2,p. 155-160,n. ${ }^{\circ}$ 4. Guimarães, 1962

FrançA, Elsa Ávila. "Anéis, braceletes e brincos de Conimbriga". Conimbriga, VIII, p. 43, n. ${ }^{\circ} 5$, est. V, n. 5 (interpretado como "um pequeno quadrúpede"). Coimbra, 1969

Alarcão, A. M. e Ponte, S., Colecções do Museu Monográfico de Conimbriga - Catálogo, p. 95, n. ${ }^{\circ} 404.3$. (fig. na pág. 72, n. $^{\circ} 14$ - interpretado como um "pequeno veado"). Coimbra, 1984

Alarcão, Adília Moutinho. Museu Monográfico de Conimbriga Colecções, p. 131, n. 404.3 (interpretado como um "pequeno veado"). Instituto Português de Museus, Lisboa, 1994.

Natureza: ágata de bandas; Cor: castanho-escuro, com veio branco central

Forma: oval; Faces: planas, com os bordos cortados para dentro

Dimensões: 9,8 mm X 13,5 mm X 3 mm; Estado de conservação: bom

Número de inventário: A 425

Chiesa, G., 1966, n. ${ }^{\circ}$ s 1068-1069; Sena Chiesa, G., 1978, n. ${ }^{\circ}$ 122; ZWIERLeIN-DieHL, E., 1991, n. ${ }^{\circ} 1846$; TAMMA, G., 1991, n. ${ }^{\circ} 18$.

${ }^{64}$ ZWIERLEIN-DieHL, E., 1991, n. ${ }^{\circ} 1710$.

65 SENA ChIESA, G., 1966, n. ${ }^{\circ} 1216$.

66 MidDLETON, S. H., 1991, n. ${ }^{\circ} 225$.

67 ZAZOFF, P., 1965, n. ${ }^{\circ}$ 37; ZWIERLEIN-DiEHL, E., 1991, n. ${ }^{\circ}$ S 1840; 1844-1845;

CASAl Garcia, R., 1991, n. ${ }^{\circ}$ 392; LOPEZ DE LA ORden, D., s. d., n. ${ }^{\circ}$ 158; RiCHTER, G., 1956, n. ${ }^{\circ}$ 516; MaASKant-KleibrinK, M., 1978, n. ${ }^{\circ}$ 1022; Sena ChiesA, G., 1966, n. ${ }^{\circ}$ 1061; Sena ChIESA, G., 1978, n. ${ }^{\circ} 124$; Gramatopol, M., 1974, n. ${ }^{\circ} 510$.

68Encontrado nas Grandes Termas do Sul (na sua ficha de inventário, diz-se ser proveniente da Zona H 2). Deu entrada no Museu de Conimbriga em Junho de 1962.

Conimbriga, 40 (2001) 141-197 


\section{Motivo:}

\section{CENA DE CAÇA}

Javali correndo para a esquerda, perseguido por um cão, representado em primeiro plano. Linha de solo.

\section{Paralelos:}

Aquileia, ZWIERLEIN-DieHL, E. (1991), p. 85, est. 32, n. ${ }^{\circ} 1798$

Egipto, ZWIERLEIN-DieHL, E. (1991), p. 86, est. 32, n. ${ }^{\circ} 1800$

Viena, ZWIERLEIN-DieHL, E. (1991), p. 85, est. 32, n. ${ }^{\circ}$ s 1797 e 1799.

Extremamente abundantes em Itália como, aliás, em quase todas as regiões do Império, desde os finais da República que os javalis eram mantidos em parques privados (vivaria) pertencentes a grandes senhores e imperadores (como Nero). Não seria apenas pelo simples prazer da sua presença e contemplação (próprio do espírito da aurea mediocritas) mas também por razões de ordem prática, já que eles constituiam uma importante fonte de alimento (em ocasiões especiais, como banquetes) e de reserva para espectáculos, sacrifícios religiosos e caça. Para além da sua ligação à História de Roma, segundo a lenda ${ }^{69}$ ou a realidade ${ }^{70}$. Por outro lado, tendo já sido emblema de guerra entre os Celtas, viria também a ser um dos emblemas da XX Legião Valeria Vitrix e, por vezes, da X Legião Fretensis (estacionada na Macedonia desde 30 a. C.)

Desde muito cedo que o javali aparece em moedas e gemas gregas e em escaravelhos etruscos dos Séc. V a. C. ${ }^{71}$ e IV a. C. ${ }^{72}$. Popular viria também a ser na Glíptica romana, quer como motivo isolado ${ }^{73}$ (corpulento e de focinho bem saliente, como pode ver-se numa pasta vítrea encontrada no concelho de Constança ${ }^{74}$ ) quer em cenas de caça (um tema igualmente comum em cunhos monetários $^{75}$ e na $\left.A r e^{76}\right)$. Contudo, em algumas delas, o javali é trespassado pela lança

${ }^{69}$ Segundo a lenda, Eneias, ao desembarcar na costa italiana, viu uma javalina com 30 crias tal como previra o deus-rio Tibre.

${ }^{70}$ Nomeadamente, durante a guerra contra Pirro.

${ }^{71}$ NeVEROV, 1976, n. ${ }^{\circ} 17$.

${ }^{77}$ SPIER, J., 1992, n. ${ }^{\circ} 120$.

73 Krug, A., 1980, n. ${ }^{\circ}$ 411; ZWIERLein-Diehl, E., 1991, n. ${ }^{\circ}$ 1885; CASAL Garcia. R., 1980, n. 2 e CASAl Garcia, R., 1995, p. 210; Casal Garcia, R., 1991, n. ${ }^{\circ}$ S 145 e 413; Middleton, S. H., 1991, n. ${ }^{\circ}$ s 24; 211; Guiraud, H., 1988, n. ${ }^{\circ}$ s 696-697; Marshall, F. H., 1907, n. ${ }^{\circ}$ 479; Sena Chiesa, G., 1966, n. ${ }^{\circ}$ s 1091-1092; Sena Chiesa,G., 1978, n. ${ }^{\circ}$ s 14; 134-135; Henig-Whiting, 1987, n. ${ }^{\circ} 351$.

${ }^{74}$ CAndeias, J. e BAtista, A., (1989), "Romanização da margem esquerda do Zêzere - Abordagem Sumária”. Actas do Seminário: Espaço Rural da Lusitânia Tomar e o seu Território, Tomar, p. 71-78.

${ }^{75}$ Em cunhos monetários de 60 a. C. e de Augusto, de 18 a. C.

Conimbriga, A0 (2001) 141-197 
do caçador ${ }^{77}$. Noutras, é atacado por dois cães ${ }^{78}$ (motivo que já se encontra em gemas gregas $^{79}$ ) ou por um leão ${ }^{80}$ (um tema com antecedentes em escaravelhos etruscos ${ }^{81}$ ). Mais raramente, porém, o cão lança-se mesmo sobre ele 8283 .

\section{Bibliografia:}

França, Elsa Ávila. "Anéis, braceletes e brincos de Conimbriga". Conimbriga, VIII, p. 41, n. ${ }^{\circ}$ 1, est. V, n. ${ }^{\circ} 1$. Coimbra, 1969

alarcão, A. M. e Ponte, S., Colecções do Museu Monográfico de Conimbriga - Catálogo, p. 95, n. ${ }^{\circ}$ 404.1. (fig. na pág. 72, n. ${ }^{\circ}$ 16). Coimbra, 1984 alarcão, Adília Moutinho, Museu Monográfico de Conimbriga - Colecções, p. 131, n. ${ }^{\circ}$ 404.1. Instituto Português de Museus, Lisboa, 1994.

Natureza: pasta vítrea, imitando a ametista; Cor: tom de beringela

Forma: oval, plano-convexa; Faces: superior levemente convexa e base plana

Dimensões: $11 \mathrm{~mm}$ X $15 \mathrm{~mm}$ X $2 \mathrm{~mm}$

Estado de conservação: ligeiramente fragmentado no bordo inferior esquerdo

Número de inventário: A 427

Motivo:

\section{GRIFO}

Grifo, sentado, de perfil à esquerda. Linha de solo. De realçar, que tanto o peito como o rosto, vagamente femininos, se assemelham aos de uma esfinge.

\section{Paralelos:}

Aquileia, Sena Chiesa, G. (1966), p. 372, est. LXI, n. ${ }^{\circ} 1207$

Madrid, CASAL GARCIA, R. (1991), p. 172, n. ${ }^{\circ} 421$.

$76 \mathrm{Na}$ arte provincial (Inglaterra, Cartago, Cós e Trier), em relevos (num mármore de Pompeia e no Arco de Constantino), sarcófagos, mosaicos, estátuas e objectos de vidro (de que são exemplo alguns frascos de perfume patentes no Museu de Colónia).

77 RighetTi, R., 1955, n. ${ }^{\circ} 143$; ZWIERLEIN-DiEHL, E., 1991, n. ${ }^{\circ} 1681$.

78 Furtwàngler, A., 1900, est. XLV, n. ${ }^{\circ}$ 16; ImHoOf-Blumer, F. e Keller, O., 1972, est. XIX, n. ${ }^{\circ}$ 56; HeNIG-Whiting, 1987, n. ${ }^{\circ}$ 371; NeVEROv, O., 1988, n. ${ }^{\circ} 68$.

79 FURTWÀngLER, A., 1900, est. XI, n. ${ }^{\circ} 11$.

80 Sena ChIESA, G., 1966, n. ${ }^{\circ} 1204$; FurTwàngler, A., 1900, est. XLV, n. ${ }^{\circ} 24$.

81 FURTWÀnGLER, A., 1900, est. VII, n. ${ }^{\circ} 68$.

82 MaAsKant-KleibrinK, M., 1978, n. ${ }^{\circ} 756$.

83 Encontrado na "Casa dos Repuxos" (na sua ficha de inventário, diz-se que é proveniente de “A 17”). Deu entrada no Museu de Conimbriga em Junho de 1962. 
Consagrado a Apoio $^{84}$ ou a Dionysos ${ }^{85}$ e representado com bico de águia, corpo de leão e asas poderosas, o grifo foi, tal como a esfinge, um tema preferencial na Arte, nos cunhos monetários e na Glíptica grega e romana ${ }^{86}$. No caso desta última, para além de poder constituir um motivo isolado (sentado $^{87}$, caminhando ${ }^{88}$ ou voando ${ }^{89}$ ), aparece também associado a elementos animais (a salamandra ${ }^{90}$, uma cabeça de carneiro, que pisa ${ }^{91}$ ) e vegetais (um ramo $^{92}$ ) e, até, a objectos (uma lança ${ }^{93}$, a roda de Nemésis — a roda do Destino - em que apoia uma pata $\left.{ }^{94}\right)$.

\section{Bibliografía:}

França, Elsa Ávila. "Anéis, braceletes e brincos de Conimbriga". Conimbriga, VIII, p. 42, n. ${ }^{\circ}$ 2. Coimbra, 1969

84 Cujos tesouros os grifos guardavam dos assaltos dos Arimaspes, na índia (ou, segundo outra versão, no país dos Hiperbóreos ou, segundo outra ainda, no dos Etíopes).

85 Tidos como guardiões da sua cratera, repleta de vinho, em tradições mais recentes, aos grifos era atribuída a função de vigiar as montanhas desérticas do Norte da índia, ricas em minas de ouro e seu local de nidificação.

86 A esfinge, já presente em moedas de Chios, aparece em certos cunhos glípticos com as asas encurvadas para cima - um modelo que deverá inspirar-se directamente em motivos de tradição oriental, bastante difundidos em moedas e gemas gregas dos Séc. V e IV a. C. (Neverov, O., 1976, n. 49; MAASKAnT-KleibrinK, M., 1978, n. ${ }^{\circ}$ 13). Na Glíptica romana, porém, a sua representação apenas viria a generalizar-se a partir do momento em que Augusto a usou como emblema, num selo de Estado. Curiosamente, nalguns casos (ZWIERLEIN-DIEHL, E., 1991, n. ${ }^{\circ} 1752$ e MidDLETON, S. H., 1991, n. ${ }^{\circ}$ s 134-135), tem um caduceu associado, o que poderá simbolizar uma identificação de Augusto a Mercúrio.

87 KRUG, A., 1980, n. ${ }^{\circ}$ 32; ZWIERLEIN-DiEHL, E., 1991, n. ${ }^{\circ}$ s 1755-1757; LOPEZ DE LA Orden, D., s. d., n. ${ }^{\circ}$ 207; Berry, B., 1969, n. ${ }^{\circ}$ 142; Richter, G., 1956, n. ${ }^{\circ} 397$; Sena Chiesa, G., 1966, n. ${ }^{\circ}$ s 1207; 1212-1213; SEnA ChIESA, G., 1978, n. ${ }^{\circ}$ 164; HenIG-WHITING, 1987, n. ${ }^{\circ}$ s 393-394; GRAMATOPOL, M., 1974, n. ${ }^{\circ} 585$.

88 SenA ChIESA, G., 1966, n. ${ }^{\circ} 1205$; Gramatopol, M., 1974, n. ${ }^{\circ} 584$.

89 LOPEZ DE LA ORDEN, D., s. d., n. ${ }^{\circ} 208$; RiCHTER, G., 1956, n. ${ }^{\circ} 398$; SENA

ChiESA, G., 1966, n. ${ }^{\circ}$ s 1208-1209; HeNIG-Whiting, 1987, n. ${ }^{\circ} 395$.

90 Sena ChIESA, G., 1966, n. ${ }^{\circ} 1210$ (motivo também presente em moedas de $L$. Papius, de 78-77 a. C.).

91 MAASKANT-KLEIBRINK, M., 1978, n. ${ }^{\circ} 188$.

92 KRUG, A., 1980, n. ${ }^{\circ} 228$.

93 Sena ChiesA, G., 1966, n. ${ }^{\circ} 1211$.

94 KRUG, A., 1980, n. ${ }^{\circ}$ 227; ZWIERLEIN-DIEHL, E., 1991, n. ${ }^{\circ}$ s 1758-1759; BERRY, B., 1969, n. ${ }^{\circ}$ 141; MAASKANT-KLEIBrinK, M., 1978, n. ${ }^{\circ}$ s 693-694; SenA ChiESA, G., 1966, n. ${ }^{\circ}$ 1206; HENIG-WHITING, 1987, n. 396.

Conimbriga, 40 (2001) 141-197 
Alarcão, A. M. e Ponte, S., Colecções do Museu Monográfico de Conimbriga - Catálogo, p. 95,n. ${ }^{\circ}$ 404.8. (fig. na pág. 72, n. ${ }^{\circ}$ 18). Coimbra, 1984 AlarCão, Adília Moutinho, Museu Monográfico de Conimbriga - Colecções, p. 131, n. ${ }^{\circ}$ 404.8. Instituto Português de Museus, Lisboa, 1994.

Natureza: cornalina; Cor: avermelhada; Forma: circular

Faces: planas, com os bordos cortados para dentro; Dimensões: 13,5

$\mathrm{mm}$ X 2,2 mm

Estado de conservação: partida em dois pedaços, quando encontrada, e agora colada

Número de inventário: A 422

Motivo:

\section{COMBINAÇÃO}

Cabeça de Sileno, de perfil à esquerda, conjugada com o corpo de um golfinho (formando a sua testa e cráneo) e um bico de águia. Por baixo, duas cápsulas de papoila e, atrás, um feixe. Trata-se de um gryllos ou combinação de vários elementos que, originando uma figura grotesca, teria um carácter apotropaico.

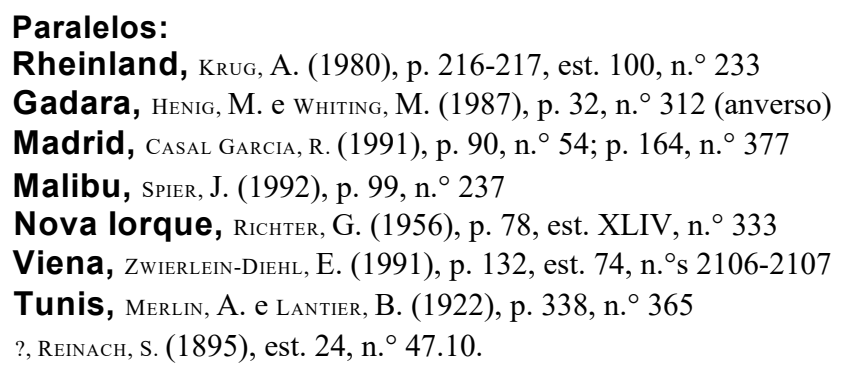

A origem dos grylloi ou "combinações" deve buscar-se na época fenícia e em anéis e peças glípticas do Séc. V a. C., como se deduz de gemas greco-fenícias e anéis aqueménidas encontrados em Ur. Introduzidos em Roma via Grécia helenística, viriam a ser especialmente populares entre os finais do Século I a. C. e meados do Século I d. C. Na maior parte dos casos, essas com- 95

95 Encontrado sob os mosaicos do peristilo central da "Casa dos Repuxos" (na sua ficha de inventário, especifica-se que é procedente de "A 17, Sondagem 3, 4a camada, Ia escolha”). Deu entrada no Museu de Conimbriga em Junho de 1962.

Conimbriga, 40 (2001) 141-197 
binações grotescas e monstruosas teriam um carácter simbólico, muito próximo do dos amuletos egípcios, já que lhes eram atribuídas, como funções, proteger contra o mau olhado e garantir fertilidade, prosperidade, paz, felicidade e boa sorte ao seu portador.

Dos diferentes tipos de combinações (de aves ou de outros animais, de máscaras humanas ou de seres mitológicos), as mais comuns eram as que tinham a máscara de Sileno $^{96}$ conjugada com a de outras divindades (Atena-Minerva ${ }^{97}$, Sátiro ${ }^{98}, \operatorname{Pan}^{99}$ ou Ménade ${ }^{100}$ — as duas primeiras representadas, no nosso território, por exemplares inéditos encontrados no Alentejo e um outro existente no Museu Quinta das Cruzes, no Funchal).

Mas, é também frequente a máscara de Sileno conjugar-se com elementos animais — um caranguejo ${ }^{101}$; uma cabeça de carneiro ${ }^{102}$; um prótumo de cavalo (hippalektryon) e ainda, uma cabeça de Pan (uma associação de bom

96 Por vezes, aparecem apenas duas cabeças de Sileno geminadas (MAASKANT-KleibrinK, M., 1978, n. ${ }^{\circ}$ 768; Sena Chies A, G., 1966, n. ${ }^{\circ}$ s 1001-1002; Gramatopol, M., 1974, n. ${ }^{\circ}$ 614) ou até cinco, formando um cacho de uvas (RICHTER, G., 1956, n. $\left.{ }^{\circ} 553\right)$.

97 A conjugação de uma ou várias cabeças de Sileno com o busto de Atena-Minerva constitui um motivo bastante curioso e cheio de simbolismo. Na opinião de Raquel Casal Garcia (1991, p. 163), simbolizaria a conjugação da máxima Sabedoria, uma vez que Sileno (cujo rosto já Platão e Xenofonte diziam assemelhar-se ao de Sócrates), embora de aspecto disforme e permanentemente ébrio, era extremamente sábio e Atena-Minerva era a deusa da Razão e da Ciência. Os exemplos dessa associação são numerosos: KRUG, A., 1980, n. ${ }^{\circ}$ s 35; 234; 361; LIPPOLD, G., 1922, est. CXVII, n. ${ }^{\circ}$ 1; Casal Garcia, R., 1991, n. ${ }^{\circ}$ s 23 e 373-375; Casal Garcia, R. e Chaves Tristan, F., 1995, n. ${ }^{\circ}$ 28; Alfaro, C., 1996, n. ${ }^{\circ} 24$; Middleton, S. H., 1991, n. ${ }^{\circ}$ s 38; 255-256; Guiraud, H., 1976, n. ${ }^{\circ} 12$ e Guiraud, H., 1988, n. ${ }^{\circ}$ 896; Guiraud, H., 1988, n. ${ }^{\circ}$ 895; Gesztelyi, T., 1987, n. ${ }^{\circ}$ 66; Marshall, F. H., 1907, n. ${ }^{\circ}$ s 421-422; CASAL GARCIA, R. e CRA VINHO, G. (no prelo).

98 Zwierlein-Diehl, E., 1991, n. ${ }^{\circ}$ 2091; CASAl Garcia, R., 1991, n. ${ }^{\circ}$ s 378-379 (?); Casal Garcia, R. e Chaves Tristan, F., 1995, n. ${ }^{\circ} 32$; Spier, J., 1992, n. ${ }^{\circ} 206$; Middleton, S. H., 1991, n. ${ }^{\circ}$ 107; Guiraud, H., 1988, n. ${ }^{\circ}$ 897; GeszTelyi, T., 1987, n. ${ }^{\circ}$ 67; Richter, G., 1971, n. ${ }^{\circ}$ 192; Sena Chiesa,G., 1966, n. ${ }^{\circ}$ 1000; Gramatopol, M., 1974, n. ${ }^{\circ}$ s 76; 615; MAASKANT-KLEIBrinK, M., 1978, n. ${ }^{\circ}$ 647; CrA VINHO, G., 2000, est. I, n. ${ }^{\circ} 8$; FURTWÀNGLER, A., 1900, est. LXII, n. ${ }^{\circ} 12$; HENIG, M., 1974, n. ${ }^{\circ} 375$.

99 CASAl Garcia, R., 1991, n. ${ }^{\circ} 380$; ZWIERLEIN-DiEHL, E., 1991, n. ${ }^{\circ} 2098$;

Guiraud, H., 1988, n. ${ }^{\circ} 898$; GramatOPOL, M., 1974, n. ${ }^{\circ}$ s 608-609.

100 ZWIERLEIN-DieHL, E., 1991, n. ${ }^{\circ}$ 2090; MAASKANT-KLEIBRINK, M., 1978, n. ${ }^{\circ} 106 ;$ MARSHALL, F. H., 1907, n. ${ }^{\circ} 1180$.

101 RiCHTER, G., 1956, n. ${ }^{\circ} 551$.

102 ZWIERLEIN-DieHL, E., 1991, n. ${ }^{\circ} 2119$; CASAL GARCIA, R., 1991, n. ${ }^{\circ} 383$;

RICHTER, G., 1956, n. ${ }^{\circ} 552$.

Conimbriga, 40 (2001) 141-197 
augúrio 103) e/ou um prótumo de elefante (segurando na tromba um tridente ${ }^{10} \mathrm{~A}$ uma tocha acesa ${ }^{103} 104105$ ou uma palma ${ }^{106}$ ); uma ${ }^{107}$ ou mais cabeças de javali e dois prótumos de cavalo ${ }^{108}$ (em gemas que deveriam funcionar como amuletos para a caça).

Mais raramente, porém, a cabeça de Sileno (com a nuca em forma de bico de águia) assenta em patas de avestruz e é encimada por um rato que, fazendo de auriga, segura a avestruz pelas rédeas ${ }^{109 *}$.

\section{Bibliografía:}

França, Elsa Ávila. "Anéis, braceletes e brincos de Conimbriga". Conimbriga, VIII, p. 43, n. ${ }^{\circ}$, est. V, n. ${ }^{\circ} 7$ (interpretado como "um velho barbado"). Coimbra, 1969

alarcão, A. M. e Ponte, S., Colecções do Museu Monográfico de Conimbriga - Catálogo, p. 95, n. 404.5 (interpretado como "cabeça de velho calvo e barbado"). Coimbra, 1984

alarcão, Adília Moutinho. Museu Monográfico de Conimbriga Colecções, p. 131, n. ${ }^{\circ}$ 404.5. (interpretado como "cabeça de velho calvo e barbado"). Instituto Português de Museus, Lisboa, 1994.

\section{B - Período Imperial}

9110

Séc.Id. C.

Natureza: cornalina; Cor: alaranjada; Forma: oval, plano-convexa

Faces: superior convexa e base plana, com os bordos cortados para dentro

103CASAl Garcia, R., 1991, n. ${ }^{\circ}$ 381; KochaV, S., 1995, p. 76.

104 RICHTER, G., 1956, n. ${ }^{\circ} 555$.

ios RichteR, G., 1956, n. ${ }^{\circ}$ 554; MAASKANT-KLEIBRINK, M., 1978, n. ${ }^{\circ} 1095$.

$\mathrm{i}^{\circ 6}$ ZWIERLEIN-Diehl, E., 1991, n. ${ }^{\circ} 2103$; CASAl GARCIA, R. e CR A VINHO, G.

(no prelo).

107 ZWIERLEIN-DiEHL, E., 1991, n. ${ }^{\circ} 2104$; CASAL GARCIA, R., 1991, n. ${ }^{\circ} 382$;

BOARDMAN, J., 1968, n. ${ }^{\circ} 97$.

$\mathrm{i}^{\circ 8}$ Um motivo estranho, gravado numa gema de Ibiza (Vide: AstrUC, M., 1954, n. $\left.{ }^{\circ} 70\right)$.

$10^{9}$ Sena Chies A, G., 1966, n. ${ }^{\circ} 1007$; ZWIERLEIN-DieHL, E., 1991, n. ${ }^{\circ}$ s $2117-$

-2118; CASAl GARCIA, R. e CRA VINHO, G. (no prelo).

no Proveniente de escavações antigas, antes da criação do Museu de Conimbriga (onde deu entrada em Junho de 1962), fez parte do acervo do Museu Nacional Machado de Castro, em cujo inventário tinha o número 185.

Conimbriga, 40 (2001) 141-197 
Dimensões: $17 \mathrm{~mm}$ X $11 \mathrm{~mm}$ X 4,5 mm; Estado de conservação: bom Número de inventário: A 424 Motivo:

\section{MARS ULTOR}

Marte estante, com a perna direita recuada, o corpo ligeiramente a três quartos e a cabeça voltada à direita. Despido, apenas com um manto pelas costas e ostentando elmo, apoia no ombro direito o escudo e segura, na mão esquerda, a lança, pelo topo. Linha de solo.

\section{Paralelos:}

Luni, Sena ChIESA, G. (1978), p. 50, est.. I, n. ${ }^{\circ} 2$

Aquileia, Sena Chiesa, G. (1966), p. 313, est. XLV,n. ${ }^{\circ} 883$; p. 316, est. $\mathrm{XLV}, \mathrm{n} .{ }^{\circ} 895$

Rheinland, Krug, A. (1980), p. 206, est. 91, n. ${ }^{\circ} 169$

Nápoles, Breglia, L. (1941), p. 70, n. ${ }^{\circ} 544$

Cambridge, HeniG, M. (1975), p. 19, n. ${ }^{\circ} 32$.

Divindade itálica muito antiga, ligada ao mundo agrário (donde, a designação de Mars Gradivus), Marte foi identificado a Ares, o deus grego da guerra. Do seu culto no actual território português, há testemunhos epigráficos em Caminha, Conimbriga, Tomar, Egitânia, Miróbriga e na villa de Torre de Palma - neste último caso, um testemunho simultáneamente epigráfico e iconográgfico, pois se trata de um altar com a representação de Mars Ultor, em posição frontal ${ }^{111}$. Curiosamente, tanto em Miróbriga como em Torre de Palma, Marte deveria ter tido, não o papel de divindade guerreira, mas agrária.

Como seria natural, numa Civilização como a Romana, que se foi formando e desenvolvendo com a própria expansão territorial, foi uma divindade profusamente representada, quer na Arte quer em cunhos monetários e glípticos. E nestes últimos, sob diversos tipos e muito mais frequentemente do que Ares o havia sido entre os Gregos.

O mais popular de todos, sobretudo na área mediterrânica do Império, foi, exactamente, o de Mars Ultor — um tema já presente em gemas etruscas. Provavelmente copiado de uma estátua que, no Século II d. C., fora colocada no templo que lhe era dedicado, no forum de Augusto, teria sido inspirado num modelo helenístico despido. Daí que, com ele, seja costume identificar os guerreiros que apenas usam uma clâmide (sobre os ombros ou pendendo do braço), seguram um escudo (ao ombro ou pousado no solo) e empunham uma lança (por vezes, sobreposta por uma águia). Mais raramente, Marte aparece

${ }^{111}$ ALARCÃo, J., 1987, p. 171-172, foto n. ${ }^{\circ} 67$. 
em posição policletiana, com um escudo aos pés, e segura, numa mão, um troféu e, na outra, a lança e o escudo'17 ou está junto a uma coluna, em que o apoia112 113 . Ou, no caso de gemas gnósticas, acorrentando Vénus ${ }^{114}$ — de que há um exemplo, no nosso país, num belo jaspe, de origem desconhecida, na posse de um particular ${ }^{115}$.

No esquema mais comum, porém, tanto em lucernas e estátuas de bronze como em moedas e gemas, vêmo-lo com couraça, botas e grevas ${ }^{11} 117$ 118^. Estante, em posição frontal, com a cabeça de perfil ostentando elmo e mantendo, pelos ombros, a clâmide e, como armas, o escudo e a lança ou a espada (de que é exemplo como num entalhe inédito, encontrado em Braga), a sua identificação é, por vezes, facilitada pela existência de uma inscrição no próprio campo da gema ou das moedas. Está, no primeiro caso, um exemplar em que figura a legenda MARS ULTOR $117 \mathrm{e}$, no segundo, cunhos monetários de Antonino Pio com a de MARTI ULTORI/S.C. ${ }^{118}$

\section{Bibliografía.}

Cardozo, Mário. "Pedras de anéis Romanos encontradas em Portugal".

Revista de Guimarães, LXXII, n. ${ }^{\circ} \mathrm{s} 1$ e 2, p. 155-160, n ${ }^{\circ} 1$. Guimarães, 1962 França, Elsa Ávila. "Anéis, braceletes e brincos de Conimbriga". Co-

nimbriga, VIII, p. 42, n. ${ }^{\circ}$ 3, est. V, n. ${ }^{\circ}$ 3. Coimbra, 1969 alarcão, A. M. e ponte, S., Colecções do Museu Monográfico de Conimbriga - Catálogo, p. 95, n. ${ }^{\circ}$ 404.6. Coimbra, 1984

alarcão, Adília Moutinho. Museu Monográfico de Conimbriga - Colecções, p. 131, n. ${ }^{\circ}$ 404.6. Instituto Português de Museus, Lisboa, 1994.

112 MaIOLI, M. G., 1971, n. ${ }^{\circ} 25$.

ns TAMMA, G., 1991, n. ${ }^{\circ} 33$.

114 Delatte, A. - Derchain, P., 1964, n. ${ }^{\circ}$ s 330-332.

$11^{5}$ CRAVINHO, G., 2000, est. II, n. ${ }^{\circ} 9$.

116 Guiraud, H., 1988, n. ${ }^{\circ}$ s 103; 105-124; SENA ChIESA, G., 1966, n. ${ }^{\circ}$ s 209-216;

KrUG, A., 1980, n. ${ }^{\circ}$ s 23; 106; 248 e 249; KrUG, A., 1978, n. ${ }^{\circ}$ s 11 e 28; MidDLETON, S. H., 1991, n. ${ }^{\circ} 62$ e Ap. I, n. ${ }^{\circ}$ 7; Condurachi, E., 1970, n. ${ }^{\circ}$ 282; HeniG - Whiting, 1987, n. ${ }^{\circ}$ s 220-222; CASAL GARCIA, R., 1991, n. ${ }^{\circ}$ s 225-230; RICHTER, G., 1971, n. ${ }^{\circ}$ 122; TAMMA, G., 1971, n. ${ }^{\circ}$ 36; RUSEVA-SlOKOSKA, L., 1991, n. ${ }^{\circ}$ 250; ZWIERLEIN-DieHL, E., 1991, n. ${ }^{\circ}$ S 2540-3; 2540-30; 2766; TRUMMER, R., 1981/82, n. ${ }^{\circ}$ s 10 e 14; MAASKANT-KLEIBRINK, M., 1978, n. ${ }^{\circ}$ S 452; 738-739; 971; 984-985; Gramatopol, M., 1974, n. ${ }^{\circ}$ S 193-195; 197-198; Middleton, J. H., 1969, n. ${ }^{\circ}$ 48; Henig, M., 1975, n. ${ }^{\circ} 31$; TAYLOR, G., 1978, n. ${ }^{\circ} 170$.

117 FuRTWÀngLeR, A., 1900, est. LXV, n. ${ }^{\circ} 35$.

118 Citações de RiCHTER, G. (1956, p. 72, a propósito do n..$^{\circ}$ 294) e de MAIOLI,

M. G. (1971, p. 32, a propósito do n. $\left.{ }^{\circ} 27\right)$.

Conimbriga, 40 (2001) 141-197 
Séc.IId.C. leitoso

Natureza: ágata de capas (?); Cor: laranja-acastanhado sobre branco

Forma: oval (engastado num anel moderno)

Mesa: plana, com os bordos cortados para fora; Dimensões: $14 \mathrm{~mm} \mathrm{X}$ $11 \mathrm{~mm}$

Estado de conservação: bom; Paradeiro actual: colecção particular ${ }^{120}$ Motivo:

\section{ATHENA NIKEPHOROS}

Atena-Minerva estante, em posição frontal e a cabeça de perfil à esquerda, ostentando um elmo corintio, do qual pendem fitas esvoaçando. $\mathrm{Na}$ mão direita, estendida, tem pousada uma estatueta de Vitória, que lhe oferece uma coroa de louros. Na mão esquerda, segura o escudo e a lança, em posição ligeiramente oblíqua. Linha de solo.

\section{Paralelos:} cida?) $)^{121}$

Mérida, SÁEnz DE BuruagA, J. A. (1946), p. 5, est. I, n. ${ }^{\circ} 8$ (desaparen. ${ }^{\circ} 66$

Sevilha, CASAl GARCiA e Chaves TRISTAN, F. (1995), p. 330, fig 4

Laon, Guiraud, H. (1988), p. 95, est. VI, n. ${ }^{\circ} 74$

Aqui leia. Sena Chiesa, G. (1966), p. 123-124, est. VI, n. ${ }^{\circ}$ s 107-110

Colónia, Krug, A. (1980), p. 189, est. 78,n. ${ }^{\circ} 83$; p. 221, est. 105,n. ${ }^{\circ} 264$

Münster, Stupperich, R. (1988), p. 295-296, n. ${ }^{\circ} 6$, est. 24 , n. ${ }^{\circ} 9$

Dortmund, Herfort-Косн (1988), p. 271, n. ${ }^{\circ} 31$, est. 23, n. ${ }^{\circ} 7$

Caerleon, Henig, M. (1974), p. 36, n. ${ }^{\circ} 237$

Gadara. Henig, M. e Whiting, M. (1987), p. 19, n. ${ }^{\circ}$ s 153 e 155

Tunísia (sic), SPIER, J. (1992), p. 127, n. ${ }^{\circ} 341$

Madrid, Casal Garcia, R. (1991), p. 122, n. ${ }^{\circ} 195$

Bucareste, Gramatopol, M. (1974), p. 49, est. VII, n. ${ }^{\circ}$ s 132 e 137

Haia, MaAskant-Kleibrink, M. (1978), p. 312, n. ${ }^{\circ} 920$; p. 334 n. ${ }^{\circ} 1019$

119 Segundo o testemunho de uma habitante de Condeixa-a-Velha, a quem o Prof. Bairrão Oleiro o adquiriu, teria sido encontrado em parte incerta das ruínas de Conimbriga.

120 Na posse da família do Prof. Bairrão Oleiro, em cujo ex-libris figurava o motivo nele gravado.

121 Em publicação posterior (LUZON, 1982), não é referida entre os entalhes do Museu de Mérida.

Conimbriga, 40 (2001) 141-197 
Debrecen, Gesztelyi, T. (1987), p. 98, n. ${ }^{\circ} 7$

Nova lorque, Richter, G. (1956), p. 67, est. XXXIX, n. ${ }^{\circ} 269$; Richter, G. (1971), p. 33, n. ${ }^{\circ} 93$

?, RICH, A. (1861), p. 35

?, Reinach, S. (1895), est. 60, n. $^{\circ} 53.2$.

Atena (ou Palas-Atena), brotada, já adulta e armada, da cabeça de Zeus, era feroz, implacável e destemida na guerra. Representada com capacete, lança, couraça (a égide) e escudo (o broquel, no qual fixara a cabeça da Gorgona dada por Perseu) era também a personificação da Sabedoria, da Razão e da Pureza. Identificada, pelos Romanos, a Minerva (uma das divindades mais antigas do panteón latino e um dos elementos da Tríade Capitolina), tem o seu culto atestado, em Portugal, numa ara do Valado (Alcobaça) dedicada à memória de Carísia Quintila.

$\mathrm{Na}$ base das suas representações glípticas, estão obras escultóricas gregas. Assim aconteceu com o tipo de Athena Nikephoros, originado na Athena Parthenos, de Fídias, e já presente em cunhos monetários gregos. Apenas muito excepcionalmente, ela é representada com a cabeça em posição frontal, correspondendo ao modelo fidíaco ${ }^{122}$. O que predomina, de facto, é a postura patente neste entalhe de Conimbriga que, difundindo-se extraordinariamente na época de Augusto, perdurou ao longo de todo o Império.

Nalguns casos, porém, empunha verticalmente a lança ${ }^{123}$. E noutros, o escudo está pousado no solo (atrás de si ou na sua frente) ${ }^{124}$ ou numa pequena coluna, em que apoia um braço ${ }^{125}$. Noutros, ainda, segura, na mão estendida, a estatueta de Vitória e a lança e, na outra, apenas o escudo ${ }^{126}$.

Contudo, nem sempre os atributos são os mesmos. O escudo pode estar ausente $^{127}$ ou a lança' ${ }^{128}$ e, em vez dela, a deusa pode empunhar uma es-

122 FURTWÀnGLER, A., 1900, est. XLIV, n. ${ }^{\circ} 66$.

i22 ZWIERLein-Diehl, E., 1991, n. ${ }^{\circ}$ S 2798-2799; SÁENZ DE Buruaga, J. A., 1946, n. ${ }^{\circ}$ 8; SPIER, J., 1992, n. ${ }^{\circ}$ 34; RiChTER, G., 1971, n. ${ }^{\circ}$ 96; MAASKANT-KLEIBRINK, M., 1978, n. ${ }^{\circ}$ 974; SENA ChIESA, G., 1966, n. ${ }^{\circ}$ s 106; 111-112; 116; 118; HenIG-WHITING, 1987, n. ${ }^{\circ}$ S 156-157.

124 Casal Garcia, R., 1991, n. ${ }^{\circ}$ 196; SpIer, J., 1992, n. ${ }^{\circ}$ 274; Guiraud, H., 1988, n. ${ }^{\circ}$ 75; MaAskant-KleibrinK, M., 1978, n. ${ }^{\circ}$ s 708; 973; Sena Chiesa, G., 1966, n. ${ }^{\circ}$ 122; Sena Chiesa, G., 1978, n. ${ }^{\circ}$ 50; Henig-Whiting, 1987, n. ${ }^{\circ}$ 154; Gramatopol, M., 1974, n. ${ }^{\circ}$ S 132-134; HAMBURGER, A., 1968, n. ${ }^{\circ} 36$.

125 Sena Chiesa, G., 1966, n. ${ }^{\circ} 125$; Sena Chiesa, G., 1978, n. ${ }^{\circ} 52$.

126ZWIERLEIN-DIEHL, E., 1991, n. ${ }^{\circ} 2210$.

127ZWIERLEIN-DiEHL, E., 1991, n. ${ }^{\circ} 2800$; SENA ChIESA, G., 1966, n. ${ }^{\circ} 114$.

128HAMBURGER, A., 1968, n. ${ }^{\circ} 35$.

Conimbriga, 40 (2001) 141-197 
pada $^{129}$. Ou ter ao ombro um troféu e empunhar duas espadas ${ }^{130}$. Ou apoiar o cotovelo num escudo, pousado num altar, atrás de $\mathrm{si}^{131}$. Mas, num curioso exemplar, com a lança atrás de si e o escudo aos pés segura, na mão estendida, uma figura de Vitória e na outra, pela cauda, um golfinho ${ }^{132}$.

Muito frequentemente, tem um thymiaterion aos pés ${ }^{133} \mathrm{e}$, por vezes, ainda um escudo, pousado no solo ${ }^{134}$. E, embora raramente, pode também ver-se uma serpente ondulando entre a lança e o elmo (como num entalhe inédito, encontrado no Alentejo) ou entre a lança e o escudo e o thymiaterion ser sobreposto por uma coruja (o animal que lhe estava associado, símbolo da Sabedoria) $)^{135}$.

\title{
Bibliografía:
}

Cardozo, Mário. "Pedras de anéis romanos encontradas em Portugal". Revista de Guimarães, LXXII, n. ${ }^{\circ} \mathrm{s} 1$ e 2,p. 155-160, n. ${ }^{\circ}$ 7. Guimarães, 1962

Paço, Afonso do e Lemos, João de. "Dr. Bairrão Oleiro - A propósito do seu Ex-Libris". Boletim da Academia Portuguesa de Ex-Libris, n. ${ }^{\circ} 37$. Braga, 1966.

Natureza: sardo; Cor: castanha; Forma: oval (engastado num anel em prata, com aro de secção em $\mathrm{D}^{137}$ )

Mesa: plana, com os bordos cortados para fora; Dimensões: $17 \mathrm{~mm} \mathrm{X}$ $13,5 \mathrm{~mm}$

Estado de conservação: bom; Número de inventário: 71.145 Motivo:

\author{
HERMES-MERCÚRIO
}

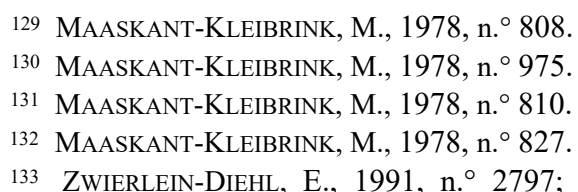

133 ZWIERLEIN-Diehl, E., 1991, n. ${ }^{\circ}$ 2797; MAASKANT-KLEIBRINK, M., 1978, n. ${ }^{\circ}$ 922; Middleton, S. H., 1991, Ap. 4; Sena Chiesa, G., 1966, n. ${ }^{\circ}$ 12; HeniG-Whiting, 1987, n. ${ }^{\circ}$ 152; Gramatopol, M., 1974, n. ${ }^{\circ} 131$.

134 RiCHTER, G., 1971, n. ${ }^{\circ}$ s 97 e 98.

135 RiCHTER, G., 1971, n. ${ }^{\circ} 94$.

136 Tendo em conta as dimensões e talhe da pedra e o tipo de anel em que está engastada.

137 Encontrado em 1971, durante as escavações luso-francesas, perto do praefurnium do laconicum das Termas de Trajano.

Conimbriga, 40 (2001) 141-197 
Mercúrio estante, em posição frontal, com a cabeça de perfil à direita, segurando na mão esquerda a bolsa (marsupio) e na direita o caduceu. Pendendo do braço direito, o manto. Nos pés, calçado alado e na cabeça o pétaso. Linha de solo.
Paralelos:
Borba? Estremoz? - inédita, colecção particular
Italica, Lopez de LA ORden, M. D. (s. d.), p. 122, est. VI, n. ${ }^{\circ} 53$
Vienne, Guiraud, H. (1988), p. 105, est. XII, n. ${ }^{\circ} 171$
Annecy, Guiraud, H. (1988), p. 105, est. XII, n. ${ }^{\circ} 176$
Luni, Sena Chiesa, G. (1978), p. 84, est. X, n. ${ }^{\circ} 65$
Aquileia, Sena Chiesa, G. (1966), p. 138, est. IX, n. ${ }^{\circ} 166$
Sussex, Marshall, F. H. (1907), p. 93, n. ${ }^{\circ}$ 550, est. XVI; Henig, M.

(1974), p. 14, n. ${ }^{\circ} 46$

Ruxox, Henig, M. (1974), p. 13, n. 39

Portchester, Henig, M. (1974), p. 112, Ap. 32

Colonia, Krug, A. (1980), p. 220, est. 104, n. ${ }^{\circ} 257$

Frankfurt, KRUG, A. (1975), p. 125, n. ${ }^{\circ} 25$, est. 34 , n. ${ }^{\circ} 25$

Münster, Stupperich, R. (1988), p. 296-297, n. ${ }^{\circ}$ 9, est. 24 , n. ${ }^{\circ} 11$

Spalato, Middleton, S. H. (1991), p. 57-58, n. ${ }^{\circ} 58$

Trácia do Sul, Ruseva-Slokoska, L., (1991), p. 191, n. ${ }^{\circ} 245$

Alexandria, Mandel-Elzinga, U. (1985), p. 256, est.2, n. ${ }^{\circ} 12 \mathrm{a}-\mathrm{b}$

Cesareia, hamburger, A. (1968), p. 26-27, est. II, n. ${ }^{\circ}$ s 22-24 e 27

Gadara, Henig, M. e Whiting, M. (1987), p. 13, n. ${ }^{\circ} 80$

Baalbeck, Marshall, F. H. (1907), p. 96, n. ${ }^{\circ}$ 566, est. XVI, n. ${ }^{\circ} 566$

Tartüs, marshall, F. H. (1907), p. 97, n. ${ }^{\circ} 567$

Anatolia (sic), НеRFовт-Косн (1988), p. 270, n. ${ }^{\circ} 29$, est. 23, n. ${ }^{\circ} 5$

Ravena, Maioli, M. G. (1971), p. 26-27, n. ${ }^{\circ} 22$

Madrid, Casal Garcia, R. (1991), p. 126, n. ${ }^{\circ} 213$

Bucareste, Gramatopol, M. (1974), p. 56-57, est. Xl-XII, n. ${ }^{\circ}$ s 225; 230

e 237

Londres, Marshall, F. H. (1907), p. 87, n. ${ }^{\circ} 506$

Haia, MaAsKant-KLeibrinK, M. (1978), p. 333-334, n. ${ }^{\circ} 1017$; p. 336-

$-337, \mathrm{n}^{\circ} 1032$

Viena, ZwierLein-Dieht, E. (1991), p. 307, est. 224, n. ${ }^{\circ} 2774$

Vindonissa, Gonzenbach, V. (1952), p. 69. n. ${ }^{\circ} 12$

Debrecen, Gesztelyi, T. (1987), p. 112-113, n. ${ }^{\circ}$ s 22 e 23

Malibu, SPIER, J. (1992), p. 104, n. ${ }^{\circ} 256$

Tunis, hautecoeur, M. L. (1910), p. 343-344, n. ${ }^{\circ}$ s 84-85

Tunis, Merlin, A. e Lantier, B. (1922), p. 335, n. ${ }^{\circ}$ s 334-335.

Mensageiro de Zeus-Júpiter, de movimentos rápidos e graciosos, que o faziam voar à velocidade do pensamento, Hermes-Mercúrio era represen- 
tado com asas nas sandálias, no chapéu de abas largas (o pétaso) e no bastão (o caduceu, símbolo das suas funções de arauto divino). Deus do comércio ${ }^{138}$, protector dos ladrões, comerciantes, pastores ${ }^{139}$, viajantes e dos próprios caminhos ${ }^{140}$, era também o solene guia dos mortos, o condutor das almas para os Infernos (o Hermes Psicopompo).

Inspiradas, muito provavelmente, em modelos escultóricos gregos dos séculos V e IV a. C., as suas representações viriam a ser um dos temas mais difundidos em todas as formas de arte romanas, em especial nas artesanais (baixelas de prata, bronzes, lucernas e sigillata). No caso concreto da Glíptica, aparecem já em exemplares gregos, helenísticos e etruscos. Nestes últimos, sobretudo sob a forma de Hermes Psicopompo, a quem uma pequena figura humana (simbolizando a alma) estende os braços ${ }^{141}$. Muito semelhante, tipo-logicamente, ao de Prometeu modelando uma figura humana, é um motivo que irá perpetuar-se em gemas itálicas de tradição etruscanizante, dos Séculos II I a. C. ${ }^{142}$.

Mas, ao caduceu e em vez da lira, os Romanos acrescentam um novo elemento: a bolsa (marsupio), símbolo dos lucros do comércio. Daí que o tipo mais difundido, sobretudo entre os Séculos I e III d. C., seja exactamente o que vemos em dois exemplares de Conimbriga e noutros, inéditos, encontrados no Alentejo - em posição frontal, cabeça de perfil e segurando bolsa e caduceu. Reproduzindo, talvez, uma estátua de culto existente em Roma, teria sido adoptado, na opinião de Sena Chiesa ${ }^{143}$, como símbolo dos Collegia Mercatorum. Curiosamente, tem uma especial incidência na região mediterrânica (a área comercial por excelência do Império). Tal como na Gália e na Germânia o seu culto teria sido muito popular no actual território português, a julgar até pelo número de inscrições encontradas - três em Lisboa e outras quatro perto de Moura, Braga, S. Pedro do Sul e Fornos de Algodres ${ }^{144}$.

138 A raiz merx significa mesmo mercadoria.

139 Por essa razão, aparece, por vezes, representado com um cordeiro aos ombros - o Hermes Crióforo.

140 Daí que a sua imagem, sob a forma de uma herma itifálica, fosse colocada nas encruzilhadas.

141 Furtwàngler, A., 1900, est. XXI, n. ${ }^{\circ}$ s 64 a 67 e n. ${ }^{\circ} 71$; ZAZOFF, P., 1983, est. 65, 5 e 6; Richter, G., 1956, n. ${ }^{\circ}$ 225; Richter, G., 1971, n. ${ }^{\circ}$ 118; TAMMA, G., 1991, n. ${ }^{\circ}$ 6; SENA CHIESA, G., 1978, n. ${ }^{\circ} 5$.

142 Aliás, a posição encurvada, o manto pendendo dos ombros e os cabelos apanhados junto à nuca são próprios de gemas arcaizantes, cujos temas se inspiram em motivos lendários ou em cultos de mistérios surgidos na Itália Central e, por isso mesmo, alheios ao reportório figurativo grego.

143 SENA CHIESA, G., 1966, p. 137.

144 Aliás, esta última, proveniente de Infias e dedicada por Apónio Sosumo ao deo Mercurio, parece representar a sua identificação a um deus indígena.

Conimbriga, 40 (2001) 141-197 
Em certos casos, há outros elementos associados a este esquema: uma ara aos pés ${ }^{145}$ ou um manto caído pelas costas (como num entalhe inédito, proveniente do Alentejo); os bustos de ísis e de Serápis ${ }^{146}$ ou estrelas (sobretudo em gemas mágicas $)^{147}$. Mas, noutros, é representado sem a bolsa na mão estendida $^{148}$ (um motivo raro, mais fiel ao modelo mais antigo ${ }^{149}$ ) ou nela segurando um ceptro ${ }^{150}$ ou tendo por atributos a palma e a coroa, tal como Vitória ${ }^{151}$.

Outras vezes, o que difere é a própria postura: de perfil (apoiando um pé numa base ou numa pequena elevação de terreno, numa pose semelhante à de Apoio Smintheus, de Scopas, e apenas segurando o caduceu ${ }^{152}$ ou o rhabdos, voltado para baixo ${ }^{153}$ ); visto de costas, ligeiramente a três quartos ${ }^{154}$; olhando para trás ${ }^{155}$; de pernas cruzadas, apoiado numa pequena coluna (numa pose lisipiana semelhante à de Apoio Sauroctonos ${ }^{156}$ ); caminhando ${ }^{157}$; fazendo rolar, pelo chão, um arco (tal como certas representações de Eros) ${ }^{158}$ ou correndo, com o manto a esvoaçar, e apenas segurando o caduceu ${ }^{159}$ ou uma tocha acesa ${ }^{160}$.

145 MAaskant-KLeibrinK, M., 1978, n. ${ }^{\circ} 850$; Gramatopol, M., 1974, n. ${ }^{\circ} \mathrm{s}$ $229 ; 240$.

146 MaAsKant-KleibrinK, M., 1978, $\mathrm{n}^{\circ} 649$.

147 Sena Chies A, G., 1966, n. ${ }^{\circ} 1550$.

148 Gramatopol, M., 1974, n. ${ }^{\circ} 222$.

149 Poderia ser esse o motivo gravado num entalhe inédito proveniente do Alentejo. Infelizmente, ele está mutilado exactamente na região onde a bolsa poderia pender da mão de Mercúrio.

iso CASAl GarCiA, R., 1991, n. ${ }^{\circ}$ 216; MAASKANT-KleibrinK, M., 1978, n. ${ }^{\circ} 701$;

Sena Chiesa, G., 1966, n. ${ }^{\circ}$ 193; Gramatopol, M., 1974, n. ${ }^{\circ} 224$.

151 KRUG, A., 1980, n. $^{\circ} 258$.

152 RiCHTER, G., 1971, n. ${ }^{\circ} 116$; MAASKANT-KLEIBRINK, M., 1978, n. ${ }^{\circ} 363$ b.

153 Sena Chiesa, G., 1966, n. ${ }^{\circ} 205$.

$1^{54}$ MAasKant-KleibrinK, M., 1978, n. ${ }^{\circ} 585$.

155 BERRY, B., 1969, n. ${ }^{\circ} 113$ (a seu lado, um carneiro - um dos animais que, tal

como o galo e a trataruga, lhe estava associado).

156 Righetti, R., 1955, n. ${ }^{\circ}$ s 15-16; Middleton, S. H., 1991, n. ${ }^{\circ}$ 59; SenA ChiesA, G., 1978, n. ${ }^{\circ}$ 25; Henig, M., in "Escavations at Fishbourne, 1961-1969", 1971 (?),p. 87, est. VIII, n. ${ }^{\circ} 1$.

157 ZAZOFF, P., 1965, n. ${ }^{\circ}$ 41; Gramatopol, M., 1974, n. ${ }^{\circ} 223$.

158 MAASKANT-KLEIBRINK, M., 1978, n. ${ }^{\circ} 818$.

$1{ }^{59}$ MaASKANT-KLEIBRINK, M., 1978, n. ${ }^{\circ} 1147$.

160 HeNIG, M., 1975, n. ${ }^{\circ} 38$. 


\section{Bibliografía:}

alarcão, J.; etienne, R.; alarcão, A. e ponte, S., Fouilles de Conimbriga, vol. VII, p. 135 e 138, n. ${ }^{\circ}$ 182, est. XXXII, 182. Paris, 1979

alarcão, A. M. e Ponte, S., Colecções do Museu Monográfico de

Conimbriga - Catálogo, p. 95, n. ${ }^{\circ}$ 403.8. (fig. na pág. 94). Coimbra, 1984

alarcão, Adília Moutinho, Museu Monográfico de Conimbriga - Colecções, p. 130, n. ${ }^{\circ}$ 403.8. Instituto Português de Museus. Lisboa, 1994.

Natureza: nicolo; Cor: cinzento sobreposto por branco ${ }^{163}$; Forma: oval

Faces: planas, com perfil de nicolo; Dimensões: $14 \mathrm{~mm} \mathrm{X} \mathrm{12,2} \mathrm{mm}$ X $3 \mathrm{~mm}$

Estado de conservação: com pequenos sulcos na face gravada, que lhe dão o aspecto de porcelana estalada ${ }^{164}$

Número de inventário: 65.571

Motivo:

\section{HERMES-MERCÚRIO}

Mercúrio, estante, em posição frontal e com a cabeça de perfil para a esquerda. Na mão direita, segura a bolsa (marsupio) e na esquerda o caduceu, que pousa no ombro. Pendente do braço esquerdo, o manto. Na cabeça, ostenta o pétaso e nos pés, calçado alado. Não há linha de solo.

\section{Paralelos:}

Verilanium, Henig, M. (1974), p. 13, n. ${ }^{\circ} 38$

161 Encontrada em 1965, durante as escavações luso-francesas, na camada de destruição da insula do vaso fálico (datável do Séc. V d. C.).

162 No mesmo horizonte, foram encontrados fragmentos de cerâmica e de lucernas do Séc. I d. C. (reaproveitados no adobe?) e um as de 27-25 a. C., com a efígie de Augusto. As outras moedas, porém, vão de meados do Séc. III a finais do IV d. C. (Arcádio) e o restante espólio, proveniente do estrato em que o entalhe apareceu, situa-se entre os Séc. IV-VI d. C. Contudo, pela sua natureza e pela estilização do motivo, deverá enquadrar-se nos Séc. II-III d. C. pelo bordo.

163 A pedra apresenta um veio branco que, partindo da base, se prolonga

164 Um nicolo (?) publicado por Hélène Guiraud (1988, n. ${ }^{\circ}$ 575), datado do Séc. Ia.C. - Id.C., apresenta as mesmas cores e a mesma deterioração (igualmente observável em dois nicolos do Museu de Haia - cf. MAASKANT-KLEIBRINK, M., 1978, n. ${ }^{\circ}$ s621 e 1016, este último datado do Séc. II-III d. C.).

Conimbriga, 40 (2001) 141-197 
Alcester, HeNIG, M. (1974), p. 13-14, n. ${ }^{\circ} 40$

Alexandria, Mandel-Elzinga, U. (1985), p. 255, est. 2, n. ${ }^{\circ} 11$

Cesareia, Hamburger, A. (1968), p. 27, est. II, n. ${ }^{\circ} 26$

Gadara, Henig, M. e Whiting, M. (1987), p. 13, n. ${ }^{\circ} 78$

Haia, MaAskant-Kleibrink, M. (1978), p. 336, n. ${ }^{\circ} 1031$

Bucareste, Gramatopol, M. (1974), p. 56, est. XI, n. ${ }^{\circ}$ s 225 e 230

Cambridge, Middleton, J. H. (1969), pi. II, n. ${ }^{\circ}$ 61, Ap. XVII.

\section{Bibliografía:}

alarcão, J.; etienne, R.; Alarcão, A. e Ponte, S., Fouilles de Conimbriga, vol. VII, p. 135 e 138, n. ${ }^{\circ}$ 192, est. LIX, 5. Paris, 1979

alarcão, A. M. e Ponte, S., Colecções do Museu Monográfico de Conimbriga - Catálogo, p. 95, n. ${ }^{\circ}$ 404.7. (fig. na pág. 72, n. ${ }^{\circ}$ 15). Coimbra, 1984

Alarcão, Adília Moutinho, Museu Monográfico de Conimbriga - Colecções, p. 131, n. ${ }^{\circ}$ 404.7. Instituto Português de Museus, Lisboa, 1994.

Natureza: pasta vítrea imitando o nicolo; Cor: azul-escuro sobreposto por uma camada esbranquiçada

Forma: oval (engastado num fragmento de anel em prata ${ }^{166}$ ); Mesa: plana, com bordo biselado

Dimensões: $8,5 \mathrm{~mm}$ X $6 \mathrm{~mm}$; Estado de conservação: com muita patine

Número de inventário: 70.288

Motivo.

\section{SÁTIRO}

Sátiro, de perfil à esquerda. Com os braços estendidos, talvez segurando uma flauta, ergue a perna direita, como que dançando. Ao ombro, parece ter o tirso com as fitas pendendo. Não é visível linha de solo ${ }^{167}$.

165 Tendo em conta a natureza do entalhe e o tipo de anel (cf. GHIRAUD, H., 1988, est. LXVIII, n. $\left.{ }^{\circ} 644\right)$.

166 Encontrado em 1970, durante as escavações luso-francesas, no nível de ocupação bárbara da zona da insula do vaso fálico - um nível muito superficial e de terras bastante revolvidas, o que explica que os materiais dele provenientes sejam de épocas diversificadas: moedas que vão de Cláudio (um as provincial) a Constâncio II (um bronze de 352-360); cerâmica do Séc. I ao Séc. V; lucernas desde a segunda metade do Séc. I à primeira metade do Séc. II; vidro do Séc. IV.

167 Nas Fouilles de Conimbriga (vol. VII, est. XXXII), o motivo foi desenhado como se a pedra pertencesse ao anel 187.

Conimbriga, 40 (2001) 141-197 


\section{Paralelos:}

Cádis, Lopez de la Orden, D. (s.d.), p. 151, est. XIII, n. ${ }^{\circ} 136$

Sevilha, Casal Garcia, R. e Chaves tristan, F. (1995), p. 320, fig. I, n. ${ }^{\circ} 10$ (frente a uma cratera) $)^{168}$

Haia, Masknant-Kleibrink, M. (1978), p. 315-316, n. ${ }^{\circ} 940$ (com o braço erguido à altura do rosto)

Nova lorque, Richter, G. (1956), p. 78, n. 330 (bebendo de uma taça, com o pé erguido apoiado numa rocha).

Génio da Natureza e elemento do thiasus dionisíaco, o Sátiro era um elemento iconográfico já muito popular na Grécia Arcaica — dançando no campo $^{169}$ ou frente a uma cratera ${ }^{170}$, bebendo com Dionysos ou perseguindo Ménades e ninfas. Tal como Pan, era representado como um ser híbrido (meio homem-meio cavalo ou bode), uma grande cauda e umphalus erecto e de proporções disformes. Lentamente, porém, o seu carácter animalesco foi-se atenuando: embora mantendo a cauda e os pequenos chifres, os cascos foram sendo substituídos por pés.

Quer como elemento do cortejo báquico, quer isoladamente, também na época romana viria a ser um motivo comum em todas as formas artísticas. Particularmente em Glíptica, onde o seu sucesso foi enorme. Inclusive no actual território português, a fazer fé no elevado número de entalhes em que aparece. E nem a repressão do culto dionisíaco, em 186 a. C., nem a sua fiscalização, após ter sido restaurado no Séc. I a. C., parecem ter anulado a produção dos diversos temas, ligados ou ao pensamento religioso ou aos motivos helenísticos então em voga (como os de género bucólico). Retratado como um jovem, sempre despido, normalmente imberbe e com uma aparência quase humana, em certos casos apenas é possível identificá-lo pela curta cauda ou por dois pequenos chifres sobressaindo por entre a farta cabeleira. Como atributos, tem quase sempre o pedum, por vezes a nebride e, mais raramente, o tirso.

Participante activo nas cerimónias dionisíacas, onde a música e a dança conduziam os seus seguidores ao êxtase e à felicidade, era frequentemente representado dançando ao som do tamborim, sozinho ou com as Ménades, em esquemas de dança variados. No caso deste entalhe, parece dançar e tocar flauta. Mas, assumindo uma postura semelhante, pode também, aparecer acompanhado de um cão, saltitando à sua frente171, ou com um cacho de uvas

168 Num catálogo do Museu do Luxemburgo (1989, p. 202, n. $\left.{ }^{\circ} 150\right)$, o Sátiro toca dupla flauta frente ao que parece ser uma herma.

169 LipPOLD, G., 1922, est. XIV, n. ${ }^{\circ}$ (Séc. V a. C.).

170 VollenweIDER, M-L., 1983, n. ${ }^{\circ} 27$ (escaravelho grego).

171 LopezdelaOrden,D., 1989, n. ${ }^{\circ} 14$ e LóPEZ DE LA Orden, D., s. d., n. ${ }^{\circ} 131$. 
na mão estendida ${ }^{172}$ e o pé erguido apoiado numa rocha ${ }^{173}$ ou segurando o tirso e bebendo de uma taça ${ }^{174}$.

\section{Bibliografía:}

Alarcão, J.; Etienne, R.; Alarcão, A. e Ponte, S., Fouilles de Conimbriga, vol. VII, p. 135 e 138, n. ${ }^{\circ}$ 184, est. XXXII, 184. Paris, 1979.

14175 Séc. Ill d. C.

Natureza: pasta vítrea; Cor: negra, com aspecto calcinado; Forma: oval, tronco-cónica

Faces: planas, com bordos cortados para fora; Dimensões: $15 \mathrm{~mm}$ X 12 $\mathrm{mm} \times 3,5 \mathrm{~mm}$

Estado de conservação: superfície gravada um tanto deteriorada e gasta

Número de inventário: não tem

Motivo:

\section{APOLO}

Apolo estante, em posição frontal, cruzando a perna direita sobre a esquerda e com o rosto voltado à esquerda. Despido, apoia o cotovelo direito numa pequena coluna e parece segurar na mão esquerda, abaixada, um ramo de loureiro. Não é perceptível linha de solo.

\section{Paralelos:}

Vienne, Guiraud, H,(1988), p. 89-90, est. III, n. ${ }^{\circ} 34$

Nettleton, HeNIG, M. (1974), p. 11, n. ${ }^{\circ} 24$

Salona, Middeten, S. H. (1991), p. 53, n. ${ }^{\circ} 45$.

Filho de Zeus e de Leto e irmão gémeo de Ártemis, Apoio ficaria célebre pelos seus inúmeros amores, como aquele que, segundo Ovídio, nutriu por Dafne, uma ninfa de espírito independente, que preferiu ser transformada em loureiro ${ }^{176}$ a entregar-se-lhe.

172HeNig, M., 1974, n. ${ }^{\circ} 177$; SeNA ChIESA, G., 1978, n. ${ }^{\circ} 70$.

173 Sena ChIESA, G., 1966, n. ${ }^{\circ} 399$.

174 Henig-Whiting, 1987, n. ${ }^{\circ} 248$.

175 Encontrada em escavações anteriores a 1962, antes da criação do Museu Monográfico de Conimbriga fez parte do acervo do Museu Nacional Machado de Castro.

176 Dafne, em grego - um dos seus atributos (tal como a trípode, a lira, o arco de prata, a aljava e as setas). Era, aliás, com as suas folhas brilhantes que se coroavam os vencedores de torneios e sob o seu efeito que a Pitonisa de Delfos entrava em transe e expressava, em verso, os oráculos.

Conimbriga, 40 (2001) 141-197 
Assimilado pelos Romanos com o mesmo nome, viria a ser uma divindade bastante popular na Arte (onde aparece sempre como um jovem muito belo) e na vida quotodiana de então, como o demonstra o facto de Augusto o considerar seu protector pessoal (atribuindo-lhe mesmo a sua vitória na batalha de Actium, em 31 a. C.) e Horácio uma divindade intermediária entre Júpiter e o povo romano. Em Portugal, o seu culto é atestado por uma estátua encontrada em Alcoutim e por aras provenientes de Lisboa, Mombeja (Beja), Balsa e Conimbriga. Curiosamente, nestas duas últimas, aparece com o epíteto de Augusto - o que poderá ser interpretado como uma forma de culto imperial.

Em Glíptica, a sua faceta de guerreiro e a paixão por Dafne estão bem patentes no esquema mais difundido: estante, em posição frontal e com a cabeça de perfil, despido (ou apenas com um manto pelas costas), segurando, na mão estendida, o ramo de loureiro e com a aljava ao ombro do braço recuado ${ }^{177}$.

Mas, é também frequente a sua representação apoiando-se numa coluna $^{178}$ (por vezes com um braço atrás das costas, numa pose de extrema elegância, de tipo praxitiliano ${ }^{179}$ ) ou cruzando as pernas, como no entalhe acima descrito - um tipo que se combina com o de Apoio Sauroctonos (em que, de pernas cruzadas e com uma seta na mão, se prepara para matar o lagarto que sobe pela árvore à qual se encosta).

Noutros casos, porém, tem na frente uma ara acesa e, atrás da coluna em que se apoia, uma árvore semelhante à de Apoio Sauroctonos ${ }^{180}$. Mas há certas variantes em que se apoia numa trípode ${ }^{181}$ ou segura, na outra mão, o arco (um esquema comum aos cunhos monetários ${ }^{182} \mathrm{e}$, de certo modo, também combinado com o de Apoio Sauroctonos) ${ }^{183}$ e tem ainda aos pés um corvo (um dos animais que lhe estava associado) ${ }^{184}$.

Extremamente rara, porém, é a variante em que, estando junto a uma coluna sobreposta por um vaso, nela não se apoia ${ }^{185}$.

177 Furtwàngler, A., 1900, est. LXIV, n. ${ }^{\circ}$ 59; LOPEZ DE LA ORdEN, D., 1989, n. ${ }^{\circ}$ 1; Lopez De la Orden, D., s. d., n. ${ }^{\circ}$ s 41 e 42; Guiraud, H., 1996, n. ${ }^{\circ}$ 26; Sena CHIESA, G., 1966, n. ${ }^{\circ} 62$; HeNIG-Whiting, 1987, n. ${ }^{\circ}$ s 50-52.

178KRUG, A., 1980, n. ${ }^{\circ} 105$; MAASKANT-KLEIBRINK, M., 1978, n. ${ }^{\circ} 102$; HeNIG-

Whiting, 1987, n. ${ }^{\circ}$ S 47-49; GRAMATOPOL, M., 1974, n. ${ }^{\circ} 144$.

179 FURTWÀnGLER, A., 1900, est. XLII, n. ${ }^{\circ} \mathrm{s} 8$ e 9.

180 Guiraud, H., 1988, n. ${ }^{\circ} 33$.

181 FurTwàngler, A., 1900, est. XLIV, n. ${ }^{\circ}$ 62; SENA ChieSA, G., 1966, n. ${ }^{\circ} 55$.

182 Cf. Sutherland, C. H. V., 1974, n. ${ }^{\circ} 255$.

183 FurTWÀngler, A., 1900, est. XXIV, n. ${ }^{\circ} 44$; MAASKANT-KLEIBRINK, M., 1978, n. ${ }^{\circ} 71$; BoARdMAN, J., 1968, n. ${ }^{\circ}$ 14; MARShall, F. H., 1907, n 1458.

184 Middleton, S. H., 1991, n. ${ }^{\circ} 42$.

185 FURTWÀngler, A., 1900, est. XXXIX, n. ${ }^{\circ} 15$.

Conimbriga, 40 (2001) 141-197 


\section{Bibliografía:}

Cardozo, Mário. "Pedras de anéis romanos encontradas em Portugal". Revista de Guimarães, LXXII, n. ${ }^{\circ} \mathrm{s} 1$ e2,p. 155-160,n. ${ }^{\circ} 2$ (interpretado como "ninfa"). Guimarães, 1962.

$15^{186}$

Séc. Ill d. C.

Natureza: pasta vítrea imitando o nicolo; Cor: negro e cinzento; Forma: oval; Faces: planas, com perfil de nicolo;

Dimensões: $14 \mathrm{~mm}$ X $11 \mathrm{~mm}$ X 2,5 mm

Número de inventário: não tem

Estado de conservação: superfície gravada deteriorada e gasta Motivo:

\section{JUPPITER TONANS (?)}

Figura masculina estante, em posição frontal e a cabeça voltada à direita. Despida, tem o braço esquerdo afastado do corpo e ligeiramente erguido, como se empunhasse, pelo topo, um ceptro, e o direito estendido, como se segurasse uma pátera. Não é perceptível linha de solo.

\section{Paralelos:}

Aquileia, Sena Chiesa, G.(1966), p. 96, est. I, n. ${ }^{\circ} 26$

Luni, Sena Chiesa, G. (1978), p. 76, est. VII, n. ${ }^{\circ} 46$

Little Brickhill, HeNIG, M. (1974), p. 10, n. ${ }^{\circ} 15$.

Principal divindade do panteón romano, senhor do Céu, da luz divina e das condições climatéricas, Júpiter reinava no Capitólio, um monte coberto de carvalhos, a árvore que lhe era especialmente consagrada. Tal como Zeus, a quem foi assimilado, tinha como arma poderosa o raio, que arremessava imprevisivelmente a quem lhe caísse em desgraça (por quebra de juramento ou mentira) e que, brandido violentamente, fazia surgir o trovão e o relâmpago. Porém, à medida que se foram desenvolvendo e fortalecendo as estruturas políticas de Roma, os seus poderes meteorológicos foram-se apagando, face à importância que, progressivamente, lhe era atribuída na vida política. No período imperial, os imperadores colocaram-se mesmo sob a sua protecção. Foi o caso de Augusto, que acreditava que ele o havia milagrosamente salvo da queda de um raio, pelo que mandou erguer, no Capitólio, um templo dedicado a Juppiter Tonans.

186 Talvez a ele se refira Elsa Ávila de França (1969, p. 44), a propósito do n. $^{\circ} 19$.

Conimbriga, 40 (2001) 141-197 
O seu culto mais célebre era o de Juppiter Optimus Maximus de que, em Portugal, há testemunhos nas regiões militarizadas a Norte do Douro e da Egitânia e ainda em zonas rurais, como a do convento bracaraugustano - o que pode representar uma certa assimilação do culto de Júpiter ao de divindades indígenas, na qual os exércitos romanos poderiam ter tido um papel importante.

Relativamente ao tipo de Juppiter Tonans, a sua origem deve buscar-se na arte grega do Séc. IV a. C., provavelmente no Zeus de Argos, de Lisipo. Em Roma, surgiu no período republicano, gravado em cunhos monetários (onde, aliás, viria a manter-se até ao Séc. Ill d. C., em especial na época antonina e na de Cómodo), primeiro sob o epíteto de Tonans e depois de Conservator. Estante, barbado e despido (apenas com um manto pelos ombros, como num entalhe inédito encontrado no Alentejo), segura numa mão o ceptro e na outra o feixe de raios $^{187}$. Frequentemente, como num exemplar inédito proveniente de Ammaia (Aramenha), tem a seus pés a águia retrocéfala, com uma coroa de louros no bico (o animal que lhe estava associado) ${ }^{188}$. Mais raramente, arremessa o raio ${ }^{189}$ ou tem associados símbolos astrais ${ }^{190}$. Ou, em vez do feixe de raios, segura na mão estendida outros atributos: uma pátera ${ }^{191}$; a pátera e, na outra mão, uma cornucopia $^{192}$; a águia retrocéfala ${ }^{193}$; uma coroa $^{194}$; uma palma ${ }^{195}$; uma estatueta de Vitória ${ }^{196} 197$; uma ave, frente a um thymiaterion ${ }^{191}$.

187 MAasKant-KleibrinK, M., 1978, n. ${ }^{\circ}$ S 474 e 769; Alfaro Giner, C., 1996, n. 31 (?); SpIER, J., 1992, n. ${ }^{\circ}$ 421; Guiraud, H., 1976, n. ${ }^{\circ} 2$ e Guiraud, H., 1988, n. ${ }^{\circ}$; Guiraud, H., 1974, n. ${ }^{\circ} 1$ e Guiraud, H., 1988, n. ${ }^{\circ}$ 9; Sena Chiesa, G., 1966, n. ${ }^{\circ} 26$.

188 Lopez de la Orden, D., s. d., n. ${ }^{\circ}$ 39; Casal Garcia, R., 1991, n. ${ }^{\circ}$ s 149-150; Casal Garcia, R. e Chaves Tristan, F., 1995, n. ${ }^{\circ} 24$; Middleton, S. H., 1991, n. ${ }^{\circ} 30$; Sena Chiesa, G., 1966, n. ${ }^{\circ}$ 20; Maioli, M. G., 1971, n..$^{\circ}$ 4; Furtwàngler, A., 1900, est. XLIV, n. ${ }^{\circ} 49 ;$ HeNIG, M., 1974, n. ${ }^{\circ} 14$.

189 MaAskant-KleibrinK, M., 1978, n. ${ }^{\circ} 193$.

190 Sena Chiesa, G., 1966, n. ${ }^{\circ} 29$.

¡9" Alfaro Giner, C., 1996, n. ${ }^{\circ}$ 25; Guiraud, H., 1988, n. 11; Guiraud, H., 1976, n. 3 e GuiRaud, H., 1988, n. ${ }^{\circ}$ 12; MaAskant-KLeibrink, M., 1978, n. ${ }^{\circ} 880$; Henig, M., 1974, n. ${ }^{\circ} 16$; Hamburger, A., 1968, n. ${ }^{\circ} 12$; Sena Chiesa, G., 1966, n. ${ }^{\circ}$ s 21-23; 25; HeNIG-WHITING, 1987, n. ${ }^{\circ}$ s $18-20$.

192 Sena Chiesa, G., 1966, n. ${ }^{\circ} 32$.

193 MaAskant-KleibrinK, M., 1978, n. ${ }^{\circ}$ S 192 e 960; Casal Garcia, R., 1991,

n. ${ }^{\circ}$ 151; GuIRAUd, H.. 1988, n. ${ }^{\circ} 13$.

194 Gramatopol, M., 1974, n. ${ }^{\circ} 102$.

195 Gramatopol, M., 1974, n. ${ }^{\circ} 104$.

196 Sena Chiesa, G., 1966, n. ${ }^{\circ}$ s 27-28; Gramatopol, M., 1974, n. ${ }^{\circ} 103$.

197 HeNIG-WhitING, 1987, n. ${ }^{\circ} 21$. 
Mas, em exemplares mais simplificados, como deverá ser o caso de dois entalhes inéditos, provenientes do Alentejo, para além do ceptro, não detém qualquer outro atributo ${ }^{198}$.

\title{
Bibliografía:
}

Inédito.

$16^{199}$

Séc. II d. C.

\begin{abstract}
Natureza: nicolo;
Cor: azul-leitoso sobre azul muito escuro, quase negro

Forma: oval; Faces: planas, com perfil de nicolo;

Dimensões: $12^{200}$ X $12 \mathrm{~mm}$ X $2 \mathrm{~mm}$

Estado de conservação: incompleto (mutilado na parte superior)

Número de inventário. A 428

Motivo:
\end{abstract}

\section{TESEU (?)}

Figura masculina estante, em posição frontal e despida. O que resta do braço direito está flectido ao nível do cotovelo e, da mão ou do ombro do mesmo lado, deveria pender um manto, parcialmente visível. $\mathrm{Na}$ mão esquerda, erguida, empunha uma espada. Linha de solo. Representação de um guerreiro? De Teseu empunhando a espada oferecida por seu pai? ${ }^{201}$

\section{Paralelos:}

Sevilha, Casal Garcia, R. e Chaves Tristan, F. (1995), p. 327, n. ${ }^{\circ} 47$, fig. 4, n. $^{\circ} 47$

198 MaAskant-Kleibrink, M., 1978, n. ${ }^{\circ} 629$.

199 Encontrado em escavações antigas, fez parte do acervo do Museu Nacional Machado de Castro antes da criação do de Conimbriga, onde deu entrada em Junho de 1962.

200 Dimensão referente à altura do entalhe, tal como está (mutilado na parte superior).

201 A mutilação da pedra não permite uma identificação segura do motivo, já que não são visíveis nem a cabeça nem a mão direita nem o ombro do mesmo lado. Foi interpretado por Mário Cardozo, Elsa Ávila de França e Adília Alarcão como Hércules com a clava e a pele de leão. Contudo, há certas semelhanças com motivos que representam Perseu em posição frontal, com o manto pendendo do ombro e segurando, numa mão, a espada e na outra (cujo braço erguido desenha, sobre a sua cabeça, um arco) a cabeça de Medusa (cf. Sena Chiesa, 1966, n. ${ }^{\circ}$ 726; Henig, M., 1975, n. ${ }^{\circ} 180$ ) - um tema que não é estranho aos mosaicos de Conimbriga. 
Italica, Lopez de LA Orden, D. (s. d), p. 185, est. X, n. ${ }^{\circ} 89$

Colonia, Krug, A. (1980), p. 232, n. ${ }^{\circ} 332$, est. 114 , n. ${ }^{\circ} 332$

Castlesteads, HenIG, M. (1974), p. 63-64, n..$^{\circ} 443$

Haia, MAaSKAnt-KLeibrink, M. (1978), p. 317, n. ${ }^{\circ}$ s 946 e 947

Debrecen, Gesztelyi, T. (1987), p. 145 e 147, n. ${ }^{\circ} 65$.

Teseu (filho de Egeu, rei de Atenas que, antes mesmo de ele nascer, lhe oferecera uma espada que ele teria que desenterrar após remover uma enorme pedra), foi o herói que matou o Minotauro. Tanto um tema como outro são retratados em gemas, talvez destinadas a anéis para soldados que iniciavam a sua carreira militar.

$\mathrm{Na}$ variante mais comum do tipo em que contempla a espada oferecida pelo pai, Teseu aparece de perfil. Umas vezes, tem associada uma coluna, na qual se apoia (numa pose muito próxima da das estátuas de Praxiteles, que se apoiam numa coluna ou num tronco de árvore) $)^{202}$, ou que existe na sua frente ${ }^{203}$. Outras, a coluna está ausente (como pode ver-se num entalhe encontrado em Braga $^{204}$ ), numa pose talvez derivada duma estátua do Séc. IV a. C., da autoria de Silanion ${ }^{205}$. Neste último caso, pode ter o escudo aos pés ${ }^{206}$. $\mathrm{Ou}$ atrás de si e na sua frente o elmo, pousado numa rocha (a que escondia o presente de Egeu? $)^{207}$.

Frequente é, também, a sua representação em posição frontal ${ }^{208}$, como poderia acontecer neste entalhe de Conimbriga.

Noutros exemplares, porém, é a luta com o Minotauro que o artista eterniza ${ }^{209}$. À semelhança, aliás, do que fizeram muitos mosaístas, como o criador dum quadro dum dos mosaicos da villa de Torre de Palma.

202 Middleton, S. H., 1991, n. ${ }^{\circ} 154$.

203 MAASKANT-KLEIBRINK, M., 1978, n. ${ }^{\circ} 712$.

204 Rigaud de Sousa, J. L, 1973, n. ${ }^{\circ} 13$.

205 SPIER, J., 1992, n. ${ }^{\circ}$ 294; GUIRAUD, H., 1988, n. ${ }^{\circ}$ S 455-456; 458-460; Guiraud, H., 1974, n. ${ }^{\circ} 4$ e Guiraud, H., 1988, n. ${ }^{\circ}$ 457; MaASKANT-KleibrinK, M., 1978, n. ${ }^{\circ}$ 944; Gesztelyi, T., 1987, n. ${ }^{\circ}$ 62; TAYlor, G., 1978, n. ${ }^{\circ}$ 132; Sena Chiesa, G., 1966, n. ${ }^{\circ}$ s 720 e 722; GRAMATOPOL, M., 1974, n. ${ }^{\circ} 367$.

206 LOPEZ De La ORden, D., s. d., n. ${ }^{\circ}$ 90; Guiraud, H., 1988, n. ${ }^{\circ}$ s 461-462; MAaskAnT-KleibrinK, M., 1978, n. ${ }^{\circ}$ 713; FurTWÀngleR, A., 1900, est. LXI, n. ${ }^{\circ} 71$ e LIPPOLD, G., 1922, est. XLVIII, n. ${ }^{\circ} 3$; RICHTER, G., 1971, n. ${ }^{\circ}$ s 322 e 324.

207 FurTWÀngler, A., 1900, est. XXXVIII, n. ${ }^{\circ} 18$ e LiPPold, G., 1922, est.

XLIX, n. ${ }^{\circ}$ 6; RICHTER, G., 1971, n. ${ }^{\circ} 323$.

208 KRUG, A., 1980, n. ${ }^{\circ} 332$; LiPPOLD, G., 1922, est. XLII, n. ${ }^{\circ} 2$; ZWIERLEIN-Siehl, E., 1991, n. ${ }^{\circ}$ 1640; Casal Garcia, R. e Chaves Tristan, F., 1995, n. ${ }^{\circ}$ 47; Guiraud, H., 1988, n. ${ }^{\circ} 434$; MAASKANT-KLEIBRINK, M., 1978, n. ${ }^{\circ}$ s 754; 910; 946-947; GesZTElyi, T., 1987, n. ${ }^{\circ} 65$; HeNIG, M., 1974, n. ${ }^{\circ} 443$.

209NeVEROV,0., 1976, n. ${ }^{\circ} 108$.

Conimbriga, 40 (2001) 141-197 
Mas, noutros, foi imortalizada a remoção da enorme pedra que dificultava o desenterramento da sua espada ${ }^{210}$.

\section{Bibliografía:}

Cardozo, Mário. "Pedras de anéis romanos encontradas em Portugal". Revista de Guimarães, LXXII, n. ${ }^{\circ}$ s 1 e 2, p. 155-160, n. ${ }^{\circ} 3$. Guimarães, 1962

França, Elsa Ávila. "Anéis, braceletes e brincos de Conimbriga". Conimbriga, VIII, p. 43, n. ${ }^{\circ}$ 6, est. V, n. ${ }^{\circ}$ 6. Coimbra, 1969

Alarcão, A. M. e Ponte, S., Colecções do Museu Monográfico de Conimbriga - Catálogo, p. 95, n. ${ }^{\circ}$ 404.4. (fig. na pág. 72 , n. ${ }^{\circ}$ 13). Coimbra, 1984

Alarcão, Adília Moutinho, Museu Monográfico de Conimbriga - Colecções, p. 131, n. ${ }^{\circ}$ 404.4. Instituto Português de Museus, Lisboa, 1994.

$17^{211}$

Séc.Id.C.

Natureza: ágata; Cor: rosada e translúcida, com matizes mais claros

Forma: oval; Faces: planas, com bordos biselados

Dimensões: $12,5 \mathrm{~mm}$ X $15 \mathrm{~mm}$ X $2 \mathrm{~mm}$;

Estado de conservação: bom; Número de inventário: 67.591

Motivo:

BOVÍDEO

Bovídeo estante, de perfil à esquerda, olhando de frente para o observador. Linha de solo.

\section{Paralelos:}

Bourges, Guiraud, H. (1974), p. 221, n. 2, fig. 2; Guiraud,H. (1988), p. 167 , est. XLVI, n. ${ }^{\circ} 676$

Luni, Sena Chiesa, G. (1978), p. 115-116, est. XVIII, n. ${ }^{\circ}$ s 128 e 129

Aquileia, Sena Chiesa, G. (1966), p. 347, est. LII, n. ${ }^{\circ} 1032$

Dalmácia, Middleton, S. H. (1991), p. 117, n. ${ }^{\circ} 210$

Gadara, Henig, M. e Whiting, M. (1987), p. 34, n. ${ }^{\circ} 352$

Madrid, Casal Garcia, R. (1991), p. 166, n. ${ }^{\circ} 390$

Bucareste, gramatopol, M. (1974), p. 78, est. XXV, n. ${ }^{\circ} 513$

Haia, MaAskant-Kleibrink, M. (1978), p. 227-228, n. ${ }^{\circ} 560$

${ }^{210}$ Neverov, O., 1976, n. ${ }^{\circ}$ 100; Richter, G., 1971, n. ${ }^{\circ} 325$; Sena Chiesa, G., 1966, n. $^{\circ} 719$. 
Viena, Zwierlein-Diehl, E. (1991), p. 94, est. 39, n. ${ }^{\circ} 1856$; est. 40, n. ${ }^{\circ} 1858$

S. Petersburgo, Neverov, O. (1988), p. 88, n. ${ }^{\circ} 67$

Malibu, SPIER, J. (1992), p. 116, n. ${ }^{\circ} 298$

? (paradeiro desconhecido?), Furtwàngler, A. (1900), p. 218, est. $\mathrm{XLV}, \mathrm{n} .{ }^{\circ} 8$.

O aparecimento de bovídeos na Arte 211212 e nos cunhos monetários romanos insere-se na corrente idílica que, tal como na literatura, se desenvolveu na época de Augusto. Se bem que, em certos casos, ele assuma claros objectivos de propaganda política. Assim deveria ter acontecido nas moedas de Vespasiano, em que se procuraria simbolizar o programa da dinastia flávia para o restabelecimento da prosperidade agrícola da Itália.

Em Glíptica, onde aparecem já nos Séc. VI213, V e IV a. C 214215 , os bovídeos foram um tema muito difundido, embora repetitivo. Isolados (caminhando, deitados ou estantes), em certas variantes a sua representação está muito próxima da das paisagens campestres das pinturas murais romano-campanianas: bebendo de um vaso ${ }^{213}$; pastando, por vezes sob uma árvore (um tipo frequentíssimo, de que é também exemplo um entalhe inédito, proveniente do Alentejo) ${ }^{216}$; amamentando uma cria $^{217}$ (um motivo que remonta ao Séc. V a. C. $\left.{ }^{218}\right)$; lutando ${ }^{219}$ ou descansando à sombra de uma árvore cujos

211 Encontrado em 1967, durante as escavações luso-francesas, no nível de construção do forum flávio.

212 Sob a forma de estatuetas ou em relevos, mosaicos, pinturas e sarcófagos

(inclusive, cristãos, do Séc. Ill d. C.).

213 BOARDMAN, J., 1968, n. ${ }^{\circ}$ 104; NEVEROV, O., 1976, n. ${ }^{\circ} 15$.

214 Middleton, J. H., 1969, n. ${ }^{\circ}$ s 13 e 14; MiddLeton, S. H., 1991, n. ${ }^{\circ}$;; MARSHALL, F. H., 1907, n. ${ }^{\circ} 353$.

215 KruG, A., 1978, n. ${ }^{\circ}$ 17; ZWIERLEIN-DieHL, E., 1991, n. ${ }^{\circ}$ 1857; CASAL GARCIA, R., 1991, n. ${ }^{\circ}$ 104; SENA CHIESA, G., 1966, n. ${ }^{\circ} 1034$.

216 KRUG, A., 1980, n. ${ }^{\circ}$ 213; LIPPOLD, G., 1922, est. XCI, n. ${ }^{\circ}$ 1; ZWIERLEIN-DIEHL, E., 1991, n. ${ }^{\circ}$ s 1850; 1857-1860; MANDEL-ElzINGA, U., 1985, n. ${ }^{\circ}$ 40; CASAL GARCIA. R., 1991, n. ${ }^{\circ}$ s 103; 106; 107; 143; RICHTER, G., 1956, n. ${ }^{\circ}$ s 510-511; MAASKANT-KLEIBrinK, M., 1978, n. ${ }^{\circ}$ s 412 e 419; MARShall, F. FL, 1907, n. ${ }^{\circ}$ 1321; SENA ChIESA, G., 1966, n. ${ }^{\circ}$ s 1041; 1044-1045; GramATOPOL, M., 1974, n. ${ }^{\circ}$ 515; SternBERG, F., 1980, n. ${ }^{\circ} 771$; HAUTECOEUR, M. L., 1910, n. ${ }^{\circ} 124$.

2D KRUG,A., 1980, n. ${ }^{\circ}$ 214; ZWIERLEIN-DIEHL, E., 1991, n. ${ }^{\circ}$ s 1851-1852; CASAL GARCIA, R., 1991, n. ${ }^{\circ}$ s 105 e 391; RICHTER, G., 1956, n. ${ }^{\circ} 513$; MAASKANT-KLEIBRINK, M., 1978, n. ${ }^{\circ}$ s 176-177; SENA CHIESA, G., 1966, n. ${ }^{\circ} 1046$; ZWIERLEIN-DieHL, E., 1991, n. ${ }^{\circ} 1853$; GramatOPOL, M., 1974, n. ${ }^{\circ} 512$.

218 NeVEROV, O., 1976, n. ${ }^{\circ} 18$.

219 SENA CHIESA, G., 1966, n. ${ }^{\circ}$ s 1038; 1048-1049.

Conimbriga, 40 (2001) 141-197 
ramos, não raro, acompanham o contorno da pedra'220 (uma representação típica das gemas augustanas, que tem na sua base motivos pastoris e paisagísticos de tradição tardo-helenística).

Um curioso motivo é aquele em que uma junta de bois puxa um arado conduzido por um personagem masculino. Tema de tradição etrusca, frequente nos cunhos monetários da época de Trajano e presente também em moedas hispânicas (concretamente, de Caesar Augusta), poderá, na opinião de Raquel Casal Garcia (1991, p. 108), aludir à fundação de uma cidade (inauguratio). Neste caso, a figura humana simbolizaria o áugure traçando o sulcus primigenius para delimitação do seu perímetro 221 .

Mas, se o touro é sobreposto por uma estrela, a sua representação deveria ter tido um significado astrológico ${ }^{222}$. E se o artista colocou uma coroa de hera em volta do seu corpo, ele deveria ter tido um simbolismo religioso, já que foi transformado em touro dionisíaco ${ }^{223}$.

\section{Bibliografía:}

alarcão, J.; etienne, R.; alarcão, A. e ponte, S., Fouilles de Conimbriga, vol. VII, p. 135 e 139, n. ${ }^{\circ}$ 193, est. LIX, 2, 193. Paris, 1979

alarcão, A. M. e Ponte, S., Colecções do Museu Monográfico de Conimbriga - Catálogo, p. 95, n. ${ }^{\circ}$ 404.2. (fig. na pág. 72, n. ${ }^{\circ}$ 17). Coimbra, 1984

Alarcão, Adília Moutinho, Museu Monográfico de Conimbriga Colecções, p. 131, n. ${ }^{\circ}$ 404.2. Instituto Português de Museus, Lisboa, 1994.

Natureza: nicolo;

Cor: azul escuro sobreposto por tom acinzentado

Forma: oval (engastado num anel em ouro ${ }^{225}$ )

220 Furtwàngler, A., 1900, est. XLV, n. ${ }^{\circ}$ 2; CASAl Garcia, R., 1991, n. ${ }^{\circ} 107$; Guiraud, H., 1996, n. ${ }^{\circ}$ 43; Guiraud, H., 1988, n. ${ }^{\circ}$ 681; MAASKANT-KLEIBrinK, M., 1978, n. ${ }^{\circ}$ S 413 e 559; SENA CHIESA, G., 1966, n. ${ }^{\circ}$ s 1039; 1042-1043; ZWIERLEIN-DIEHL, E., 1991, n. ${ }^{\circ} 1855$; HENIG-WHITING, 1987, n. $^{\circ} 353$.

221 Casal Garcia, R., 1991, n. ${ }^{\circ} 133$.

222 Krug, A., 1980, n. ${ }^{\circ}$ 423; MAaskant-KLeibrinK, M., 1978, n. ${ }^{\circ}$ 150; SenA

ChiesA, G., 1966, n. ${ }^{\circ}$ s 1022-1023.

223 RICHTER, G., 1971, n. ${ }^{\circ} 715$.

224 Tendo sobretudo em conta o tipo do anel em que está engastado.

225 O anel foi encontrado em Junho de 1995, sob o mosaico da sala C 28 da Casa de Cantaber. Numa troca de impressões, o Dr. Virgilio Hipólito Correia (actual director do Museu de Conimbriga, testemunha do seu achado) manifestou a seguinte opinião: "o seu achado é fruto de ocultação intencional no mosaico. Tal ocultação apenas será 
Faces: planas, com perfil de nicolo;

Dimensões: $8 \mathrm{~mm} \mathrm{X} 10 \mathrm{~mm}$ X $3 \mathrm{~mm}^{226}$

Estado de conservação: fractura na base, que se prolonga pelo bordo e topo superior da mesa sem, contudo, atingir a parte gravada

Número de inventário: 95.1.

Motivo: (gravura do molde)

\section{PAPAGAIO}

Papagaio de perfil à esquerda, frente a um ramo com folhas. Linha de solo.

\section{Paralelos:}

Aquileia, Sena Chiesa, G. (1966), p. 387, est. LXVI, n. ${ }^{\circ} 1305$.

Os papagaios de cor verde 227 que, a partir do Séc. I a. C., abundaram em Roma, eram provenientes da India ${ }^{228}$. Facilmente reconhecíveis pela cauda arqueada e pelo colar de penas em volta do pescoço (o torques), constituiram um importante tema artístico. É frequente a sua gravação em túmulos ${ }^{229} \mathrm{e}$ páteras $^{230}$, o seu aparecimento sob a forma de estatuetas em bronze e a sua retratação em pinturas murais ${ }^{231}$ e $\operatorname{mosaicos}^{232}$. Mas, muito embora tais representações talvez apenas tivessem tido um mero papel decorativo, o facto de, em certos exemplares glípticos, eles segurarem no bico algo que Gisela Richter e Sena Chiesa interpretam como um par de címbalos, faz pensar na sua eventual ligação a Baco. Outros autores, porém, vêem nesse elemento um par de cerejas, tanto mais que, nalguns casos, é bem visível a folhagem.

explicável se tiver ocorrido com a casa em fase de abandono ou, pelo menos, em fase de não voltar a sofrer reparações”.

226 Foi possível colher estes dados porque a pedra estava solta, aquando do seu estudo inicial.

227 Não há, nos autores latinos, quaisquer referências aos papagaios cinzentos, de origem africana.

228 Segundo Élio, os brâmanes, atribuiam-lhes um carácter sagrado pela sua capacidade de imitar a fala humana.

229 Como, em Roma, no túmulo de Marcus Clodius Hermes e na catacumba de Domitilla.

230 É o caso de uma pátera de Lâmpsaco, em que é ladeado por uma figura personificando a índia.

231 Entre essas pinturas, destacam-se uma na Casa de Lívia (no Palatino) e outra proveniente de Pompeia (actualmente no Museu Britânico), em que se vê um papagaio caminhando por entre cerejas.

232 Como em Pompeia, Pérgamo, El-Djem e Antioquia. 
Muito popular em gemas, o papagaio, símbolo do riso e da felicidade, surge-nos ora como figura isolada (pousado na linha de solo ${ }^{233}$ ou voando ${ }^{234}$ ) ora associado a elementos diversos: uma estrela ${ }^{235}$; um conjunto de máscaras, formando um cacho de uvas $^{236}$; objectos simbólicos (kantharos e caduceu ${ }^{237}$, $\operatorname{ara}^{238}$, vaso ${ }^{239}$, taça ${ }^{240}$, cesto ${ }^{241}$, globo ${ }^{242}$, cornucopia ${ }^{243}$, um par de címbalos ou de cerejas ${ }^{244}$ ); símbolos (<dextrarum junctio ${ }^{245}$ ); plantas $\left(\right.$ espiga $^{246}$ e papoila $^{247}$, ramo ${ }^{248}$, árvore ${ }^{249}$, cerejas ${ }^{250}$ ); animais (borboleta ${ }^{251}$, minhoca ${ }^{252}$, coelho ${ }^{253}$, formiga ${ }^{254}$ ) e objectos (bigas ${ }^{255}$ ).

Relativamente a este motivo de Conimbriga, há uma ligeira variante, bastante mais frequente, em que o vemos pousado no próprio ramo que vai debicando 256 .

233 Casal Garcia, R., 1991, n. ${ }^{\circ}$ 434; Sena Chiesa, G., 1966, n. ${ }^{\circ}$ 1304; ZWIERLein-DIEHL, E., 1991, n. ${ }^{\circ} 2744$; BREGLIA, L., 1941, n. ${ }^{\circ}$ S 578; 582.

234 RICHTER, G., 1956, n. $^{\circ} 526$.

233 MARShall, F. H., 1907, n. ${ }^{\circ} 1168$ e Henig, M. 1974, n. ${ }^{\circ} 687$.

236 MAASKANT-KLEIBRINK, M., 1978, n. ${ }^{\circ} 716$.

237 HeNig-Whiting, 1987, n. ${ }^{\circ} 317$.

238 Casal Garcia, R. e Chaves Tristan, F., 1995, n. 27.

239 Guiraud, H., 1988, n. $^{\circ} 834$.

240 CASAl Garcia, R., 1991, n. ${ }^{\circ}$ 433; ZWIERLEIN-Diehl, E., 1991, n. ${ }^{\circ} 1970$.

241 SENA CHIESA, G., 1978, n. ${ }^{\circ}$ 165; ZWIERLEIN-DieHL, E., 1991, n. ${ }^{\circ}$ s 1782 e 1969.

242 ZWIERLEIN-DIEHL, E., 1991, n. ${ }^{\circ} 1970$.

243 ZWIERLEIN-DieHL, E., 1991, n. ${ }^{\circ}$ s 1969 e 1970; GuIRAUD, H., 1973, n. ${ }^{\circ} 9$.

244 ZWIERLEIN-DieHL, E., 1991, n. ${ }^{\circ}$ S 1963-1964; 1966-1967; CASAL GARCIA, R., 1980, est. II, n. ${ }^{\circ} 4$ c-d; Casal Garcia, R., 1995, p. 211; CASAl Garcia, R. e Chaves Tristan, F., 1995, n. ${ }^{\circ}$ 39; Richter, G., 1956, n. ${ }^{\circ}$ 523; Guiraud, H., 1996, n. ${ }^{\circ} 48$; MAASKANT-KLEIBRINK, M., 1978, n. ${ }^{\circ}$ S 565; 723; MARSHALl, F. H., 1907, n. ${ }^{\circ} 1357$; Sena Chiesa, G., 1966, n. ${ }^{\circ}$ 1297-1300; Sena Chiesa, G., 1978, n. ${ }^{\circ}$ 143; HeniG, M., 1974, n. ${ }^{\circ}$ s 672-673; POPOVIC, I., 1989, n. ${ }^{\circ} 66$.

245 Sena Chiesa, G., 1978, n. ${ }^{\circ 1} 165$ (para além de cornucopia e globo).

246 GuiRAud, H., 1998, n. ${ }^{\circ} 18$; JoHNs, C., 1977, n. ${ }^{\circ}$ s 204-205.

247 ZWIERLEIN-DIEHL, E., 1991, n. ${ }^{\circ}$ S 1969-1970; 2037.

248 ZWIERLEIN-DIEHL, E., 1991, n. ${ }^{\circ} 1968$.

249 ZWIERLEIN-DIEHL, E., 1991, n. ${ }^{\circ} 1962$.

250 ZWIERLEIN-DIEHL, E., 1991, n. ${ }^{\circ} 1965$.

251 ZWIERLEIN-DIEHL, E., 1991, n. ${ }^{\circ} 1784$.

232 RICHTER, G., 1956, n. ${ }^{\circ} 524$.

233 ZWIERLEIN-DIEHL, E., 1991, n. ${ }^{\circ} 1782$.

${ }^{254}$ ZWIERLEIN-DieHL, E., 1991, n. $^{\circ} 1783$ (papagaio fazendo de auriga, conduzindo biga de formigas).

233 ZWIERLEIN-DieHL, E., 1991, n. ${ }^{\circ} 1783$; SENA CHIESA, G., 1966, n. ${ }^{\circ}$ s 1360-1361 (papagaios como animais de tiro).

${ }^{236}$ KrUG, A., 1980, n. ${ }^{\circ}$ s 54 e 436; CASAl Garcia, R., 1991, n. ${ }^{\circ}$ 435; GuIRAUd,

Conimbriga, 40 (2001) 141-197 
Bibliografía:

Inédito.

Natureza: pasta vítrea (imitação do nicolo);

Cor: beringela sobreposto por azul claro

Forma: oval; Faces: planas, com perfil de nicolo

Dimensões: $11 \mathrm{~mm} \mathrm{X} 13 \mathrm{~mm} \mathrm{X} \mathrm{2,5} \mathrm{mm}$

Estado de conservação: face superior deteriorada, com picado miúdo Número de inventário: A 423

Motivo:

\title{
PEIXE
}

Peixe nadando para a direita.

\author{
Paralelos: \\ Vieille-Toulouse, Guiraud, H. (1988), p. 177, est. LII, n. ${ }^{\circ} 784$ \\ Aquileia, Sena Chiesa, G. (1966), p. 399, est. LXXI, n. ${ }^{\circ} 1402$ \\ Mainz, KrUg, A. (1978), p. 490-491, n..$^{\circ} 10$, est. 50,n. ${ }^{\circ} 10$ \\ Byblos, Marshall, F. H. (1907), p. 88, n. ${ }^{\circ} 517$ \\ Asia Menor, SPIER, J. (1992), p. 143, n. 396 \\ Nápoles, Breglia, L. (1941), p. 73, n. ${ }^{\circ} 577 ;$ p. 74, n. ${ }^{\circ} 587$ \\ Londres, Marshall, F. H. (1907), p. 85, n. ${ }^{\circ} 498$; p. 92 , n. ${ }^{\circ} 543$ \\ Haia, MaAsKant-Kleibrink, M. (1978), p. 284 , n. ${ }^{\circ} 798$ \\ Bucareste, gramatopol, M. (1974), p. 80, est. XXVI, n. 544.
}

Criados em vivaria oupiscinae, os peixes, fundamentais na alimentação e na economia romanas 257258 , despertavam já um interesse científico assinalável, como se deduz do catálogo de Ausonius em que são descritas, pormenorizadamente, as catorze espécies do rio Mosela. Mas era também manifesto o seu interesse artístico, pelo belo efeito decorativo que proporcionavam. Sobretudo

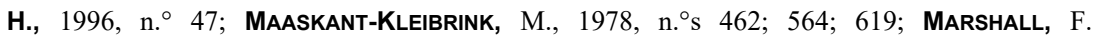
H., 1907, n. ${ }^{\circ}$ s 448 e 487; Sena Chiesa, G., 1966, n. ${ }^{\circ}$ s 1301-1303; Henig-Whiting, 1987, n. ${ }^{\circ}$ s 377-378; HENIG, M., 1974, n. ${ }^{\circ}$ s 685 e 686.

257 Proveniente de escavações antigas, antes da criação do Museu Monográfico de Conimbriga, onde deu entrada em Junho de 1962, fez parte do acervo do Museu Nacional Machado de Castro.

258 Tenha-se, por exemplo, em conta a importância do garum. Sobretudo o de Cartagena que, segundo Plínio, era o melhor e o mais caro. 
em mosaicos, onde abundam as cenas de pesca, de portos e de lutas entre animais marinhos (em especial, entre o polvo e a moreia e, por vezes, também a lagosta).

Contudo, no pensamento religioso pagão, o peixe tinha uma conotação funerária, simbolizando, na arte tumular, os mortos no Além ${ }^{259}$. Talvez que, segundo Toynbee ${ }^{260}$, esta sua associação à imortalidade tenha contribuído para popularizar, na mentalidade, arte e epigrafia cristãs, o significado da palavra grega Tx@us como símbolo eucarístico e como acróstico de Irjaõos Xpiaxós, 0sõu 'mós acoxfjp (Jesus Cristo, filho de Deus, Salvador).

Por tudo isto se compreende que, também em Glíptica, ele tenha sido um tema popular. E não apenas como motivo isolado mas também associado a outros animais (reais ou míticos: camarão ${ }^{261}$, caranguejo ${ }^{262}$, choco ${ }^{263}$, murex $^{264}$, elefante ${ }^{265}$, ave ${ }^{266}$, capricórnio ${ }^{267}$ ) ou a objectos simbólicos (leme ${ }^{268}$, cornucopia ${ }^{269}$ ).

Nalguns casos, porém, o seu simbolismo cristão é bem reforçado pela presença, no campo da gema, de uma âncora (motivo simbólico, de origem cristã, muito frequente no Séc. IV d. C. $)^{270}$ ou de uma inscrição ${ }^{271}$.

\section{Bibliografía:}

Cardozo, Mário. "Pedras de anéis Romanos encontradas em Portugal". Revista de Guimarães, LXXII, n. ${ }^{\circ} \mathrm{s} 1$ e2,p. 155-160,n. ${ }^{\circ} 5$ (interpretado como "um golfinho"). Guimarães, 1962

França, Elsa Ávila. "Anéis, braceletes e brincos de Conimbriga”. Conimbriga, VIII, p. 42, n. ${ }^{\circ}$, est. V, n. ${ }^{\circ}$ 4. Coimbra, 1969.

259 No Mausoléu de Ghirza, em Tripoli, oito peixes nadam em círculo e mordiscam uma roseta central (emblema da vida além-túmulo).

260 In Animals in Roman Life and Art. Londres, 1973, p. 212.

261 Casal Garcia, R., 1991, n. ${ }^{\circ}$ 458; Casal Garcia, R. e Chaves Tristan, F., 1995, n. 25; Guiraud, H., 1988, n. 787; Marshall, F. H., 1907, n. 445; HeNig, M., 1974, n. ${ }^{\circ} 717$; Sena Chiesa, G., 1966, n. ${ }^{\circ} 1393$; Zwierlein-DieHL, E., 1991, n. 1791.

262 ZWIERLEIN-DieHL, E., 1991, n. ${ }^{\circ} 1789$; MAASKANT-KLEIBRINK, M., 1978, n. ${ }^{\circ} 234$.

263 GuiraUd, H., 1988, n. $^{\circ} 785$.

264 Sena Chiesa, G., 1966, n. ${ }^{\circ} 1406$; ZWierlein-Diehl, E., 1991, n. ${ }^{\circ} 1790$.

265 BOARDMAN, J., 1968, n. ${ }^{\circ} 57$.

266 RICHTER, G., 1956, n. ${ }^{\circ}$ 538; GRAMATOPOL, M., 1974, n. ${ }^{\circ} 573$.

267 Gramatopol, M., 1974, n. ${ }^{\circ} 573$.

268 RICHTER, G., 1956, n. ${ }^{\circ} \mathrm{s} 536$ e 538.

269 GRAmatopol, M., 1974, n. ${ }^{\circ} 573$.

270 LoPeZ de LA ORDEN, D., s. d., n. ${ }^{\circ}$ 194; MAASKANT-KLeibrinK, M., 1978, n. ${ }^{\circ}$ 1074; Sena Chiesa, G., 1966, n. ${ }^{\circ} 1399$; Casal Garcia, R., 1991, n. 474.

271 KRUG, A., 1980, n. ${ }^{\circ} 81$; GUIRAUd, H., 1988, n. ${ }^{\circ} 783$. 
Natureza: cornalina;

Cor: avermelhada

Forma: rectangular (engastado num anel em prata, com aro de secção em $\mathrm{D}^{272}$ )

Mesa: plana;

Dimensões: $5 \mathrm{~mm}$ X $9 \mathrm{~mm}$

Estado de conservação: bom;

Número de inventário: 63.30

Motivo:

\section{INSCRIÇÃO}

Inscrição, em positivo, em que se lê HAVE ${ }^{273}$.

\section{Paralelos:}

Barnay, GUIRAUD, H. (1988), p. 192, est. LXI, n. ${ }^{\circ} 923$ (AVE)

Vendeuil-Caply, GUIRAUD, H. (1988), p. 192, est. LXI, n. 928 (HAVI)

Madrid, CASAL GARCIA, R. (1991), p. 185, n. ${ }^{\circ} 487$ (AVE)

Londres, WALTERS, H. B. (1926), p. 349, n. ${ }^{\circ} 3714$ (HAVE)

Sobretudo nos finais do Império, é frequente os entalhes apresentarem fórmulas ou frases dirigidas ao seu possuidor. Entre elas, as de saudação, como a que vemos no acima descrito e as suas variantes AVE e HAVI, igualmente comuns em anéis ${ }^{274}$.

Em certos casos, porém, esta fórmula é acompanhada de um voto de felicidade: AVE EVTYCHA ${ }^{275}$. Ou de uma expressão carinhosa: AVE MEA VITA $^{276}$. Ou é dirigida a uma divindade: HAVE ROMA ${ }^{277}$.

Curiosamente, verificamos que, nas suas diversas variantes, é uma fórmula cuja presença tem uma certa predominância na região mediterrânica.

272 Encontrado em terras remexidas, nas traseiras da Casa dos Esqueletos, a nascente da sala 18 .

273 Imperativo do verbo latino aveo, HAVE está também presente em várias inscrições do C.I.L.: n. ${ }^{\circ} 1092$, de Alcalá del Rio; n. ${ }^{\circ} 1871$, de Cádis; n. ${ }^{\circ} 3178$, de Albarracin; n. ${ }^{\circ}$ 3686, de Palma de Maiorca; n. ${ }^{\circ}$ s 4290, 4419, 4445 e 6074, de Tarragona.

274 Marshall, F. H., 1907, n. ${ }^{\circ}$ 644; FrançA, E. Á., 1969, p. 34, n. ${ }^{\circ}$ 58, est. II, n. $^{\circ} 58$ (anel em bronze, com aro de secção em D, encontrado em Conimbriga, nas Grandes Termas do Sul).

275 Guiraud, H., 1988, n. ${ }^{\circ} 924$.

276 GuIRAUD, H., 1988, n. ${ }^{\circ} 706$.

277 Furtwàngler, A., 1900, est. XXV, n. ${ }^{\circ} 34$.

Conimbriga, 40 (2001) 141-197 


\section{Bibliografía:}

alarcão, A. M. e Ponte, S., Colecções do Museu Monográfico de Conimbriga - Catálogo, p. 95, n. ${ }^{\circ}$ 403.17. Coimbra, 1984

Alarcão, Adília Moutinho, Museu Monográfico de Conimbriga - Colecções, p. 130, n. ${ }^{\circ}$ 403.17. Instituto Português de Museus, Lisboa, 1994.

Natureza: pasta vítrea (imitação do nicolo)

Cor: camada inferior azul sobreposta por camada esbranquiçada e com patine

Forma: oval (engastado num anel em bronze ${ }^{279}$ );

Dimensões: $14 \mathrm{~mm}$ X $11 \mathrm{~mm}$

Estado de conservação: incompleto (a parte superior da mesa está mutilada)

Número de inventário: 68.677

Motivo: não identificável, dada a mutilação da mesa.

\section{Bibliografía:}

alarcão, J.; Etienne, R.; Alarcão, A. e Ponte, S., Fouilles de Conimbriga, vol. VII, p. 135 e 138, n. ${ }^{\circ}$ 183, est. XXXII, 183. Paris, 1979.

Natureza: ?;

Cor: ?;

Forma: quase circular;

Mesa: plana?;

Base: ?;

Dimensões: ?;

Estado de conservação: quando publicada, estava completa, embora deteriorada

278 A cronologia indicada tem por base o tipo de anel (cf. GuIRAUD, H., 1988, est. LXVI, n. ${ }^{\circ} 712$ ).

279 Encontrado no nível de destruição do habitat bárbaro - um horizonte cuja cronologia nunca poderá ser anterior a finais do Séc. V d. C. e no qual foram encontrados materiais de diferentes épocas: sigillata hispânica do Séc. I d. C.; vidro do Séc. Ill d. C.; moedas do Séc. III (Galieno, 267-268) ao Séc. IV d. C. (Constancio II e Juliano César, 355-361); sigillata clara e cerâmica pintada dos Séc. IV-V d. C. 
Paradeiro actual: desconhecido?280

Motivo: não identificável na gravura que dele resta ${ }^{281}$.

\title{
Bibliografía:
}

Cardozo, Mário. "Pedras de anéis romanos encontradas em Portugal". Revista de Guimarães, LXXII, n. ${ }^{\circ}$ s 1 e 2, p. 155-160, n. ${ }^{\circ}$ 6. Guimarães, 1962.

\section{II - MOLDES:282}

\section{$23^{283}$}

\author{
Natureza: ?; \\ Cor: cinzenta ${ }^{284}$; \\ Forma: oval; \\ Mesa: plana, com os bordos cortados para fora \\ Dimensões do molde: $11 \mathrm{~mm} \mathrm{X} 7 \mathrm{~mm} \mathrm{X} \mathrm{c.} 1 \mathrm{~mm}$; \\ Estado de conservação: bom \\ Número de inventário: não vai ser atribuído ${ }^{285}$
}

280 Encontrada em escavações antigas, quando publicada, em 1962, fazia parte do acervo do Museu Nacional Machado de Castro. Todavia, não foi localizada nem no acervo desse Museu nem no de Conimbriga.

281 Mário Cardozo interpretou-o como uma flor de lótus. Mas, se observarmos com atenção a fotografia que dele resta, parece ver-se, do seu lado esquerdo, uma linha vertical que poderá corresponder a uma linha de solo.

282 Dos três exemplares que se seguem, apenas conhecemos os moldes, em lacre, executados no Séc. XIX. Oferecidos ao Museu de Conimbriga por António Sampaio Madahil, em 24/3/1999, haviam sido adquiridos a familiares de António Augusto Gonçalves. A ficha em que estão gravados diz, textualmente, o seguinte: "camafeus gravados em pedra cinzenta o I o, segundo a granat eram de anel achados na Conimbriga $0,1^{\circ}$ ofereci-o ao, Museu Machado de Castro o segundo pertence à família do Dr. Morna".

283 Na ficha supra-citada, com o seu molde em verde-escuro, refere-se que foi oferecido ao Museu Machado de Castro.

284 Assim é descrito na ficha em que está gravado. Curiosamente, o tema nele patente parece ter sido preferencialmente gravado em ametista (cf. MAASKANT-KLEIBRINK, M., 1978, p. 254, a propósito do n. ${ }^{\circ}$ 668. A este poderá acrescentar-se o exemplar do Museu Britânico, citado nos paralelos, que MARSHALL não identifica correctamente).

285 L 21 é o número atribuído à sua ficha de estudo, no Museu de Conimbriga.

Conimbriga, 40 (2001) 141-197 


\section{Motivo:}

\section{HERMES-MERCÚRIO EM REPOUSO}

Mercúrio, voltado à esquerda, sentado numa massa rochosa, na qual apoia a mão esquerda. Na mão direita, descaída, segura uma vara (o rhabdos). Linha de solo.

\section{Paralelos:}

Ibiza, Astruc, M. (1954), p. 120, n. ${ }^{\circ} 85$

Aquileia, Sena Chiesa, G. (1966), p. 144, est. X, n. ${ }^{\circ}$ s 195-196

Colónia, Krug, A. (1980), p. 220, est. 99, n. ${ }^{\circ} 255$

Silchester, HeNiG, M. (1974), p. 16, n. ${ }^{\circ} 63$

Ravena, MaIOLI, M. G. (1971), p. 27-28, n. ${ }^{\circ} 23$

Haia, MaAskant-Kleibrink, M. (1978), p. 213, n. ${ }^{\circ} 497$

Berlim, Furtwàngler, A. (1900), p. 216, est. XLIV, n. ${ }^{\circ} 64$

Londres, Marshall, F. H. (1907), p. 87, n. ${ }^{\circ} 509$ (interpretado como jovem com cana de pesca).

Como protector dos viajantes, Hermes-Mercúrio é quase sempre representado sentado numa massa rochosa, que simbolizaria o monte de pedras que delimitavam os caminhos de que era patrono já em tempos pré-helénicos. $\mathrm{Na}$ origem deste tipo, deverá estar uma obra escultórica bastante difundida (provavelmente da escola de Lisipo ou tardo-helenística), de que é exemplo uma estátua em bronze, proveniente de Herculano. Transposto, depois, para a glíptica helenística ${ }^{286}$, viria a constituir um tema muito popular em gemas romanas.

No caso concreto do molde acima descrito e dos paralelos citados, a presença do rhabdos, e não do caduceu, alude, provavelmente, à sua função de condutor das almas para o Além (.Hermes Psicopompo).

Contudo, o que predomina é o esquema em que segura o caduceu ${ }^{287}$. E, em certos casos, tendo, a seu lado, um Erote ${ }^{288}$ ou, aos pés, um animal que lhe estivesse associado - o galo ou o carneiro, este, por vezes, com uma palma na boca (um motivo sobretudo frequente a partir do Séc. II d. C. e que teria a ver com uma simbologia ctónica) $)^{289}$.

286 FURTWÀnGLER, A., 1900, est. XXXI, n. ${ }^{\circ} 36$.

287 KRUG, A., 1980, n. ${ }^{\circ}$ 5; CASAl Garcia, R., 1991,n. ${ }^{\circ}$ s 207 e 209; Richter, G., 1956, n. ${ }^{\circ}$ 288; Richter, G., 1971, n. ${ }^{\circ}$ s 114-115; GuIRAUD, H., 1988, n. ${ }^{\circ}$ s 179-180; MAASKANT-Kleibrink, M., 1978, n. ${ }^{\circ}$ 496; Henig, M., 1974, n. ${ }^{\circ}$ 54; Breglia, L., 1941, n. ${ }^{\circ}$ 520; GrAMATOPOL, M., 1974, n. ${ }^{\circ} 221$; HeNIG, M., 1975, n. ${ }^{\circ} 39$; HAUTECOEUR, M. L., 1910, n. ${ }^{\circ} 89$.

288 MAASKANT-KLEIBRINK, M., 1978, n. ${ }^{\circ} 584$.

289 KrUG, A., 1980, n. ${ }^{\circ}$ s 1 i 1 e 253 ; TrUMMER, R., 1981/82, n. ${ }^{\circ} 16$; CASAL

Garcia, R., 1991, n. ${ }^{\circ}$ S 208; 210; Richter, G., 1956, n. ${ }^{\circ}$ 289; MiddLEton, S. H., 1991, 
Mas pode também aparecer sentado numa base, com o caduceu na sua frente apoiado num globo ${ }^{290}$, ou numa espécie de $\operatorname{altar}^{291}$.

\section{Bibliografía:}

Inédito.

\section{2}

Natureza: ?;

Cor: cor da granada?293;

Forma: oval;

Mesa: plana

Dimensões do molde: $13 \mathrm{~mm} \mathrm{X} 11 \mathrm{~mm} \mathrm{X} \mathrm{c.} 2 \mathrm{~mm}$;

Estado de conservação: bom

Número de inventário: não vai ser atribuído 294

\section{Motivo:}

\section{CENTAURO}

Figura híbrida (meio cavalo-meio homem), caminhando para a direita. Barbada e com coroa na cabeça, segura, na mão esquerda, recuada, um tirso, que pousa obliquamente no ombro do mesmo lado, e, na direita, uma bolsa. O exemplar original, pela correcção que o molde denota, deveria inspirar-se no gosto neo-classicista da época de Augusto.

\section{Paralelos:}

Aquileia, Sena Chiesa, G. (1966), p. 194, n. ${ }^{\circ} 418$.

Tunis, Hautecoeur, M. L. (1910), p. 342, n. ${ }^{\circ} 68$

Seres monstruosos 295 , habitantes de montes e florestas e de costumes brutais (à excepção de Quíron e Folo, descritos como bondosos, hospitaleiros

n. ${ }^{\circ}$ 60; Guiraud,H., 1988, n. ${ }^{\circ}$ 185; MaASKant-KleibrinK,M., 1978, n. ${ }^{\circ}$ s 498 e 668; Sena Chiesa, G., 1966, n. ${ }^{\circ}$ s 201-204; Maioli, M. G., 1971, n. ${ }^{\circ} 24$; Hautecoeur, M. L., 1910, n. ${ }^{\circ}$ 88; Righetti, R., 1955, n. ${ }^{\circ}$ 14; Casal Garcia, R. e Chaves Tristan, F., 1995, n. ${ }^{\circ} 54$.

290 GUIRAUD, H., 1988, n. $^{\circ} 188$.

291 MaASKANT-KLEIBrinK, M., 1978, n. ${ }^{\circ} 583$.

292 Na ficha supra-citada, com o seu molde em lacre vermelho, diz-se que pertencia à família do Dr. Morna.

293 Na ficha em que está colado o seu molde, a pedra é descrita como sendo "a granat".

294 M 22 é o número atribuído à sua ficha de estudo, no Museu de Conimbriga.

295 Tomando-os como modelos, surgiram também representações de outros seres híbridos, meio homens e meio peixes: os ictiocentauros.

Conimbriga, 40 (2001) 141-197 
e amigos dos homens), os Centauros aparecem na mitologia grega raptando jovens ou violando-as, lutando com Héracles ou contra os Lápidas da Tessália (neste caso, um episódio cujo significado é bem preciso: o da luta da civilização contra a barbárie).

Tema já presente em gemas do Séc. VI a. C. ${ }^{296}$ e helenísticas ${ }^{297}$, foi muito popular entre os Romanos, quer em cunhos monetários ${ }^{298}$ quer no reportório decorativo de origem helenística quer noutras formas artísticas ${ }^{299}$.

No caso concreto da Glíptica, nem sempre o Centauro, como figura isolada, apresenta os mesmos atributos. Por veses, é representado segurando um ramo (abeto?), entre os braços ${ }^{300}$ ou apenas na mão esquerda ${ }^{301}$ ou, para além dele, um corno, donde parece beber ${ }^{302}$. Outras, segura um tirso (do qual pende um cesto de fruta e uma lebre morta) e um cesto de fruta ${ }^{303}$ ou, em vez do tirso, um pedum ${ }^{304}$.

Por outro lado, também a própria postura difere, já que pode aparecer com a cabeça voltada para trás ${ }^{305}$, tocando flauta ${ }^{306}$, dançando na ponta dos "pés"307, disparando uma flecha ${ }^{308}$ ou fugindo de uma outra, disparada por Héracles, que quase o atinge nas costas ${ }^{309}$.

Mas, é frequente, estar associado a figuras animais (afrontando um leão ${ }^{310}$ ) ou mitológicas: lutando com Héracles ${ }^{311}$, com os Lápidas ${ }^{312}$, com um

296FURTWÀngLER, A., 1900, est. VIII, n. ${ }^{\circ} 6$ e NEVEROV, O., 1976, n. ${ }^{\circ} 13$;

GRAMATOPOL, M., 1974, n. ${ }^{\circ} 29$.

297 GRAMATOPOL, M., 1974, n. ${ }^{\circ} 64$.

298 ImHOOF-Blumer, F. e Keller, O., 1972, est. XI, n. ${ }^{\circ} 44$.

299 A título de exemplo, cite-se um cálice em prata, patente no Museu de Nápoles.

300 Sena ChIESA, G., 1966, n. ${ }^{\circ} 419$.

301 Richter, G., 1956, n. ${ }^{\circ}$ 399; HeNIG-WhitinG, 1987, n. ${ }^{\circ}$ 388; KrUG, A., 1975,

n. ${ }^{\circ}$ 19; LOPEZ DE LA ORDEN, D., 1989, n. ${ }^{\circ} 36$ e LOPEZ DE LA ORDEN, D., s. d., n. ${ }^{\circ} 205$.

302 HeNIG-Whiting, 1987, n. ${ }^{\circ} 389$.

303 MAASKANT-KLEIBRINK, M., 1978, n. ${ }^{\circ} 397$.

304 RighetTI, R., 1955, n. ${ }^{\circ} 34$.

305 Sena Chiesa, G., 1966, n. ${ }^{\circ}$ 420; HeniG, M., 1974, n. ${ }^{\circ}$ 657; FurTWÀNGLER, A., 1900, est. XVIII, n. ${ }^{\circ} 71$.

${ }^{396}$ KRUG, A., 1980, n. ${ }^{\circ}$ 144; RICHTER, G. 1971, n. ${ }^{\circ} 250$ (frente a duas figuras aladas tocando syrinx).

307 MAASKANT-KLEIBRINK, M., 1978, n. ${ }^{\circ} 927$.

308 HeNIG-WHITING, 1987, n. ${ }^{\circ}$ 390; ZWIERLEIN-DieHL, E., 1991, n. ${ }^{\circ} 2180$-b (tipo do signo astrológico do Sagitário).

309 FurTwÀngler, A., 1900, est. XIII, n. 30; LOPEZ DE LA ORdEN, D., s. d., n. ${ }^{\circ} 206$.

310 HeNIG, M., 1974, n. ${ }^{\circ} 656$.

311 KRUG, A., 1980, n. ${ }^{\circ} 327$.

Conimbriga, 40 (2001) 141-197 
guerreiro prostrado 312313 ou sendo montado por uma figura feminina (talvez raptada ou ligada à sua luta contra os Lápidas) ${ }^{314}$ ou por Eros ${ }^{315}$. Neste último caso, estamos perante um motivo de inspiração helenística, também presente em escultura, de que são exemplo o "Centauro de Aristeas", do Museu Capitolino, e o "Centauro com Eros", do Museu do Louvre.

Bastante, comum é também, a ligação de Quíron à figura lendária de Aquiles, a quem teria ensinado a tocar lira ${ }^{316}$. Tema igualmente frequente em lucernas, composições pictóricas (como uma pintura de Herculano) e relevos em mármore (como um exemplar do Museu Capitolino), talvez tivesse derivado de uma obra escultórica, provavelmente grega, que Plínio (Nat. Hist., XXXVI, 29) dizia existir em Roma, nos Saepta Julia, mas cujo autor se desconhece.

\title{
Bibliografía:
}

Inédito.

$25^{317}$

\author{
Natureza: ?; \\ Cor: ?; \\ Forma: oval; \\ Mesa: plana \\ Dimensões do molde: $9 \mathrm{~mm}$ X $6 \mathrm{~mm} \mathrm{X} \mathrm{c.} 1 \mathrm{~mm}$; \\ Estado de conservação: bom \\ Número de inventário: não vai ser atribuído ${ }^{318}$ \\ Motivo:
}

\section{ATLETA VENCEDOR DE CORRIDA}

Figura masculina correndo para a direita, com o braço direito recuado. Na mão esquerda, avançada, segura uma coroa de louros com

312 Marshall, F. H., 1907, n. ${ }^{\circ} 357$; Sena Chiesa, G., 1966, n. 717.

313 Sena ChiesA, G., 1966, n. ${ }^{\circ} 718$; KrUG, A., 1980, n. ${ }^{\circ} 329$.

314 HENIG, M., 1975, n. ${ }^{\circ} 75$.

315CASAL GARCIA, R., 1991, n. ${ }^{\circ}$ 75; MAASKANT-KLEIBRINK, M., 1978, n. ${ }^{\circ}$ 2 242; $375-376$.

316 MaAsKant-KleibrinK, M., 1978, n. ${ }^{\circ}$ 396; Sena Chiesa, G., 1966, n. ${ }^{\circ}$ s 737 -738; Richter, G., 1971, n. ${ }^{\circ}$ 286; KrUG, A., 1980, n. ${ }^{\circ}$ 328; GonZENBACH, V., 1952, n. ${ }^{\circ}$ 18; SPIER, J., 1992, n. ${ }^{\circ}$ 412; FURTWÀnGler, A., 1900, est. XLIII, n. ${ }^{\circ} 16$ e LIPPOLD, G., 1922, est. XL, n. ${ }^{\circ} 6$.

$31^{7}$ Molde em tom verde-claro, sem qualquer legenda relativa à pedra original.

318 K 20 é o número atribuído à sua ficha de estudo, no Museu de Conimbriga.

Conimbriga, 40 (2001) 141-197 
fitas pendentes. Frente à perna direita, está gravada a letra F. Não é visível linha de solo. $\mathrm{O}$ original deveria estar gravado em estilo classicista.

\section{Paralelos:}

Não identificados na bibliografia consultada.

São bastante numerosas, em Glíptica Romana, as representações de cenas desportivas (corridas de circo, combates corpo-a-corpo) e de atletas (corredor, discóbolo, gladiador, pugilista, auriga ${ }^{319}$ ), por vezes, raspando o corpo com um estrigilo, frente a uma palma fincada no solo, como acontece num exemplar proveniente, uma vez mais, do Alentejo ${ }^{320}$. Com origem na iconografia grega e correspondendo ao mundo real dos desportos então praticados ou à sua idealização, esses tipos irão persistir até ao Séc. IV d. C., reflectindo bem a importância do lema clássico "mente sã em corpo são".

O tipo do atleta-corredor não é, porém, dos mais frequentes. Correndo, sem qualquer outro atributo, é, aliás, um motivo extremamente raro $^{321}$. O que predomina, de facto, é a sua representação como vencedor de corrida: segurando apenas a palma, que pousa no ombro ${ }^{322}$, ou a palma e a $\operatorname{coroa}^{323}$ ou a palma e uma figura de Vitória ${ }^{324}$.

\section{Bibliografía:}

Inédito.

\section{BIBLIOGRAFIA}

Alarcão, Adília M. e Ponte, Sálete da (1984), Colecções do Museu Monográfico de Conimbriga. Catálogo, p. 95. Coimbra

AlarCão, Adília Moutinho (1994), Museu Monográfico de Conimbriga-Colecções, pp. 130-131. Instituto Português de Museus. Lisboa

319 Para além de dois exemplares inéditos, encontrados no Alentejo, cite-se um outro proveniente da villa de Freiria (Vide: CravinHo, G., 1993-1994, n. ${ }^{\circ}$ 2, fig. 2).

320 Cravinho, G., 2000, est. I, n. ${ }^{\circ} 5$.

321 CASAl Garcia, R., 1991, n. ${ }^{\circ} 369$.

322 MARShall, F. H., 1907, n. 1291 (designado por "Eros" com palma); FURTWÀNGLER, A., 1900, est. XXVIII, n. ${ }^{\circ} 2$.

323 Guiraud,H., 1988, n. ${ }^{\circ}$ 572; Sena Chies A, G., 1966, n. ${ }^{\circ}$ s 934-935; Parreira, R.-Vaz Pinto, C. 1980, n. 202 e Ponte, S., 1995, n. ${ }^{\circ} 227$; Casal Garcia, R., 1991, n. ${ }^{\circ} 372$; ZWIERLEIN-DiEHL, E., 1991, n. ${ }^{\circ} 1692$.

324 Sena Chiesa, G., 1966, n. ${ }^{\circ} 936$.

Conimbriga, 40 (2001) 141-197 
AlarCÃo, Jorge (1987), Portugal Romano. Editorial Verbo, 4a Edição. Lisboa

Alarcão, J.; Etienne, R.; Alarcão, A.; Ponte, S. (1979), Fouilles de Conimbriga, vol. VII, p. 133-139. Paris

Alfaro Giner, Carmen (1996), "Entalles y Camafeos de la Universitat de Valência". Estudis Numismátics Valencians, n. ${ }^{\circ} 7$. Valência

Astruc, Miriam (1958), "Catalogo Descriptivo de los Entalles Procedentes de Distintos Sitios de la Colonización oriental de la Península". Memorias de los Museos Arqueológicos Provinciales, XV, 1954. Madrid

Becatti, Giovanni (1955), Oreficerie Antichedalle Minoiche alie Barbariche. Roma

Berry, Burton Y. (1969), Ancient Gems from the Collection of Burton Y. Berry. Indiana University Art Museum Publication, I. Indiana

Bohrdman, John (1968), Engraved Gems - The Ionides Collection. Northwestern University Press. Londres

BOARDMAN, John (1975), Intaglios and Rings Greek, Etruscan and Eastern from a private collection. Thames and Hudson. Londres

Breglia, Laura (1941), Catalogo delle Oreficerie del Museo Nazionale di Napoli. Roma

CARDozo, Mário (1962), "Pedras de Anéis Romanos Encontradas em Portugal" Revista de Guimarães, LXXII, n. ${ }^{\circ}$ s 1-2, p. 155-160. Guimarães

CASAl GARCIA, Raquel (1979), "Algunos Entalles de la Colección "Blanco-Ciceron" (A Coruña)". Actas do XV Congresso de Arqueologia Nacional, p. 1107-1118 (Lugo, 1977). Zaragoza

Casal García, Raquel (1980), "Pedras de Anelo do Noroeste Peninsular". Gallaecia 6,p. 101-110. Universidade de Santiago de Compostela

Casal García, Raquel (1991), Colección de Glíptica del Museo Arqueológico Nacional (serie de entalles romanos), vols. I e II. Dirección General de los Museos Estatales. Madrid

CASAl GarcíA, Raquel (1995), “Anillos y Gemas Romanos en Galicia”. Arqueoloxia e Arte na Galicia Prehistórica e Romana. Monografias, 7, p. 205-214. Museu Arqueolóxico e Histórico de A Coruña

Casal García, Raquel e Chaves Tristan, Francisca (1995), "Problemática de la glíptica en España: estado de la cuestión”. PACT 23 - IV. 9 (separata). Rixensart (Bélgica)

Cravinho, Graça (1993-1994), “Algumas Peças da villa de Freiría (Cascais)”. Conimbriga, XXXII-XXXIII, p. 333-348. Coimbra

Cravinho, Graça (1997-1998), “A Colecção de Glíptica da Biblioteca Nacional”. LEITURAS, 2, p. 169-180. Lisboa

Cravinho, Graça (2000), "Introdução ao Estudo da Glíptica Romana". Arqueologia, n. ${ }^{\circ} 25$, p. 95-112. GEAP, Porto

Delatte, A. e Derchain, Ph. (1964), Les Intailles Magiques grées-égyptiennes. Bibliothéque Nationale. Paris

FrançA, Elsa A. (1969), "Anéis, braceletes e brincos de Conimbriga". Conimbriga, vol. VIII, p. 17-43. Coimbra

Conimbriga, A0 (2001) 141-197 
FurtwAngler, Adolf (1900), Die Antiken Gemmen (Geschichte Der Steinschneidekunst im Klassischen Altertum). Ed. de 1964 (vol. I) e 1965 (vol. II e III). Amsterdam-Osnabrueck, 1964-1965

Gauthier, Marc (1977), "Circonscription d'Aquitaine . Gallia, tomo 35, Fase. 2, p. 449-472. Ed. CNRS, Paris

GesZTelyi, Tamás (1987), A Déri Múzeum Gemmagyujteménye. Debrecen

Goldscheider, L. (1940), Roman Portraits. Phaidon Edition, Oxford. Univ. Press.

New York. Harrison \& Sons Ltd, Londres

GONZENBACH, Victorine von (1952), Romische Gemmen aus Vindonissa.

Gramatopol, Mihai (1974), "Les pierres gravées du Cabinet numismatique de l'Académie Roumaine”. Latomus, vol. 138. Bruxelas

Grimal, Pierre (1992), Dicionário da Mitologia Grega e Romana, 2a edição. DIFEL, Oeiras, 1992 •

Guiraud, Hélène (1974), "Intailles du Musée de Bourges". Revue Archéologique du Centre, tomo XIII, fase. 34 , p. 219-228

GuIRAud, Hélène (1988), Intailles et Camées de VÉpoque Romaine en Gaule (Territoire Français). $48 .^{\circ}$ suplemento da Gallia. Ed. CNRS, Paris

Guiraud, Hélène (1996), "Intailles de Lons-le-Saunier (Jura)". Gallia, tomo 52, p. 359-406. Ed. CNRS, Paris

Guiraud, Hélène (1996), Intailles et Camées Romains. Paris

Guiraud, Hélène (1998), Intailles du Musée des Antiquités Nationales. Antiquités Nationales, 30, 1998

HAMBURger, Anit (1968). Gems from Caesarea Maritima. ATIQOT (english series), vol. VIII. Jerusalém

Hautecoeur, M. L. (1910), Catalogue des Musées et Collections Archéologiques de VAlgérie et de la Tunisie: Musée Alaoui (Suppi.). Paris

HENIG, Martin (1974), A Corpus of Roman Engraved Gemstones from British Sites. Part II - Catalogue and Plates. B.A.R. 8 (II)

HenIG, Martin (1975), The Levis Collection of Engraved Gemstones in Corpus Christi College, Cambridge. B.A.R. Supplementary Series, I

Henig, Martin e Whiting, Mary (1987), Engraved Gems from Gadara in Jordan - The Sad Collection of Intaglios and Cameos. Oxford University Committee for Archaeology, n. ${ }^{\circ}$ 6. Oxford

HERFORT-KoCH (1988), "Schmuck und Gemmen im Museum für Kunst und Kulturgeschichte des Stadt Dortmund". Boreas, vol. 11, p. 265-300

HÜBNER, Aemilius (1892), Inscriptionum Hispaniae Latinarum (Corpus Inscriptionum Latinarum). Supplementus. Berlim

ImHoof-Blumer, Friedrich e Keller, Otto (1972), Tier-und Pflanzenbilder auf Münzen und Gemmen des Klassischen Altertums. Hildesheim

JoHns, Catherine (1997), The Snettisham Roman Jeweller s Hoard. British Museum Press. Londres

KrUG, Antje von (1975), "Romische Gemmen und Fingerringe im Museum für Vorund Frühgeschichte Frankfurt a. M". Germania, 53, 12, p. 113-119. Frankfurt

KrUG, Antje von (1978), "Romische Fundgemmen". Germania, 56,2, p. 476-503. Berlim 
KRUG, Antje von (1980), Antike Gemmen im Rõmisch-Germanischen Museum Kôln. Bericht der Rõmisch-Germanischen Kommission, 61, p. 151-260, est. 64-137 LiPPOLD, George (1922), Gemmen und Rameen des Altertums und der Neuzeit. Stuttgart

LOPEZ De la Orden, María Dolores (1989), "Colección Glíptica del Palacio de la Condessa de Lebrija (Sevilla)". Boletín del Seminario de Estudios de Arte y Arqueología, LV, p. 246-272. Valladolid

Lopez de la Orden, María Dolores (s.d.), La Gliptica de la Antiguidad en Andalucía. Universidade de Cadiz

Luzon, J. M. (1982), “Entallos Romanos del Museo de Merida”. In Homenaje a Saenz de Buruaga, p. 127-135. Madrid

MaASKAnT-KLEIBrinK, Marianne (1978), Catalogue of the Engraved Gems in the Royal Coin Cabinet - The Hague. The Greek, Etruscan and Roman Collections. Haia

MAIOLI, Maria Grazia (1971), "Gemme della Collezione Rasponi nel Museo Nazionale di Ravenna”. Felix Ravenna, Fase. II, p. 359. Ravenna

MANDEL-Elzinga, Ursula (1985), "Eine Gemmensammlung aus Alexandria im Akademischen Kunstmuseum der Universitát Bonn”. Bonner Jahrbucher, vol. 185, p. 243-298. Bona

Marshall, F. H. (1907), Catalogue of the Finger Rings Greek, Etruscan and Roman in the Departments of Antiquities. British Museum. Londres

Medenbach, Olaf e SussiecK-Fornefeld, Cornelia (1982), Minerais. Edição portuguesa do original alemão "Mineralien". Munique. Tradução Portuguesa por Editorial Pública. Lisboa, 1983

Merlin, A. e Lantier, B. (1922), Catalogue des Musées et Collections Archéologiques de TAlgérie et de la Tunisie. Musée Alaoui (2 éme Suppl.). Paris

Middleton, J. Henry (1969), Ancient Gems - The Engraved Gems of Classical Times. Argonaut, Inc. Publishers. Chicago

MidDleton, Sheila Hoey (1991), Engraved Gems from Dalmatia. Oxford University Committee for Archaeology, n. ${ }^{\circ} 31$. Oxford

Neverov, O. (1976), Antique Intaglios in the Hermitage Collection. Aurora Art Publishers. Leninegrad

Neverov, O. (1988), Antique Cameos in the Hermitage Collection. Leninegrad

PAÇO, Afonso do e Lemos, João de (1966), "Dr. Bairrão Oleiro - A propósito do seu Ex-Libris”. Boletim da Academia Portuguesa de Ex-Libris, n. ${ }^{\circ} 37$. Braga

Popovic, Ivana (1989), Les Camées Romains au Musée National de Beograd. Antiquité V. Beograd

REINACH, Salomon (1895), Pierres Gravées des collections Marlborough et d'Orléans. Paris

Richter, Gisela (1948), Roman Portraits. New York

Richter, Gisela (1956), Catalogue of Engraved Gems, Greek, Etruscan and Roman. Metropolitan Museum of Art. New York. L'ERMA, Roma

RICHTER, Gisela (1971), Engraved Gems of the Romans - a supplement to the History of Roman Art (The Engraved Gems of the Greeks, Etruscans and Romans) part II. Phaidon Press, Ltd. Londres

Conimbriga, 40 (2001) 141-197 
Righetti, Romulo (1955). Gemme e Cammei delle Collezioni Comunali. Roma

Ruseva-Slokoska, Ljudmila (1991), Roman Jewellery. A Collection of the National Archaeological Museum. Sofia. Publishing House on the Bulgarian Academy of Sciences. Sofia

SÁenz de Buruaga, J. A. (1946), "Museo Arqueológico de Mérida (Badajoz)”. Memorias de los Museos Arqueológicos Provinciales, vol. VI, 1945. Madrid

Sena Chies A, Gemma (1966), Gemme del Museo Nazionale di Aquileia (Testo e Tavole). Padova

Sena Chiesa, Gemma (1978), "Gemme di Luni”. Archaelogica 4. Roma

SousA, J. J. Rigaud de (1973), “Anéis e Entalhes da Zona Portuguesa do Convento Bracaraugustano”. Cuadernos de Estudios Gallegos, tomo XXVIII, 85, p. 188-192.

Santiago de Compostela

SPIER, Jeffrey (1992), Ancient Gems and Finger Rings - Catalogue of the Collections. The J. Paul Getty Museum. Malibu - California

SternBERG, Frank (1980), Antike Miinzen - Gemmen. Zurich

Stevenson, F. S. A. (1964), Dictionary of Roman Coins. B. A. SeABy, Ltd. Londres STUPPERICH, Reinard (1988). "Ein Goldarmband mit dreizehn rõmischen Gemmen in Münster”. Boreas, 11, p. 292-300

Sutherland, C.H.V. (1974), Monnaies Romaines. Office du Livre. Fribourg

Tamma, Giuseppina (1991), Le Gemme del Museo Archeologico di Bari. Bari

Toynbee, J. M. C. (1973), Animals in Roman Life and Art. Thames and Hudson. Londres

VollenweIDER, Marie-Louise (1972), Die Portratgemmen der rõmischen Republik. Mainz am Rhein

Walters, H. B. (1926), Catalogue of the Engraved Gems and Cameos in the British Museum. Londres

Zazoff, Peter (1965), Gemmen in Kassel. Archaologischer Anzeiger, Heft 1. Berlim ZWIERLEIN-DIEHL, Erika (1991), Die Antiken Gemmen des Kunsthistorischen Museums in Wien, vol. III. Munique

Dictionnaire Des AntiQuitées Romaines et GReCQues (dir. de Anthony Rich) - tradução francesa do original inglês, sob a direcção de M. Chéruel. Ed. Firmin Didot Frères, Fils et Ca. Paris, 1861, p. 35 - artigo "annulus ou anulus". Idem, Ed. Grande Bibliotèque Payot, Paris, 1995, p. 35-36, artigo "annulus ou anulus"

Totius Latinitatis OnOmasticon (direcção de Vincent De-Vit). Ed. Prati, vol. I (1858), vol. II (1873), vol. III (1882).

Conimbriga, 40 (2001) 141-197 
EST. I

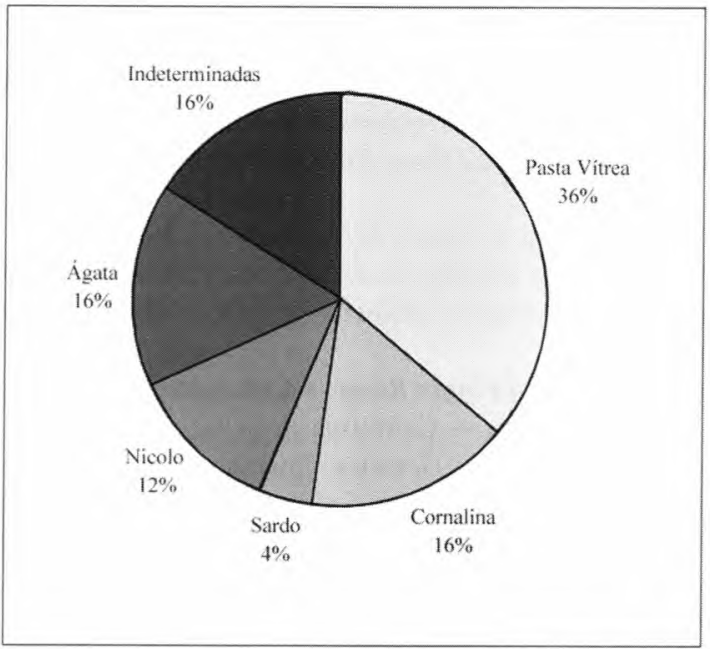

Natureza

Pasta vitrea 9

Cornalina 4

Sardo 1

Ágata

Indeterminadas 4

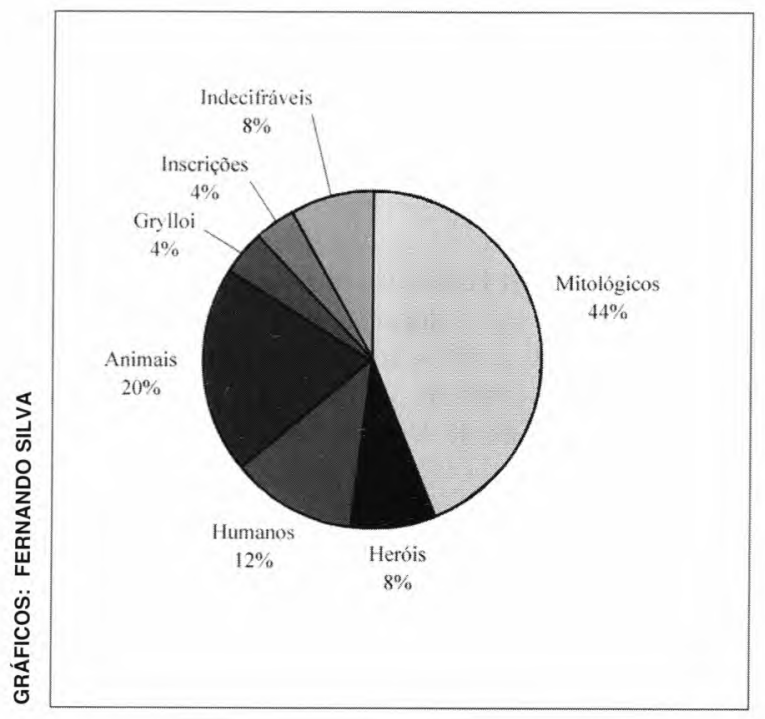

Temas

Mitológicos

Heróis

Humanos

Animais

Grylloi

Inscriçoes

Indecifráveis 2 
EST. II
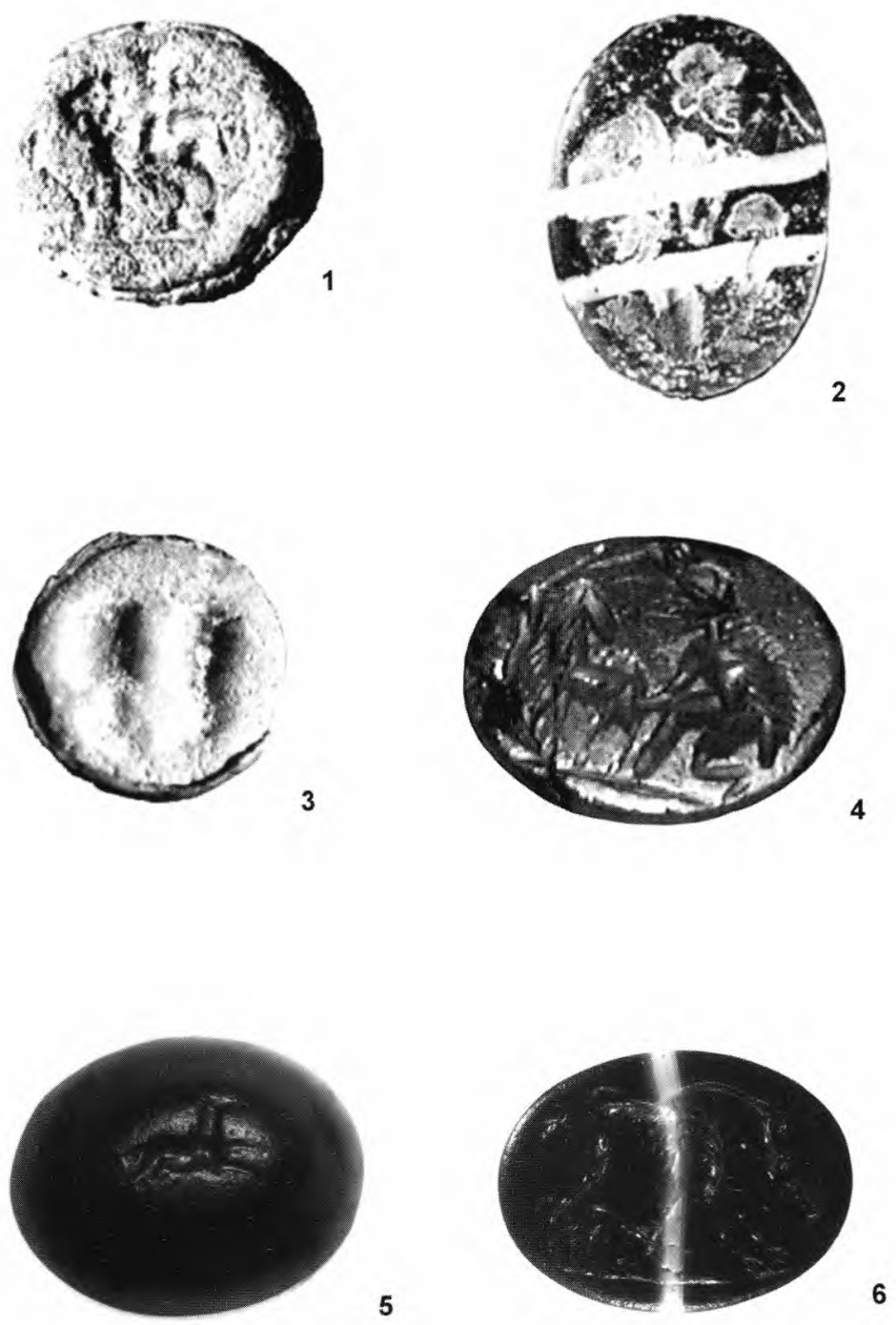
EST. Ill
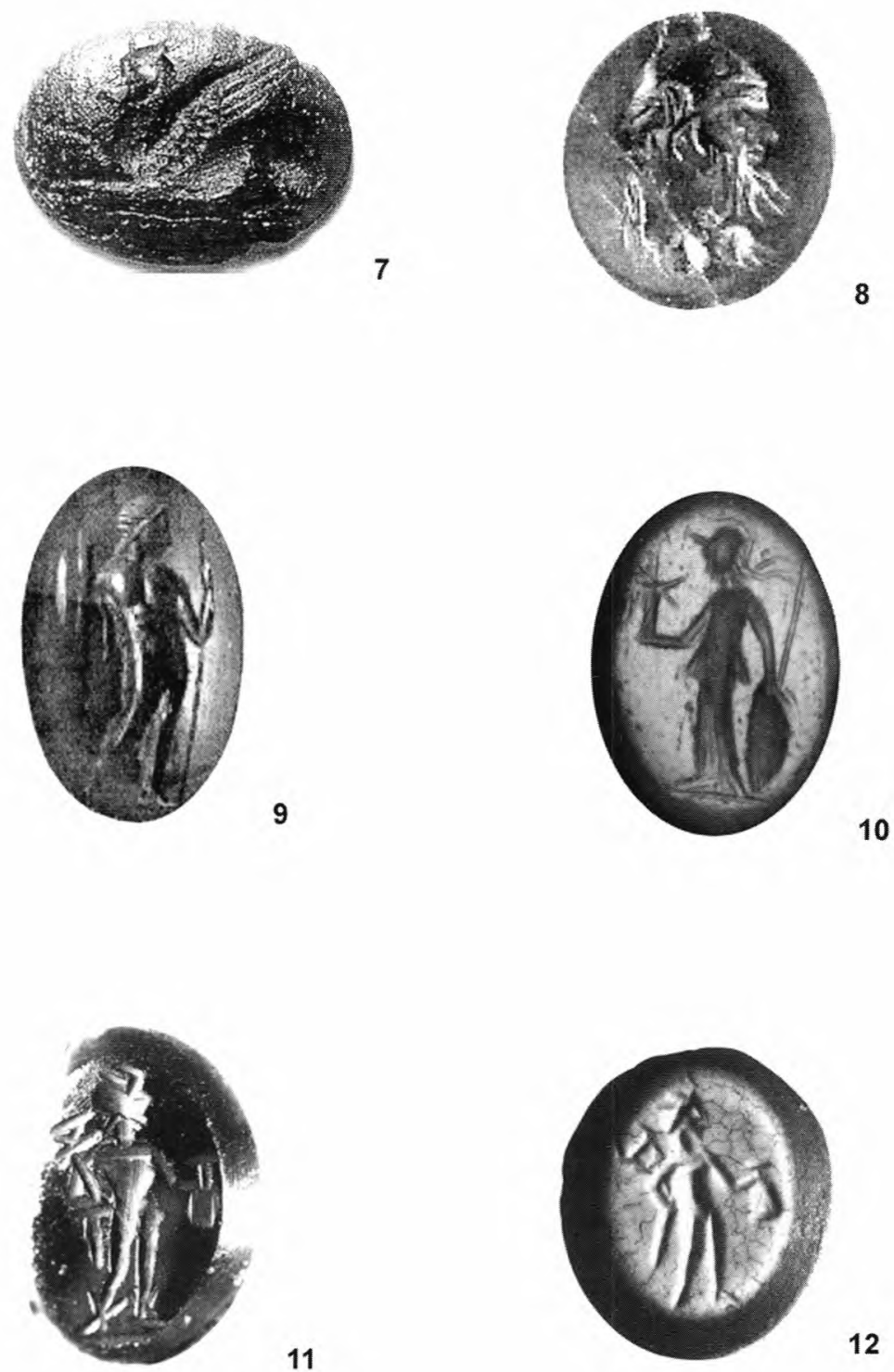

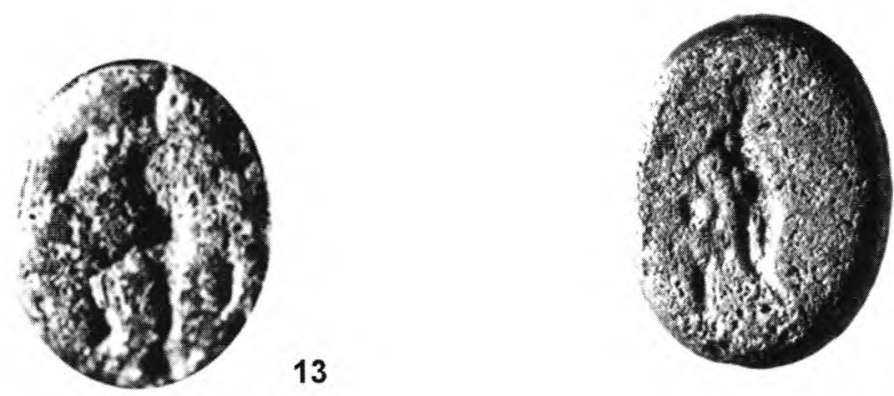

14
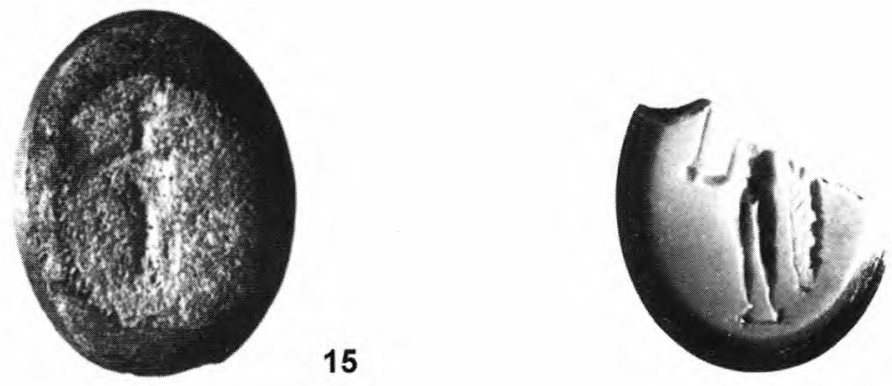

16
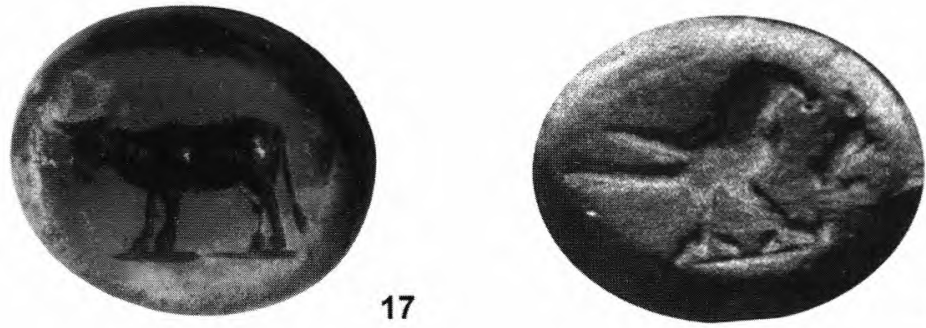

18 

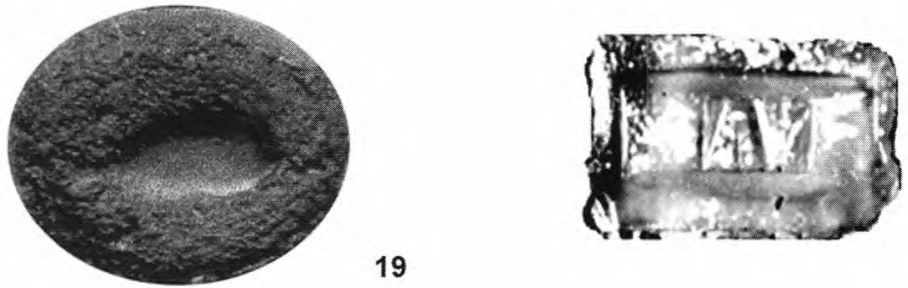

19
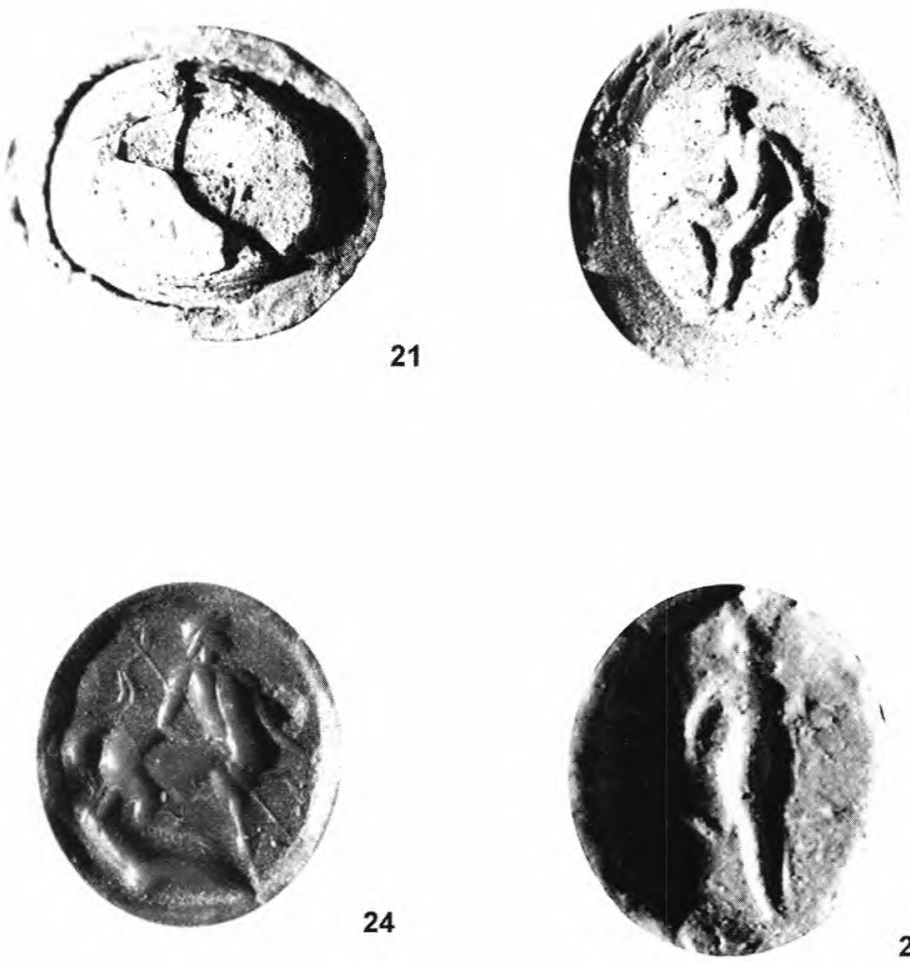